\title{
WEALTH DESTRUCTION EFFECTS OF ANNUAL MANAGEMENT FORECASTS
}

\author{
by
}

Md. Mahafuzur Rahaman Chy

A thesis submitted in conformity with the requirements

for the degree of Doctor of Philosophy

Joseph L. Rotman School of Management

University of Toronto

(C) Copyright 2018 by Md. Mahafuzur Rahaman Chy 


\begin{abstract}
Wealth Destruction Effects of Annual Management Forecasts
\end{abstract}

\author{
Md. Mahafuzur Rahaman Chy \\ Doctor of Philosophy \\ Joseph L. Rotman School of Management \\ University of Toronto
}

2018

Exploiting exogenous variations in annual earnings guidance, I find evidence that an increase in annual guidance leads managers to engage in more short-term oriented actions. Specifically, I find that relative to firms that do not provide annual earnings guidance, firms that provide annual guidance decrease SGA expenses, R\&D expenditures, and capital expenditures significantly in an attempt to meet earnings targets set by their own forecasts. The investment cuts help firms avoid missing earnings guidance but subsequently result in a gradual decline in firm growth, reduction in innovation activities, and long-term shareholder value destruction. I provide several pieces of mutually corroborating evidence that suggest an alternative mechanism other than earnings guidance is unlikely to drive the results. The findings have implications for firm strategy, policy-making, and academic research on management forecast accuracy. 


\section{Acknowledgements}

I express immense gratitude to my supervisors, Jeffrey Callen and Partha Mohanram, for patiently guiding me throughout the doctoral studies as well as for all academic and emotional support. I thank Francesco Bova and Baohua Xin, members of my dissertation committee, for their guidance and support.

I also thank Peter Cziraki, Gus De Franco, Alex Edwards, Moqi Groen-Xu, OleKristian Hope, Pervin Shroff (external examiner), Dushyantkumar Vyas, and Ping Zhang for their suggestions and counsel. My fellow PhD students Muhammad Azim, Stephanie Cheng, Ross Lu, Michael Marin, Barbara Su, Jingjing Wang, Mingyue Zhang, and Wuyang Zhao deserve thanks for keeping me motivated throughout the PhD studies at Rotman.

Finally, I am forever indebted to my wife, Fathmin, and family members including my parents, elder brother, and grandparents for their love, patience, prayers, and encouragement during my doctoral studies. 


\section{Table of Contents}

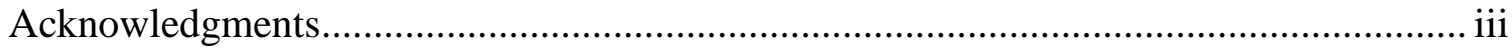

Table of Contents..........................................................

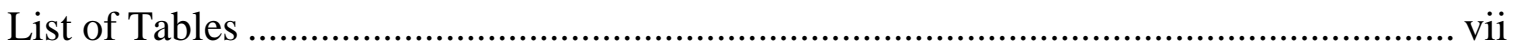

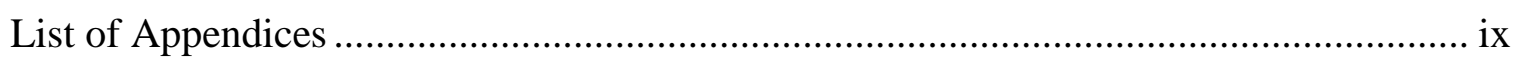

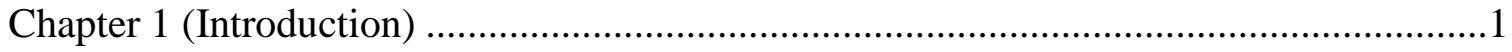

Chapter 2 (Literature and Hypothesis) ................................................................ 10

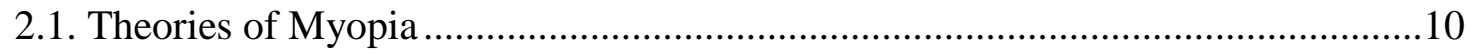

2.2. Earnings Guidance and the Manifestation of Myopia........................................11

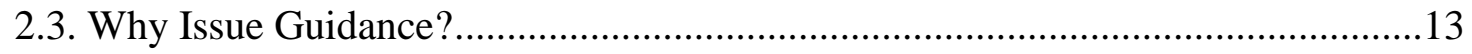

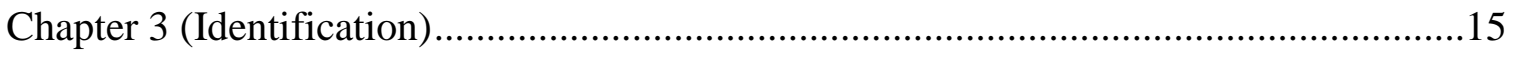

3.1. Endogeneity of Earnings Guidance ....................................................... 15

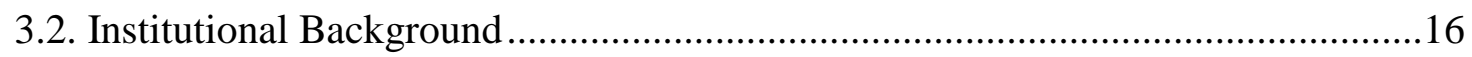

3.3. How IDD Affects Management Forecasts ..................................................... 17

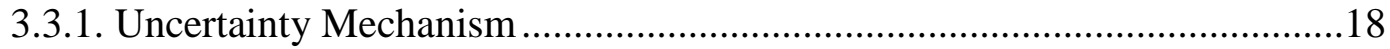

3.3.2. Employee Rent Extraction Mechanism .............................................. 19

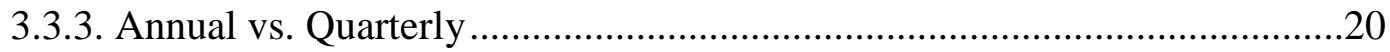

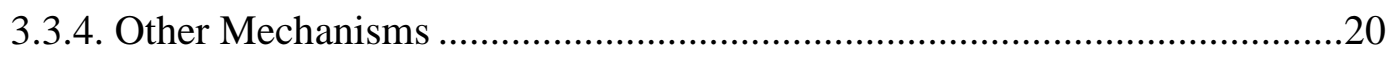

Chapter 4 (Data, Variables, and Research Design) ....................................................21

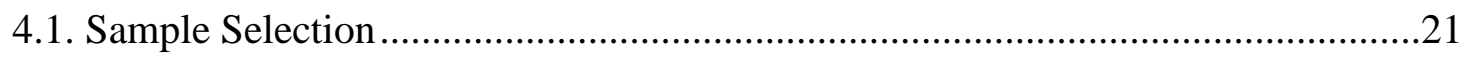

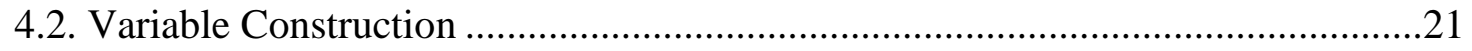

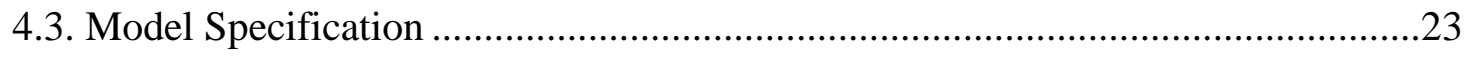

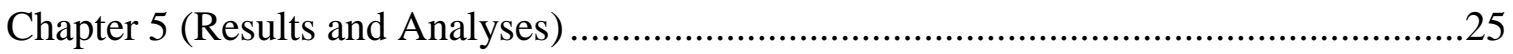




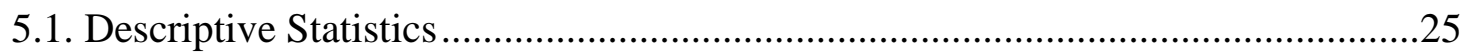

5.2. Analyses of the First Stage: State Adoption of IDD and Management Forecasts .25

5.3. Main Results: Annual Earnings Guidance and Myopic Underinvestment ............27

Chapter 6 (Consequences of Managerial Myopia) ………………………………............31

Chapter 7 (Evidence on the Exclusion Restriction) ..........................................................33

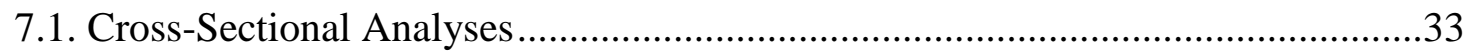

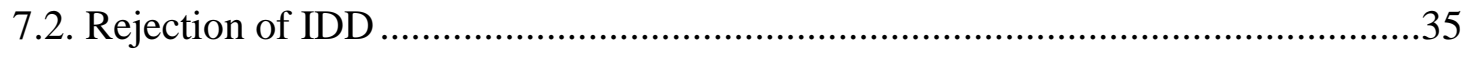

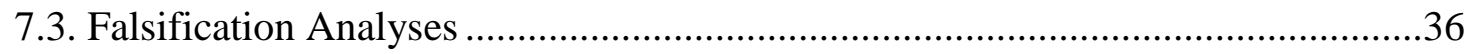

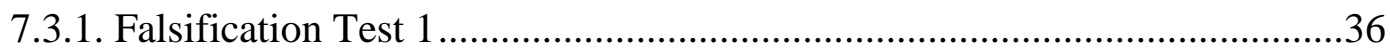

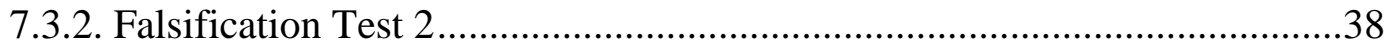

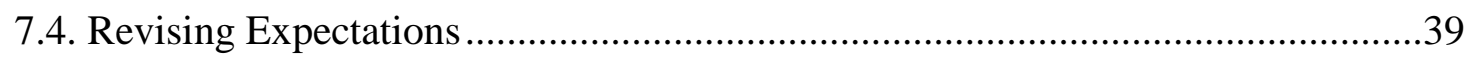

7.5. Does Myopic Underinvestment Help Firms Meet or Beat Earnings Guidance? ...40

Chapter 8 (Testing Altenative Mechanisms) .................................................................41

8.1. Executive Compensation Structure and Risk-taking Incentives ............................41

8.2. Barrier to Entry/Competitive Pressure ..............................................................42

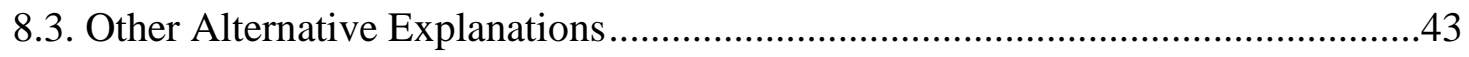

Chapter 9 (Earnings Guidance and Accruals Earnings Management)...............................47

Chapter 10 (Asymptotic Bias of IV Estimation).............................................................49

Chapter 11 (Conclusion) ............................................................................................52

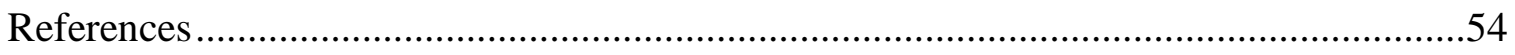

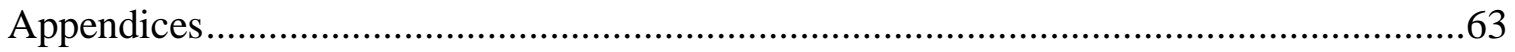

Appendix A: Inevitable Disclosure Doctrine Adoption/Rejection ................................63

Appendix B: Key Variable Definitions.....................................................................65 


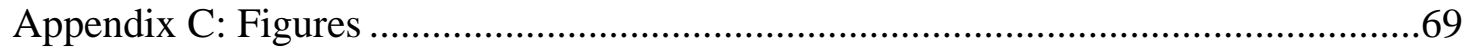

Figure 1: Time-series evolution of annual and quarterly management earnings

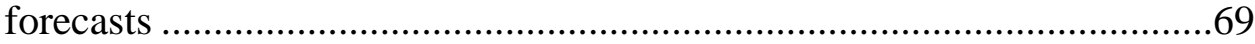

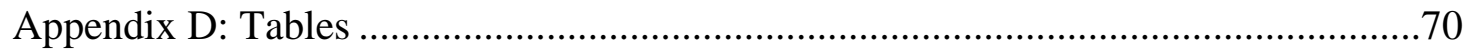




\section{List of Tables}

Table 1-A: Summary Statistics for Key Variables ............................................................ 70

Table 1-B: Correlation Matrix of Key Variables .......................................................... 71

Table 2: 2SLS First Stage - IDD and Management Earnings Guidance.............................. 72

Table 3: The Effects of IDD on Guidance Precision and Timeliness ................................. 74

Table 4-A: Main Results - Earnings Guidance Frequency and Managerial Myopia............. 76

Table 4-B: Main Results - Earnings Guidance Incidence and Managerial Myopia .............. 77

Table 4-C: Main Results - Earnings Guidance and Myopia (Reduced Form)...................... 78

Table 5-A: Sensitivity to Clustering Choices - State Clustering ..................................... 80

Table 5-B: Sensitivity to Clustering Choices - State-Year Clustering ............................... 81

Table 5-C: Sensitivity to Clustering Choices - Firm and State-Year Clustering .................. 82

Table 6-A: Consequences of Myopia - Revenue Growth ............................................. 84

Table 6-B: Consequences of Myopia - Innovation as Measured by Patents........................ 85

Table 6-C: Consequences of Myopia - Innovation as Measured by Citations ...................... 86

Table 6-D: Consequences of Myopia - Evolution of Stock Returns .................................. 87

Table 7-A: Cross-Sectional Variations in the Effect of IDD on Earnings Forecasts............. 89

Table 7-B: Cross-Sectional Variations in the Effect of IDD on Investment ....................... 90

Table 8: The Effects of Rejection of IDD on Guidance and Myopic Underinvestment......... 92

Table 9-A: Falsification Test 1 - IDD and Guidance (Sample Period: 1980-1990) ............. 94

Table 9-B: Falsification Test 1 - IDD and Investments (Sample Period: 1980-1990).......... 95 
Table 10: Falsification Test 2 - IDD and Investments of SEC-registered Private Firms ....... 97

Table 11-A: Guidance to Revise Down Expectations and Investments ............................. 99

Table 11-B: Guidance to Revise Up or Confirm Expectations and Investment .................. 100

Table 12: Does Myopic Underinvestment Help Firms Meet or Beat Earnings Guidance?.. 102

Table 13-A: Alternative Explanations - Compensation and Risk-Taking Incentives.......... 104

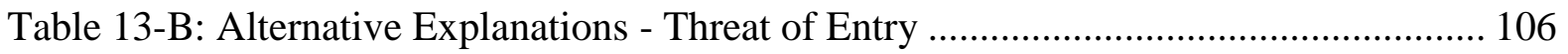

Table 13-C: Alternative Explanations - CEO Career Concerns ......................................... 108

Table 13-D1: Alternative Explanations - Investment Opportunity Decreases .................... 110

Table 13-D2: Alternative Explanations - Investment Opportunity Increases...................... 112

Table 14: Sensitivity of Inferences to Potentially Endogenous Control Variables .............. 114

Table 15: Sensitivity of Inferences to Industry and Local Economic Shocks .................... 116

Table 16: Earnings Guidance and Accruals Earnings Management.................................. 118 


\section{List of Appendices}

Appendix A: Inevitable Disclosure Doctrine Adoption/Rejection .............................59

Appendix B: Key Variable Definitions .........................................................61

Appendix C: Figure 1: Time-series evolution management earnings forecasts .........63

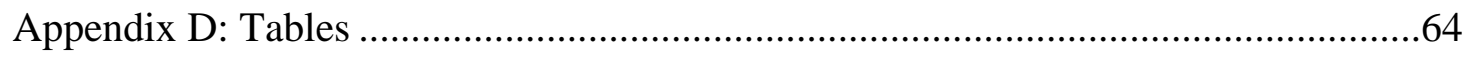




\section{Chapter 1}

\section{Introduction}

Critics often argue that the practice of issuing earnings guidance exacerbates managerial myopia (Graham, Harvey, and Rajgopal 2005; Houston, Lev, and Tucker 2010; Chen, Matsumoto, and Rajgopal 2011). Theoretical studies also imply that, even in an efficient market, managers may engage in short-term oriented actions to meet current earnings targets (see Chapter 2). Intuitively, because missing earnings guidance could lead to precipitous price declines, damage managerial reputation, and/or attract unfavorable media attention, managers may prioritize meeting earnings guidance even if doing so necessitates cutting long-term investments such as R\&D and capital expenditures.

In this thesis, I examine the link between earnings guidance and managerial shorttermism. My empirical analyses focus mainly on annual earnings guidance. Figure 1 shows that while until the early 2000s quarterly earnings guidance was more numerous, annual earnings guidance has outnumbered quarterly guidance since then. Recent survey evidence also suggests that $67 \%$ of the firms surveyed provide annual earnings guidance whereas only 29\% provide quarterly guidance (NIRI Analytics 2016). This increase in annual guidance could at least partly be attributed to some managers' and practitioners' belief that annual earnings guidance is less subject to myopia concerns. For instance, the U.S. Chamber of Commerce 
(2007) recommends moving away from quarterly guidance to annual guidance as a means to tackle short-termism. Some managers also agree with this recommendation. Houston et al. (2010) investigate firms that stop providing quarterly guidance citing a change of focus to longterm goals; but of the 222 firms they examine, $86 \%$ continued to provide annual guidance, consistent with the conjecture that these firms believe annual guidance does not impede longterm focus. Karageorgiou and Serafeim (2014) remark, "we observe companies shifting from quarterly earnings guidance to annual guidance as they realize the costs of very short-term targets."

Given this backdrop, I ask the following research question: Does the practice of issuing annual earnings guidance exacerbate or mitigate managerial myopia? Because the decision to issue earnings guidance is voluntary and therefore endogenous, I use the staggered adoption of Inevitable Disclosure Doctrine (IDD) by several states in the U.S. as a means of identification under instrumental variable (IV) regression approach. When a state court adopts IDD, firms in that state can bar employees who possess important trade secrets from working for a competitor if such employment could inevitably lead to the disclosure of trade secrets to the competitor (Klasa et al. 2017). As I discuss below, the state adoption of IDD generates large exogenous variations in annual earnings guidance but does not affect quarterly guidance. Further, several pieces of mutually corroborating evidence suggest that an alternative mechanism other than annual earnings guidance is unlikely to be driving the results.

The adoption of IDD reduces operational uncertainty by reducing uncertainty about key production inputs, labor and knowledge capital. Prior studies find that managers are more likely to provide earnings guidance when uncertainty declines (Waymire 1985; Bozanic, Roulstone, and Van Buskirk 2015; Lin, Wei, and Wu 2016). A reduction in operational 
uncertainty makes it easier for managers to predict future earnings more accurately and precisely. Because issuing guidance requires them to predict future earnings, managers frequently cite "uncertainty" as a key reason for suspending or stopping earnings guidance (Houston et al. 2010; Chen et al. 2011). IDD reduces input uncertainty by lessening the risk of trade-secret theft and improving the chances of employee retention. Firms' $10-\mathrm{K}$ disclosures reveal that the risk of employee turnover and trade-secret divulgence introduces significant unpredictability into the earnings process (Eisfeldt and Papanikolaou 2013; Glaeser 2017). As such, managers may be more willing to issue earnings guidance following the state adoption of IDD.

Further, because IDD reduces the bargaining power of key employees, it lowers the likelihood that they will use earnings projections as negotiation leverage to extract rents. Firms have a greater incentive to provide earnings forecasts when the proprietary cost in the form of employee rent extraction threat declines (Verrecchia 1983; Kleiner and Bouillon 1988; Hilary 2006; Chung et al. 2015; Bova, Dou, and Hope 2015). Revealing information about future performance reduces managers' option value of manipulating information to gain an advantage in the wage-bargaining process. Verrecchia (1983) specifically cites the example of wage negotiations at Chrysler, wherein employees demanded pay raises after the chairman declared that the firm's prospects had improved. Similarly, in 2005, General Motors Corporation suspended its annual earnings guidance in anticipation of wage negotiations (Bova et al. 2015).

Consistent with these mechanisms that reduce the disclosure thresholds for earnings guidance, I find a marked increase in the likelihood and frequency of numerical annual earnings guidance by firms located in states that adopt IDD (treatment firms) relative to firms located in other states (control firms). Specifically, I find that treatment firms provide 
approximately $36 \%$ more annual forecasts than control firms do following the state adoption of IDD. The statistical significance of these effects is large, mitigating concerns about the weak instrument problem. Further, consistent with IDD reducing earnings uncertainty, firms issue more precise and timelier annual guidance. Notably, I do not observe any discernible changes in quarterly guidance releases following the state adoption of IDD, which is consistent with less earnings uncertainty and lower proprietary costs associated with quarterly guidance. ${ }^{1}$

Following prior literature, I use Selling, General, and Administrative (SGA) expenses (including advertising expenses), research and development (R\&D) expenditures, and capital expenditure (CAPEX) as proxies for managerial myopia (Graham et al. 2005; Houston et al. 2010). SGA expenses and R\&D expenditures bring uncertain benefits in future periods, but they enter as expenses in the current period's income statement, thereby reducing managers' ability to meet the current period targets set through earnings guidance. While capital expenditures do not directly enter the income statement as expenses, depreciation and attendant costs, such as labor, financing, leasing, and other start-up charges, still reduce managers' ability to meet the current period earnings targets (Graham et al. 2005; Asker et al. 2015; Kraft et al. 2016).

Exploiting within-firm exogenous variations in annual earnings guidance induced by IDD under the IV regression approach, I find that increases in numerical annual forecasts lead to statistically significant declines in SGA, R\&D, and CAPEX. Specifically, a representative

\footnotetext{
${ }^{1}$ Because annual forecasts have a longer time lag prior to earnings realization, earnings unpredictability is more salient for annual forecasts than quarterly forecasts. Further, proprietary costs are likely to be higher for annual guidance because it allows a significant amount of time for strategic reaction (see Chapter 3). That IDD does not affect quarterly guidance is helpful because it allows me to derive IV estimates for the effect of annual guidance on managerial myopia without the estimates being contaminated by simultaneous changes in quarterly guidance.
} 
firm that issues annual guidance invests $3.8 \%, 1.25 \%$, and $0.94 \%$ (of assets) less in SGA, R\&D, and CAPEX respectively, relative to firms that do not provide annual guidance. Given that the mean investment levels in SGA, R\&D, and CAPEX in the sample are 33\%, 6.5\%, and 5.7\% of assets respectively, the retrenchment in investments owing to annual guidance is economically significant.

The investment cuts are not a reduction in overinvestment owing to improved transparency (investment efficiency hypothesis). I find that firms that reduce investments are more likely to meet or barely beat annual earnings targets set by their own forecasts. The investment cuts result in a gradual decline in firms' revenue growth, innovation activities (a measure of R\&D investment efficiency), and stock market valuation. Further, the crosssectional patterns in the investment reduction and results based on exogenous changes in investment opportunity sets are consistent with the managerial myopia hypothesis and inconsistent with the investment efficiency hypothesis.

To sharpen the causal inferences, I show that the cross-sectional variations in the effect of IDD on myopic underinvestment predictably follow the cross-sectional variations in the effect of IDD on annual earnings guidance. Specifically, the effect of IDD on annual guidance is more pronounced when: (i) firms are more likely to possess trade secrets; (ii) earnings uncertainty is higher; (iii) the employee rent extraction threat is more credible; (iv) investor demand for earnings guidance is higher; and (v) CEO tenure is shorter. Correspondingly, the effect of IDD on myopic underinvestment is also stronger for the same cross-section of firms.

The treatment effect is symmetric in that when states reject IDD after having previously adopted it, firms issue fewer earnings forecasts. Consequently, firm investments also increase. In addition, for firms that revise expectations down with pessimistic forecasts, myopic 
underinvestment is less pronounced. These patterns support a causal interpretation.

It is difficult to reconcile an alternative explanation with the predictable cross-sectional and time-series patterns in the treatment effects of IDD on annual guidance and consequent myopic underinvestment. Nonetheless, I provide additional evidence to demonstrate that changes in managerial compensation structure, risk-taking incentives, the threat of productmarket entry, managerial career concerns, contemporaneous local and industry shocks, or human capital investment incentives do not explain the myopic underinvestment that IDD induces.

Importantly, falsification analyses reveal that whereas IDD adversely affects investments when firms issue more annual guidance, it encourages more investments when the guidance channel is shut down. To elaborate, the retention of key employees helps firms reap greater benefits from employee training and investment in organizational capital (i.e., SGA expenses). Similarly, continued employment of scientists and engineers, as well as the protection of proprietary information, allows firms to internalize returns from $R \& D$ and CAPEX. Therefore, I predict — consistent with prior evidence in the economics and finance literatures (e.g., Autor, Kerr, and Kugler 2007; Jeffers 2016) — that, in the absence of its effect through earnings guidance, IDD would encourage firms to make greater investments in SGA, R\&D, and CAPEX.

To test the above prediction, I conduct two sets of falsification tests. In the first falsification test, I exploit the state adoption of IDD in the 1980s when firms rarely provided management forecasts due to the high litigation costs associated with issuing forward-looking statements (Securities and Exchange Commission 1994; Skinner 1995). I hand-collect all management forecast data from Factiva for a sample of treatment firms in states that adopted 
IDD in the 1980s as well as for a control group of firms that are located next to the IDDadopting states. I find that IDD does not affect management guidance in this period, implying that litigation concerns outweigh the incentives that IDD provides to issue earnings guidance in this falsification period. However, firms invest significantly more in response to the increased trade-secret protection and employee retention afforded by IDD.

A concern with the above falsification test is that the sample period (1980-1990) is different from the main sample period (1994-2011). As a result, local economic shocks and industry factors that are different in the two sample periods may drive the results. To further mitigate this concern, I examine how IDD affects the investments of firms with public debt but no public equity as well as large private firms that are subject to the same SEC filing requirements as the treatment firms. These firms are exposed to the same local and industrial economic conditions as the treatment firms in the main sample but are free from equity market pressures induced by earnings guidance. Consistent with the first falsification test, I find modest evidence that these firms also increase investments following the state adoption of IDD.

If an alternative mechanism other than earnings guidance drives the adverse effects of IDD on firm investments, then one would observe similar adverse effects of IDD on investments when the guidance mechanism is shut down. However, two falsification tests involving different sample periods and different sample of firms suggest that it is unlikely another factor drives the results. I also derive the asymptotic biases of the IV estimation. Relying on the innocuous assumption that all economic rents converge to zero in a perfectly competitive market, I show that IDD, as an instrument for earnings guidance, is asymptotically unbiased. 
This study makes several contributions. First, several prior studies investigate whether quarterly earnings guidance exacerbates managerial myopia (see Chapter 2 ). ${ }^{2}$ Summarizing the evidence in these studies, Call et al. (2015) remark, "At the minimum, the collective evidence does not support the view that guidance fosters managerial myopia." In contrast, I provide evidence that annual earnings guidance induce managers to engage in myopic underinvestment. That some practitioners believe annual guidance could mitigate managerial myopia makes the findings more relevant. To reconcile my evidence with prior studies, note that annual guidance has a long horizon within which unanticipated shocks could occur limiting managers' ability to meet earnings guidance. Further, investment irreversibility is a less binding constraint within the annual guidance horizon. In contrast, quarterly earnings guidance has a much shorter horizon and is often used to revise market expectations downwards (see Chapter 2). In addition, investment tends to be irreversible over a short horizon (quarterly guidance). These factors could potentially explain why prior studies do not observe a robust link between quarterly guidance and managerial myopia.

Second, the findings are informative because whether guidance affects myopia is far from obvious ex-ante. To the extent that earnings guidance as a form of voluntary disclosure improves transparency (Coller and Yohn 1997; Balakrishnan et al. 2014), better monitoring would likely curb investment inefficiency. If earnings guidance reduces the cost of capital (Baginski and Rakow 2012), then firms may even make more investments.

Third, the findings also suggest that more accurate earnings guidance may not

\footnotetext{
2 Most prior studies focus on the link between quarterly earnings guidance and managerial short-termism because practitioner criticisms of guidance practice focus primarily on quarterly earnings guidance (Houston et al. 2010).
} 
necessarily indicate better forecasting ability of managers. Rather, improved accuracy could potentially be a result of myopic underinvestment, which has implications for academic research on management forecast accuracy.

Finally, the study contributes to the expanding literature on real effects of accounting. The evidence suggests that earnings guidance could potentially induce adverse real effects in the form of distortionary investment behavior. As such, this thesis has implications for policymakers and practitioners in balancing the costs and benefits of earnings guidance as a form of voluntary disclosure. 


\section{Chapter 2}

\section{Literature and Hypothesis}

\subsection{Theories of Myopia}

Theories of managerial myopia suggest that faced with information asymmetry, investors may demand information about accounting earnings (such as earnings guidance) to make inferences about firm value and managerial ability (Gigler et al. 2014; Narayanan 1985; Stein 1988; Stein 1989; Stein 2003). This may incentivize managers to focus on short-term earnings at the expense of long-term investments. As a result, one may observe short-termism even in efficient markets (Stein 1989; Stein 2003).

Edmans, Heinle, and Huang (2016) show that disclosing more hard information, such as earnings forecasts, may improve transparency but that the practice encourages managers to prioritize hard measures of performance, such as earnings, by sacrificing intangible investment. In Edmans et al. (2016), because earnings guidance induces myopic underinvestment, the optimal disclosure policy would be to not provide earnings forecasts. However, Edmans et al. (2016) contend that a manager cannot commit to non-disclosure because "he may be unable to implement it as he will opportunistically increase disclosure precision if he knows that the signal is likely to be good."

Stein (1989) shows that rational managers will engage in myopic underinvestment to 
inflate current earnings if investors are fixated on current earnings. Fischer and Verrecchia (2000) extend Stein (1989) to show that when there is sufficient uncertainty about managers' objectives, market participants cannot completely unbias reported earnings, and managers may be better off by engaging in earnings management. The intuition from Stein (1989) and Fischer and Verrecchia (2000) may apply to the case of earnings guidance in the sense that earnings guidance is simply the earnings announcement brought forward with some bias/error.

\subsection{Earnings Guidance and the Manifestation of Myopia}

To understand how myopia may manifest, note that discretionary expenditures such as $R \& D$ and SGA are recorded in the income statement as immediate expenses, but their expected benefits — besides being uncertain — are likely to be realized in the long term beyond the current fiscal period. CAPEX does not enter the income statement immediately as an expense, but depreciation expenses and other attendant costs or start-up charges such as labor, leasing, financing, and advertising expenses need to be incurred, along with investments in fixed assets. These costs enter the income statement directly and reduce managers' ability to meet earnings targets (Graham et al. 2005; Michenaud 2008; Asker et al. 2015; Ladika and Sautner 2014; Kraft et al. 2016).

Critics allege that because managers may face adverse career consequences if earnings targets set through guidance are missed, they may engage in myopic underinvestment to meet guided earnings targets. A survey by Graham et al. (2005) suggests that managers are reluctant to miss guided earnings targets because "analysts might think that the firm is out of control, to the extent that management is unable to deliver an earnings number that they had guided to in 
the first place. The consequences would be less severe for missing an unguided number."

Interestingly, criticisms against guidance mostly focus on quarterly guidance, with the implicit assumption that annual guidance may be less subject to concerns about managerial myopia (Houston, Lev, and Tucker 2010). Some managers apparently agree that annual guidance helps firms focus on longer-term goals. For instance, consider the justification that the CFO of American Water, a New Jersey-based company, gives for issuing annual guidance instead of quarterly guidance: "We do not believe in managing our business for the short-term. What is important is how the market reacts to misses on quarterly guidance. Often that shortterm reaction forces some companies to take short-term actions that don't always lead to longterm sustainable value. We are a long-term investment."3

However, the results in prior studies linking quarterly guidance and myopia are mixed. For instance, Houston et al. (2010) find no evidence that firms that stop quarterly guidance focus more on long-term investments. Call et al. (2014) find evidence that quarterly earnings guidance mitigates myopic earnings management. Chen, Huang, and Lao (2015) observe that management guidance alleviates managerial myopia. ${ }^{4}$

Because annual guidance has a longer horizon, one could argue that it may provide greater incentives for myopic underinvestment. A longer horizon implies a greater likelihood of unanticipated shocks that could limit managers' ability to meet earnings guidance. Prior

\footnotetext{
${ }^{3}$ See Russ Banham, “Letting Go of Guidance”, CFO Magazine, November 15, 2012.

${ }^{4}$ In a related unpublished working paper, Cheng, Subramanyam, and Zhang (2007) find that frequently guiding firms invest less in R\&D than occasional guiders. Their evidence, however, relates to frequent vs. occasional guiders rather than guidance practice per se. Lao (2013) and Kim, Su, and Zhu (2017) observe that quarterly guidance could increase investor short-termism. The concept of investor short-termism, however, is different from managerial myopia (Call et al. 2015).
} 
literature also finds that managers use quarterly earnings guidance to manage market expectations down (Cotter, Tuna, and Wysocki 2006; Kim and Seok 2012), whereas managers are less willing to manage expectations down with annual earnings guidance (Bergman and Roychowdhury 2008; Gong, Li, and Wang 2011; Tang, Yao, and Zarowin 2015). These characteristics of annual guidance suggest that annual guidance could be a more powerful setting to examine the link between earnings guidance and myopic underinvestment.

\subsection{Why Issue Guidance?}

An important question is if earnings guidance induces managerial myopia, why do we observe earnings guidance in practice? Prior literature associates earnings guidance with a host of beneficial consequences. These benefits include improved transparency; enhanced liquidity; decreased analyst forecast dispersion as well as earnings uncertainty; reduction in litigation risk and settlement amount; and decreased cost of equity and market-wide uncertainty (Skinner 1997; Coller and Yohn 1997; Billings and Cedergren 2015; Billings, Jennings, and Lev 2015; Balakrishnan et al. 2014; Baginski and Rakow 2012; Clement, Frankel, and Miller 2003; Shroff et al. 2013). Because of these varying benefits, it may be difficult for investors and other stakeholders to discern managerial objectives of issuing earnings guidance. Fischer and Verrecchia (2000) suggest that when there is sufficient uncertainty about managers' objectives, managers may be better off by engaging in short-term oriented actions.

Further, adverse selection arguments imply that the cost of not issuing value-relevant information such as earnings guidance may occur immediately. For example, Chen, Matsumoto, and Rajgopal (2011) find that when firms stop issuing guidance, stock prices react 
negatively, consistent with the notion that investors assume managers must be hiding bad news when they stop issuing guidance. In contrast, the cost of short-termism may manifest only in the long run. That is investors do not observe investment opportunity sets available to managers (due to information asymmetry between managers and outsiders), so that they may be unable to estimate the optimal level of investments when they observe actual investment levels. This uncertainty with optimal investment levels may resolve gradually. Prior empirical studies (e.g., Bhojraj et al. 2009; Kothari, Mizik, and Roychowdhury 2016) find evidence consistent with this intuition. This line of reasoning suggests that for some managers, the immediate cost of adverse selection of not issuing guidance may outweigh the long-term cost of short-term oriented actions. Chapter 11 further elaborates on this issue. 


\section{Chapter 3}

\section{Identification}

\subsection{Endogeneity of Earnings Guidance}

A key challenge in estimating the effect of management forecasts on firm investment is that guidance is a choice variable and therefore endogenous. There are several potential sources of endogeneity in this relation.

To illustrate, think of an R\&D-intensive firms, which often suffer from significant information asymmetry. As a result, demand for information is high, which may encourage managers to release value-relevant information such as earnings guidance. This would mean that one would obtain a spurious positive association between earnings guidance and R\&D investments when one employs the OLS regression without correcting for endogeneity. Further, there are likely to be substantial number of omitted factors in a given specification, particularly because we cannot exhaust including all variables that mediate the relation between earnings guidance and firm investments.

Finally, there are significant measurement errors in the proxies for management forecasts. Chuk, Matsumoto, and Miller (2013) compare a sample of hand-collected management forecasts from company press releases with the CIG database and find that $41 \%$ of firm-years forecasting in press releases are not covered by the CIG database. Chuk et al. (2013) also suggest that the errors in CIG coverage are systematic and vary predictably with 
analyst coverage, institutional ownership, and firm performance. These systematic factors are also likely to be correlated with managerial incentives to act myopically, implying that relying on OLS estimates without having an instrument poses a threat to the validity of the inferences (Wooldridge 2002).

\subsection{Institutional Background}

To tackle this identification challenge, I exploit a natural experiment and employ an instrumental variable (IV) estimation approach. The natural experiment I use in this thesis comes from the staggered adoption of Inevitable Disclosure Doctrine (IDD) by several states. ${ }^{5}$ If an employee of a firm located in an IDD-adopting state knows trade secrets that are likely to impose costs on the employer in the form of increased competitive threats when revealed to a competitor, the employer could ask the court to bar that employee from working for a competitor. In such cases, the court usually bars the employee from working for the competitor for a period and/or allows the employee to work but only to undertake a limited set of responsibilities so that trade-secret disclosure is less likely. The injunction would also apply to employees who start their own businesses where they could potentially use trade secrets they gathered while working for former employers.

Several features of IDD are worth noting. First, the protection afforded by IDD encompasses both intentional and inadvertent disclosure of trade secrets by employees. Second, the protection afforded by IDD extends beyond the state's boundaries, even to states

\footnotetext{
${ }^{5}$ The institutional background in this section relies on Klasa et al. (2017).
} 
that do not enforce IDD. Third, IDD strengthens the enforcement of non-compete agreements (NCA), which are often included in employment agreements. But even when NCA are not included, IDD could apply if the departing employee possesses trade secrets. As a result, IDD has a wider scope than NCA. ${ }^{6}$ Fourth, the U.S. Department of the Treasury (2016) reports that $24 \%$ of private-sector employees acknowledge that they possess trade secrets, implying that IDD affects a significant proportion of firm employees. More importantly, IDD affects key employees including - but not limited to-managers (top-, mid-, or even lower-level managers), knowledge workers (e.g., scientists and engineers), and other employees who have accumulated significant human capital and whose retention is key to the continued success of the firm. Finally, former or current employees are considered the biggest threat to the protection of trade secrets (Forester Consulting 2010; Almeling 2012). As such, IDD protects firms from the most potent source of trade-secret divulgence.

\subsection{How IDD Affects Management Forecasts}

Disclosure theories rest on the central premise that adverse selection costs provide a strong incentive for managers to release value-relevant information, such as earnings guidance. However, the difficulty in predicting earnings into the future as well as the proprietary cost of disclosure could prevent managers from issuing earnings guidance. I argue below that IDD relaxes these constraints such that managers may be incentivized to issue earnings guidance.

\footnotetext{
${ }^{6}$ NCA are not often not enforceable beyond a certain radius such as the city limit or state.
} 


\subsubsection{Uncertainty Mechanism}

Reduced risk of trade-secret divulgence makes earnings less contingent on rivals' strategic actions, thereby leading to reduced earnings uncertainty. Indeed, top managers rate firms' trade secrets as the most important form of revenue-generating intellectual property (Cohen, Nelson, and Walsh 2000; Klasa et al. 2017). Further, retention of key employees is a direct and important contributor to firm profitability. To the extent that uncertainty surrounding factor inputs (i.e., key employees) translates into uncertainty about productivity and earnings, the adoption of IDD reduces earnings uncertainty.

To illustrate, consider a firm that utilizes a Cobb-Douglas production technology, $Y=$ $A L^{\alpha} K^{\beta}$, where $Y$ is the total output, $A$ is the total factor productivity (e.g., knowledge capital), $L$ is the labor input, $K$ capital input and $\alpha, \beta$ are respective output elasticities to labor and capital factors. $^{7}$ The state adoption of IDD reduces uncertainty about $A$ because it enables stronger protection of trade secrets, about $L$ by enhancing greater retention of key employees. Because productivity of $K$ also depends on $A$ and $L$, IDD is also likely to reduce uncertainty about $K$. As such, IDD reduces uncertainty about $Y$, and hence earnings.

Prior literature argues that uncertainty is an important factor that dissuades firms from providing more forecasts (Waymire 1985; S. Chen, Matsumoto, and Rajgopal 2011; Bozanic, Roulstone, and Van Buskirk 2018; Lin, Wei, and Wu 2016). CFOs frequently mention uncertainty as a key impediment to providing earnings forecasts (Chen et al. 2011). Uncertainty makes it more likely that realized earnings will not match forecasted earnings, thus exposing

\footnotetext{
${ }^{7}$ I use Cobb-Douglas production function to provide intuition but the arguments hold for an arbitrary production function.
} 
managers to reputational and litigation risk. Relying on these arguments and evidence in prior literature, I argue that the state adoption of IDD may encourage firms to provide earnings forecasts.

\subsubsection{Employee Rent Extraction Mechanism}

Kleiner and Bouillon (1988) find that revealing information about a firm's financial condition, productivity, and future investments leads to higher wage levels. As such, firms may strategically disclose less to reduce the likelihood of rent extraction by employees. Hilary (2006) cites Reynolds, Masters, and Moser (1998) and comments "an important feature of the [labor] negotiations is an effort to conceal or even misrepresent one's true position."

Bova et al. (2015) show both theoretically and empirically that firms provide fewer management forecasts when employee bargaining power is high. The intuition is that keeping employees in the dark may weaken their negotiation leverage. Key employees' negotiation leverage stems mainly from the transferability and attractiveness of accumulated human capital to rival organizations. Because the adoption of IDD significantly reduces key employees' outside options, their bargaining power (or reservation utility) vis-à-vis the firm declines. Following the above discussion, IDD may encourage firms to provide more earnings forecasts. ${ }^{8}$

\footnotetext{
${ }^{8}$ Employee rent extraction mechanism applies less to top executives who are likely to have information about projected performance with or without earnings guidance.
} 


\subsubsection{Annual vs. Quarterly}

Because annual forecasts have a longer time lag prior to earnings realization, earnings unpredictability is more salient for annual forecasts than quarterly forecasts. Further, proprietary costs arising from employee bargaining power are likely to be higher for annual forecasts because annual guidance allows employees a significant amount of time to process the information and react strategically. Prior literature also suggests that proprietary costs are higher for annual guidance (Li 2010; Ali, Klasa, and Yeung 2014). Verrecchia (1983) remarks, "the proprietary cost is a continuous, decreasing function of time which approaches zero after some interval has elapsed." These arguments suggest that IDD is more likely to affect forecasts about annual earnings than those about quarterly earnings.

\subsubsection{Other Mechanisms}

IDD could affect earnings guidance through other mechanisms, too. Li, Lin, and Zhang (2017) observe that firms are more likely to redact customer information from 10-K filings following the adoption of IDD. Their study suggests that IDD increases the marginal proprietary cost of disclosing customer information because competitors can no longer gain access to such information by poaching key employees. If competitors rely more on earnings guidance for proprietary information following the adoption of IDD, one could argue that IDD will increase the proprietary cost of issuing earnings guidance (Aobdia 2018). It is also possible that IDD increases the proprietary cost of disclosing customer information that results from competitors' strategic reactions but decreases the proprietary cost of earnings guidance that results from key employees' strategic reactions. 


\section{Chapter 4}

\section{Data, Variables, and Research Design}

\subsection{Sample Selection}

I begin the sample selection procedure by retrieving financial-statement data items for all nonfinancial firms from Compustat. I drop firms located outside the U.S. or missing state information. Analyst coverage data come from Institutional Brokers' Investment System (I/B/E/S), institutional ownership data from Thomson Reuters (Form 13F), and management forecasts data from First Call's Company Issued Guidance (CIG). Following Anilowski, Feng, and Skinner (2007), the sample period begins in 1994. Thomson Reuters ends CIG coverage in 2011 and as a result, my sample period ends in 2011. After requiring the availability of data for all control variables, I arrive at 95,427 firm-year observations. All continuous variables, except for Age, are winsorized at $1 \%$ and $99 \%$ of their respective empirical distributions to mitigate the influence of outliers.

\subsection{Variable Construction}

Following Houston et al. (2010), I proxy managerial myopia by investments in R\&D and CAPEX. In addition, based on the evidence in Graham, Harvey, and Rajgopal (2005), I also consider SGA expenses. These outcome variables are scaled by book assets. 
The key test variable of interest is the number or incidence of numerical annual forecasts in a fiscal year. I set the guidance variable to zero if no record of guidance is found in the CIG database for a firm-year. The state adoption of Inevitable Disclosure Doctrine is captured by the variable IDD that equals one for all fiscal years greater than or equal to the adoption year for firms located in adopting states and zero otherwise. IDD reverts to zero if a state rejects the doctrine after having previously adopted it. I take the headquarter state of a firm to be its business location. Since Compustat backfills the firm headquarter address with the most recent available address, I retrieve historical business location addresses from the U.S. Securities and Exchange Commission (SEC)'s EDGAR database. For precedent-setting court decisions on IDD, I rely on prior studies (e.g., Klasa et al. 2017; D. Chen, Gao, and Ma 2016; Y. Li, Lin, and Zhang 2017), that collected IDD precedent-setting cases from legal experts and studies published in law journals. To ensure the accuracy of the precedents, I judiciously read and validate the transcripts of court verdicts listed in these studies that fall within the sample period between 1994 and 2011. ${ }^{9}$ Appendix A lists all precedent-setting state adoption (rejection) of IDD within the sample period.

I also include time-varying covariates that could potentially influence a firm's decision to issue management forecasts or affect firm outcomes, such as managerial myopia or the

\footnotetext{
${ }^{9}$ I find that all the cases they list set precedents for lower courts in the hierarchy except for Del Monte Fresh Produce Co. v. Dole Food Co., Inc., 148 F. Supp. 2d 1326 (S.D. Fla. 2001). Klasa et al. (2017) interpret the Florida court's rejection of IDD in 2001 as a regime change of an earlier precedent set in 1964. However, the transcript of verdict in Florida (2011) decision suggests that Florida had neither adopted nor ever discussed the issue of IDD before 2001. In particular, the judge explains, "Florida has not had an opportunity to discuss inevitable disclosure" (S.D. Fla. 2001, p. 1337). In line with the verdict transcript, I do not include Florida (2011) as a reversal of previously set precedent in Florida. Inferences, however, remain unaffected if I consider Florida (2011) as a precedent-altering court decision.
} 
information environment. These controls include size, age, leverage, institutional ownership (InstOwn), analyst coverage (\#Analyst), earnings volatility (EarnVol), industry concentration (HHI), net equity issuer indicator (Equity), and loss firm indicator (Loss). Following Giroud and Mueller (2010), I use Size-squared to account for possible nonlinear effects of firm scale on firm performance and/or management forecasts. I also include HHI-squared, since industry competition may have nonlinear effects on disclosure and growth opportunities (Aghion et al. 2005; Lang and Sul 2014). All variables are defined in Appendix B.

\subsection{Model Specification}

Management guidance tends to be highly sticky, suggesting that some time-invariant firmspecific unobservable factor (or combination of factors) drives a firm's decision to provide forecasts. I employ firm fixed-effect specifications to control for biases arising from such unobservable time-invariant heterogeneities. To control for secular time-trends and macroshocks that affect all firms in the sample, I include year fixed effects in all my regressions. The main specifications I estimate are:

$$
\begin{aligned}
& \text { Annual_Guidance }_{\mathrm{it}}=\delta_{1} \mathrm{IDD}_{\mathrm{it}}+\mathrm{X}_{\mathrm{it}} \delta_{2}+\gamma_{\mathrm{i}}+\mu_{\mathrm{t}}+\omega_{\mathrm{it}} \\
& \mathrm{y}_{\mathrm{it}}=\beta_{1} \text { Annual_Guidance }_{\mathrm{it}}+\mathrm{X}_{\mathrm{it}} \beta_{2}+\gamma_{\mathrm{i}}+\mu_{\mathrm{t}}+\varepsilon_{\mathrm{it}}
\end{aligned}
$$

In Eqs. (1) and (2), i indexes firm, $t$ indexes fiscal year, and $y$ stands for one of the outcome variables depending on the specification. $\mathrm{X}$ is the matrix of all time-varying control variables, and $\beta_{2}$ and $\delta_{2}$ are column vectors of coefficients associated with these control variables. All specifications also include firm fixed effects $\left(\gamma_{i}\right)$ and year fixed effects $\left(\mu_{t}\right)$. Finally, $\varepsilon_{i t} \sim N\left(0, \sum_{g}\right)$ and $\omega_{i t} \sim N\left(0, \sum_{h}\right)$ are the error terms allowing for within group (g/h) arbitrary correlations. I cluster standard errors at the firm level to mitigate the overstatement 
of statistical significance owing to serial correlation in the error term. Recent evidence in Mackinnon and Webb (2017) suggests that when clusters are unbalanced, one may require substantially more clusters than the number of states in the US to obtain consistent clusterrobust standard errors. As a result, clustering at the state level may not be advisable. Nonetheless, in robustness tests, I also use headquarter state, state-year, and two-way firm plus state-year clustering. The test variable is Annual_Guidance $\in$ \{Number of Annual Guidance, Incidence of Annual Guidance $\}$ and $\beta_{1}$ is the key coefficient of interest. Endogeneity refers to the problem that the OLS assumption of no correlation between the error term $\left(\varepsilon_{\mathrm{it}}\right)$ and Annual_Guidance does not hold in Eq. (2) because of omitted variable bias, reverse causality, or measurement error.

To overcome this endogeneity problem, I estimate instrumental variable specifications. Intuitively, I partition Annual_Guidance into two components: one component is correlated with the error term and the other is orthogonal to the error term in Eq. (2). Since endogeneity comes from the component that is correlated with the error term, I use only part of the variation in Annual_Guidance (that is uncorrelated with the error term). To achieve this objective, I use IDD as an instrument that correlates strongly with Annual_Guidance but is otherwise likely to be uncorrelated with the error term $\left(\epsilon_{\mathrm{it}}\right)$. I regress Annual_Guidance on IDD and other controls and use the fitted values from the Eq. (1) in place of Annual_Guidance in Eq. (2) for the second-stage regression. To the extent that IDD satisfies the relevance and exclusion conditions, fitted values from Eq. (1) will be uncorrelated with the error term $\left(\epsilon_{\mathrm{it}}\right)$ in Eq. (2), leading to a consistent estimate of $\beta_{1}$. 


\section{Chapter 5}

\section{Results and Analyses}

\subsection{Descriptive Statistics}

Table 1-A reports summary statistics for some of the key variables used in the main analyses. Table 1-B shows the correlation matrix of key variables. During the sample period, firms on average spend 33\% of assets in SGA, 6.5\% in R\&D, and 5.7\% in CAPEX. An average firm has market-to-book ratio of 2.24, $\$ 1.6$ billion in assets, and is 17 years old. Further, firms have on average 0.23 debt-to-assets ratio, $25 \%$ shares owned by institutions, and are covered by four analysts. Firms provide 0.39 (0.35) annual (quarterly) numerical forecasts on average and $12 \%$ $(13 \%)$ of firms issue at least one annual (quarterly) guidance in a fiscal year.

\subsection{Analyses of the First Stage: State Adoption of IDD and Management Forecasts}

I begin the analyses by examining the strength of first-stage results of 2SLS regressions. Table

2 presents the estimates for the effect of the adoption of IDD on management forecasts. All 
specifications are estimated using the OLS regressions. ${ }^{10}$ Columns (1) regresses the number of annual management forecasts that a firm provides in a given fiscal year on IDD and other control variables, including firm and year fixed effects. Treatment firms increase the frequency and likelihood of annual earnings guidance relative to control firms. The increase in annual forecasts is statistically significant at the $1 \%$ level. An average firm provides nearly $36 \%$ $(=0.14 / 0.39)$ more annual numerical forecasts following the adoption of IDD. In Column (2), I regress the incidence of annual forecasts on IDD and other controls. The positive coefficient estimate suggests that the likelihood of issuing numerical annual forecasts increases by nearly 23\%. Columns (3)-(4) conduct the same analyses for quarterly earnings guidance. I do not observe any statistically discernible changes in quarterly earnings guidance following the state adoption of IDD.

Returning to the control variables in Columns (1)-(2), Size has a nonlinear effect on firms' incentives to provide annual forecasts. Older firms generally provide fewer annual forecasts - possibly because investors already have information from other sources about older firms - up to a certain point, beyond which size positively associates with annual forecasts. This could be because very large firms have complex operations, and investors require more information about such firms. Corporate debt (leverage) is negatively associated with forecasts, potentially because debt-holders have access to superior information, preempting the need for management forecasts. Institutional ownership and analyst coverage both are positively

\footnotetext{
${ }^{10}$ Note that I use the OLS regression in Table 2 despite the dependent variables being either count or binary. This is because Table 2 is the first stage of a two-stage least squares (2SLS) estimation (see Table 4 for the $2^{\text {nd }}$ stage), which requires the first stage to be linear for consistent 2SLS estimates (Angrist and Krueger 2001).
} 
associated with management forecast frequency. Loss firms provide fewer numerical annual forecasts. Consistent with higher litigation exposure when issuing equity, firms that issue equity provide fewer annual forecasts. Uncertainty about performance (EarnVol) also reduces the frequency of annual forecasts. Finally, consistent with the conjecture of Lang and Sul (2014), industry concentration has a nonlinear effect on firms' incentives to issue annual forecasts, though it is generally not statistically significant. Controls for quarterly forecasts in Columns (1)-(2) have similar signs and magnitudes, except for Size and Age.

One concern is that the increase in annual guidance could come at the expense of less precise and timely forecasts. I construct two variables to mitigate this concern. logPrecision is the logarithm of (one plus) the average precision of all earnings guidance in a fiscal year. Precision for a forecast equals 3 if it is a point forecast, 2 if it is range forecast, 1 if it is a minimum or maximum, and zero otherwise. logTimeliness is the logarithm of (one plus) the average timeliness of all forecasts. Timeliness for a forecast is the number of days between the forecast and the end of reporting period. Table 3 shows the results. I find that IDD increases the precision and timeliness of annual numerical forecasts. The coefficient estimates for annual precision and timeliness in Columns (1)-(2) are significant at the $1 \%$ levels. In terms of economic significance, treatment firms increase the precision of the annual forecasts by $5.2 \%$ and timeliness by $11.3 \%$. Columns (3)-(4) show that IDD does not affect the precision and timeliness of quarterly forecasts

\subsection{Main Results: Annual Earnings Guidance and Myopic Underinvestment}

In this section, I discuss the key results of the thesis. Table 4, Panel A, reports the results from 
both instrumental variable (IV) and OLS regressions of each of SGA, R\&D, and CAPEX (scaled by assets) on the number of annual management forecasts and other controls. Columns (1)-(3) report the 2SLS estimates, where I use IDD as an instrument for annual guidance frequency. Across all three proxies, I find consistent evidence that annual guidance leads to myopic underinvestment in SGA, R\&D, and CAPEX. The estimates are statistically significant at the 5\% level. For an average forecasting firm (that provides 0.39 annual forecasts), the adverse treatment effect is equivalent to a decrease in SGA by 3.8\% (sample average 33\%), R\&D by $1.25 \%$ (sample average $6.5 \%$ ), and CAPEX by $0.94 \%$ (sample average $5.7 \%$ ) of book assets. Relative to the sample averages, the economic magnitudes of the adverse treatment effects are meaningful.

Columns (4)-(6) tabulate the OLS estimates. Column (4) shows that SGA is negatively associated with annual management forecasts. The coefficient is statistically significant at the $1 \%$ level. This result is consistent with the hypothesis that annual guidance fosters myopic underinvestment in SGA. Column (5) shows a statistically significant (at 10\%) positive association between $R \& D$ investment and annual forecasts. Column (6) also shows a positive association between CAPEX and annual forecasts. The coefficient is statistically significant at the $1 \%$ level and suggestive of annual guidance mitigating myopic underinvestment in CAPEX. Overall, the results of OLS estimates do not point to a coherent conclusion as to whether annual guidance fosters or mitigates managerial myopia. The coefficient magnitudes are very close to zero.

I examine how annual guidance incidence affects managerial myopia in Table 4, Panel B. Columns (1)-(3) provide 2SLS estimates. As in Panel A, I use IDD as the instrument for annual forecast incidence. Consistent with the evidence from 2SLS estimates in Panel A, I 
observe that the practice of providing annual guidance leads to large declines in SGA, R\&D, and CAPEX. The treatment effects are statistically significant at the $5 \%$ level. Given that the unconditional annual forecast likelihood in the sample is 0.12 , the adverse effects of annual forecast on SGA is $5.76 \%$, on R\&D is $1.91 \%$, and on CAPEX is $1.43 \%$. Compared to the sample averages (SGA 33\%, R\&D 6.5\%, and CAPEX 5.7\%), these magnitudes are economically substantial.

In Table 4, Panels A and B, I also provide Angrist-Pischke F-statistics for a weak instrument test. In Panel A, where I use the frequency of annual guidance as the key independent variable of interest, the F-statistic is 15.72, and in Panel B, where I use annual forecast incidence as the key independent variable, the F-statistic is 14.44. Given that the critical value for the first-stage F-test of weak instruments is 10, the F-statistics in both panels reject the null hypothesis that the instrument is weak. That IDD is a strong instrument for annual guidance is reassuring because a weak instrument could amplify the adverse effects of even a mild violation of the exclusion restriction.

In Table 4, Panel C, I report reduced form estimates where I regress the myopia proxies on the instrument (IDD) itself and all controls using the OLS regression as is suggested in the IV literature (Angrist and Krueger 2001; Angrist and Pischke 2009; Atanasov and Black 2017). In my setting, this constitutes a $\mathrm{DiD}$ approach with firm fixed effects where IDD proxies for an increase in annual management guidance. As expected, the estimates suggest that IDD leads to significant declines in SGA, R\&D, and CAPEX. The treatment effect for each measure is statistically significant at the $1 \%$ level.

In robustness tests, I check the robustness of the results to different clustering choices. Specifically, I cluster by the state of location and state-year. I further use two-way clustering 
along firm and state $\times$ year dimensions. Inferences continue to hold (Table 5 Panels A, B, and C). Overall, the evidence in this chapter suggests that managers engage in myopic underinvestment to meet earnings targets set through annual earnings guidance. 


\section{Chapter 6}

\section{Consequences of Managerial Myopia}

Underinvestment is likely to be followed both by adverse real consequences and capital market consequences. In this chapter, I examine how myopic underinvestment owing to earnings guidance affects revenue growth, innovation, and market assessment of growth opportunities.

In Table 6, Panel A, I find that an increase in guidance (as proxied by IDD) leads to a statistically significant decline in revenue growth two years into the future. Interestingly, contemporaneous and one-year ahead effects are not statistically significant but one notices a gradual declining trend in the coefficient estimates as one progresses into the future.

Prior literature uses patents and citations as measures of R\&D investment efficiency. If the decline in $R \& D$ is an indication of myopia, then I expect to see a gradual decline in innovation outputs as proxied by patents. I gather patent data from Kogan et al. (2016). $\log$ Patent is the natural logarithm of (one plus) the total number of patents applied for and eventually granted by United States Patent and Trademark Office (USPTO) in a fiscal year. ${ }^{11}$ Panel B reports the results from the regression of patents on IDD and the controls. The results

\footnotetext{
${ }^{11}$ The dataset by Kogan et al. (2016) captures data up until 2010. For these tests, I curtail the sample period in 2006 because some patents applied in the later years of the sample may not have been granted as yet.
} 
suggest that firms experience a gradual decline in innovation after an increase in annual guidance as proxied by IDD. I find similar results using citations as a measure of innovation in Panel C.

In Table 6, Panel D, I observe a gradual decline in raw stock returns following the state adoption of IDD. The economic magnitude of the decline in the first year is moderate $(1.7 \%)$ and but not statistically significant. However, the effect becomes larger both in terms of economic magnitude and statistical significance in the second year (5\%) and third year (3.4\%). The effect is statistically insignificant in the fourth year (untabulated). This gradual reaction is consistent with investor uncertainty about expected cash flows from investments resolving gradually or investors failing to fully appreciate the effect of underinvestment on firms' future cash flows.

The analyses in this chapter also rule out the hypothesis that a reduction in investment could potentially be a reduction in overinvestment. If guidance improves transparency, then better monitoring would help curb overinvestment, resulting in investment efficiency. However, the investment efficiency hypothesis cannot explain the decrease in revenue growth, innovation, and market assessment of growth opportunities that accompany cuts in investments. 


\section{Chapter 7}

\section{Evidence on the Exclusion Restriction}

A key concern with the IV estimates is whether IDD exacerbates myopic underinvestment through some mechanism other than annual guidance (that is, the exclusion restriction is violated). In this chapter, I provide evidence that the exclusion restriction is likely to be satisfied.

\subsection{Cross-Sectional Analyses}

If the observed myopic underinvestment in Table 4 is due to a corresponding increase in annual guidance, then one would also expect the cross-sectional variations in myopic underinvestment to closely follow cross-sectional variations in annual guidance. I conduct several crosssectional analyses in this section to corroborate this prediction.

The effect of IDD on annual guidance is likely to be more salient for firms that rely on trade secrets for sustainable competitive advantages. I construct an indicator variable, Trade Secret Intensity, for firms in industries that rely on trade secrets. The 2011 Business Research and Development and Innovation Survey (BRDIS) conducted by the U.S. Census Bureau identifies firms in computers, electronics, petroleum, chemical, drugs, and scientific R\&D services industries as those that consider trade secrets to be very important for their firms' 
continued success. I use Fama-French 48 classifications to identify these industries. ${ }^{12}$

Because IDD reduces earnings uncertainty, I expect the effect of IDD on guidance to be more pronounced for firms with greater uncertainty. I proxy uncertainty about firm fundamentals with industry earnings volatility (Earnings Uncertainty). The greater the number of close rivals to which employees could move, the more credible is the employee rent extraction threat. I construct an indicator variable, Close Rivals, that equals one if the competition from close rivals is greater than the industry-year median, zero otherwise. ${ }^{13}$ Adverse selection costs of not issuing earnings guidance is likely to be higher for managers if investor demand for earnings news is greater and if investors are unsure about managers' ability, such as when the CEO is new. ${ }^{14}$ I measure investor demand for earnings news by stock price sensitivity to earnings (earnings response coefficient, or ERC). Following Asker et al. (2015), I calculate ERC at the Fama-French 48 industry level each year.

Table 7, Panel A reports the results of how IDD affects annual guidance conditional on these cross-sectional incentives. I test the cross-sectional variations in the effects of IDD on annual guidance by including interaction variables in Columns (1)-(5). Column (1) shows that

\footnotetext{
12 The survey is available at: https://www.nsf.gov/statistics/2015/nsf15307/pdf/nsf15307.pdf

13 Hoberg and Phillips (2016) use 10-K business descriptions to construct time-varying firm-year measure of market structure. The measure captures product market competition arising from firms competing in similar product space.

${ }^{14}$ Forecasting is an important skill for choosing among competing projects based on expected cash flows. Further, guidance implies that managers have received value-relevant, timely, and precise information about expected cash flows. As such, guidance is an observable signal of managerial ability (Trueman 1986; Baik, Farber, and Lee 2011; Lee, Matsunaga, and Park 2012). Newly hired CEOs have greater incentives to signal their ability because investors are uncertain about CEO ability in the early years of tenure (Gibbons and Murphy 1992; Ali and Zhang 2015).
} 
the state adoption of IDD has a significantly more pronounced effect on earnings guidance for firms with valuable trade secrets. Column (2) reports that IDD has a more pronounced effect for firms which have the threat of employee rent extraction. Columns (3)-(5) show that the effect of IDD on annual guidance is more salient when firms have more uncertain earnings, when ERC is greater, and when CEO tenure is shorter, respectively.

Next, I examine whether myopic underinvestment also predictably follows the crosssectional variations in the effect of IDD on annual guidance. Table 7, Panel B suggests that myopic underinvestment is more pronounced when firms have more trade secrets, employee rent extraction threat is more credible, earnings are more uncertainty, price-earnings sensitivity is greater, and CEO tenure is shorter. The fact that the cross-sectional variations in myopic underinvestment closely follow the cross-sectional variations in annual guidance is comforting because it limits the set of plausible alternative interpretations.

\subsection{Rejection of IDD}

Appendix A shows that two states, Michigan and Texas, rejected IDD after having previously adopted it. If adoption of IDD leads to an increase in earnings guidance release, then rejection of IDD should reduce earnings guidance. Further, if earnings guidance is the mechanism through which IDD induces managerial myopia, one would expect symmetric but opposite effects of rejection of IDD on managerial myopia. In Table 8, I examine this prediction. I include firm-year observations of five years prior to the Michigan shock and five years subsequent to the Texas shock to execute this test. I find that firms provide fewer annual forecasts and invest more in R\&D and CAPEX when states reject IDD. 


\subsection{Falsification Analyses}

The above discussion and tests rule out potential alternative interpretations of the findings in the thesis and corroborate the contention that IDD as an instrument satisfies the exclusion restriction. In this section, I conduct two falsification tests to provide further evidence that the instrument satisfies the exclusion restriction.

\subsubsection{Falsification Test 1}

To execute the first falsification test, I take advantage of the staggered state adoption of IDD by four states in the1980s, when management forecasts were rare due to litigation concerns. ${ }^{15}$

Furthermore, precise management forecasts in the form of point or range estimates were even scarcer (Skinner 1995). Referring to the rarity of management forecasts in this period, the SEC (1994, p. 16) observe, "Recent surveys suggest that this threat of shareholder litigation, whether real or perceived, has had a chilling effect on disclosure of forward-looking information."

I argue that in the absence of management forecasts, IDD is likely to positively affect firm investment for several reasons. For example, investments in human and organization

\footnotetext{
${ }^{15}$ To motivate managers to provide more forward-looking statements, Congress subsequently enacted the Private Securities Litigation Reform Act (1995) that shielded managers from being sued for issuing forward-looking statements. In response, firms increased issuing management forecasts significantly. The Securities Litigation Uniform Standards Act (1998) made it even more difficult to bring lawsuits against managers for issuing forwardlooking statements that later prove inaccurate. Finally, Regulation Fair Disclosure (2000) further encouraged managers to publicize forecasts widely to the public rather than to select analysts.
} 
capital (SGA) are more lucrative when competitors cannot poach key employees. Similarly, investments in $\mathrm{R} \& \mathrm{D}$ are contingent upon trade-secret protection and retention of scientists and engineers (Hall and Lerner 2010). Appropriation of rents from capital expenditures (CAPEX) is more feasible when firms have better protection against trade-secret theft, and when key employees who accumulate important human and organization capital can be retained for a longer term. In short, returns to investments are often contingent on the continued retention of key employees and protection of trade secrets (Autor, Kerr, and Kugler 2007; Jeffers 2016).

To operationalize these tests, I hand-collect management forecast data for a sample of firms in the falsification sample period. To reduce the costs of manual collection, I use a contiguous states sample framework. That is, for firms located in each of the four states that adopted IDD in the 1980s, I use firms located in the contiguous state as controls. ${ }^{16}$ I drop firms with book value less than 500 million USD since larger firms are more likely to provide forecasts. This process generates a sample of 371 firms (2,682 firm-year observations). For this sample, I gather management forecast data by searching Factiva. ${ }^{17}$ Table 9, Panel A shows that IDD does not affect management forecasts either statistically or economically. ${ }^{18}$ That is, litigation concerns seem to outweigh any other perceived benefits associated with IDD in

\footnotetext{
${ }^{16}$ For firms located in PA and NJ, I use firms located in NY as the control sample. For IL and MN, I use IA and WI firms respectively.

17 I search Factiva for all management forecasts issued between 1980 and 1990 for each pre-screened firm separately using keywords such as earn, earnings, profit, performance, improvement, gain, loss, revenue, EPS, income, growth. I download all the articles thus generated and carefully read for management forecast news. I arrive at 692 forecasts, with 487 (70\%) annual and 205 (30\%) quarterly forecasts. Out of the 487 annual (205 quarterly) forecasts, $28 \%$ (17\%) are point or range forecasts, and the rest are maximum/minimum forecasts.

${ }^{18}$ A drawback of the falsification tests in Table 9 and 10 is that the sample size is small in comparison to the main sample in Table 4.
} 
shaping firms' management forecast decisions in this period. Panel B provides the results for the effect of IDD on firm investments, showing that IDD has a positive impact on investments in the absence of management forecasts. These falsification tests provide credibility to the results in the main sample that, had it not been for management forecasts, IDD would have encouraged more investments.

\subsubsection{Falsification Test 2}

A concern with the above falsification test is that the sample period (1980-1990) is different from the main sample period (1994-2011). As a result, some omitted factors could potentially be different for the two sample periods. For example, local economic shocks and industry factors that are different in the two sample periods may drive the results. To further mitigate this concern, I examine how investments of firms with public debt but no public equity and large private firms that are subject to the same SEC filing requirements as the treatment firms react to the state adoption of IDD. These firms do not issue earnings guidance but experience the same local and industrial economic conditions as the treatment firms in the main sample. As such, if omitted factors other than equity market pressures induced by earnings targets are the primary drivers of the results, then one would observe similar negative impact of IDD on investments for these firms too.

The sample firms for this falsification test include (i) firms that have public debt but do not have public equity (ii) large private firms with more than $\$ 10$ million in assets whose securities are held by at least 500 owners. Both types of firms are required by SEC to file the same financial reports as the publicly listed firms. As a result, financial data for these firms are 
available from Compustat. To arrive at this sample, I retrieve firms that do not have data on market prices in the Compustat/CRSP database. Other than that, I apply the same filters as the main sample. Table 10 reports the results. I find that investment in CAPEX increases following the state adoption of IDD. Investments in R\&D and SGA do not change materially. Therefore, state-level economic shocks and industry conditions cannot explain the results I find in the main sample.

\subsection{Revising Expectations}

Managerial myopia hypothesis suggests that managers engage in myopic underinvestment to meet guided earnings targets. If, however, managers are forthcoming with revising down market expectations, then one may expect firms to have less need for myopic underinvestment. I construct an indicator variable, Revise_Down, that takes one if managers guide earnings down (zero otherwise) and interact it with IDD. I observe that myopic underinvestment is less pronounced for firms that revise guidance down subsequently (Table 11, Panel A). For firms that confirm market expectations set by previous guidance or revise up the guidance, I do not observe any such effect (Table 11, Panel B). This evidence is informative because an alternative explanation is unlikely to be consistent with this evidence. ${ }^{19}$

19 A problem with the results in Table 11 is that both Revise_Down and Confirm/Revise_Up are affected by the state adoption of IDD and are endogenous. As a result, it is difficult to draw strong conclusions from the evidence in this table. 


\subsection{Does Myopic Underinvestment Help Firms Meet or Beat Earnings Guidance?}

If the investment cuts are motivated by managers' intention to avoid missing earnings guidance, then treatment firms are more likely to meet or beat annual earnings guidance. To test this prediction, I construct an indicator variable Meet or Beat that equals one if firms meet or beat the final updated annual earnings guidance in a fiscal year, zero otherwise. ${ }^{20}$ Table 12 , Column (1) shows that treatment firms are more likely to meet or beat annual earnings guidance than the control firms. In Column (2), I construct an indicator variable Meet or Barely Beat that equals one if firms meet or beat the final updated annual earnings guidance within ten cents, zero otherwise. I find that treatment firms are more likely to meet or barely beat annual earnings guidance.

${ }^{20}$ For range forecasts, I take the midpoints as the earnings targets. Inferences are unaffected if I use lowest or highest end of the range forecasts as the earnings targets. 


\section{Chapter 8}

\section{Testing Alternative Mechanisms}

The analyses in Chapter 7 should largely mitigate concerns about the violation of exclusion restriction. To address residual concerns about the violation of exclusion restriction, in this chapter I directly test and discuss potential alternative explanations.

\subsection{Executive Compensation Structure and Risk-taking Incentives}

If IDD affects managerial compensation structure, such changes could explain the result I find in the thesis. ${ }^{21}$ To test this conjecture, I gather data on top-executive pay-performance sensitivity (delta), wealth-stock volatility sensitivity (vega), and stock- and option-portfolio value (inside equity) from Coles, Daniel, and Naveen (2006), who calculate these metrics based on Core and Guay (2002). Table 13, Panel A reports the results. I do not observe any discernible changes in (log of) delta and (log of) inside equity, but find that vega increases by

${ }^{21}$ For example, shareholders may reduce equity-based compensation for managers following the state adoption of IDD because retaining key employees becomes easier even without long-term incentive plans. 
$12.6 \%$ (t-stat=2.66) for treatment firms relative to control firms. ${ }^{22}$ As a result, changes in managerial compensation structure cannot explain the evidence of myopic underinvestment. The positive effect of IDD on vega is consistent with the notion that shareholders expect greater returns from risky investments following state adoption of IDD, suggesting an increase in the optimal investment levels from shareholders' perspectives. Note that this evidence is consistent with the inference from the falsification analyses. Because managers may not be willing to take greater risk for compensation-related incentives, shareholders incentivize them by increasing the sensitivity of managerial wealth to risk-taking (Gormley, Matsa, and Milbourn 2012).

\subsection{Barrier to Entry/Competitive Pressure}

IDD increases the entry costs for potential competitors. Since long-term investments tend to increase entry barriers, firms could view entry barriers afforded by IDD and by investments in long-term projects as substitutes. However, Frésard and Valta (2016) find that firms invest more when the threat of entry declines because reduced entry threat improves the likelihood of rent appropriation from increased investments.

To more directly test the conjecture that underinvestment is due to firms' reduced need for entry barriers (and not because of management forecasts), I construct an indicator variable, EntryThreat_HPP, that takes one if a firm's fluidity (firm-year level entry threat measure from Hoberg, Phillips, and Prabhala [2014]) is greater than industry-year median, zero otherwise.

\footnotetext{
22 This analysis is at the firm-executive-year level. In untabulated analysis, I take the average of delta, vega, and inside equity at the firm-year level and rerun the regression. Inferences remain unchanged.
} 
Further, I rank firms based on accumulated capital expenditures, SGA, and patents in the previous five years, based on the intuition that firms that have previously invested heavily in capital expenditures, SGA, and R\&D are in less need of making such investments to deter entry. EntryThreat_Investment equals one if a firm's total investments in SGA, R\&D, and CAPEX in the previous five years are greater than the industry-year median, zero otherwise. I interact both measures of entry threat with IDD to test for the differential impact of IDD based on firms' need to invest in entry barrier. However, as seen in Table 13, Panel B, the interaction terms do not load significantly, suggesting that IDD does not affect firm investments through the channel of firms' need to create entry barrier.

\subsection{Other Alternative Explanations}

IDD may worsen top executives' career concerns as they now incur greater switching costs to

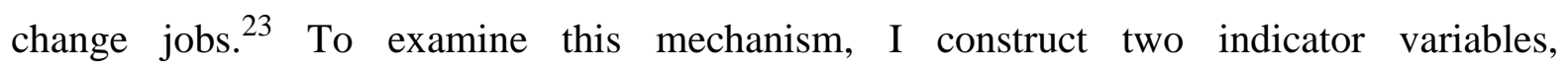
FiringPay_High and ControlPay_High, which take one if the amount of payment the CEO receives (scaled by firm's market capitalization) in the event of involuntary termination and change of control respectively is higher than the industry-year median, zero otherwise. The intuition is that CEO career concerns should be less prominent for CEOs who are costlier to fire. I interact these two variables with IDD to examine whether the adverse effect of IDD on

23 Cziraki and Groen-Xu (2017) suggest that CEO career concern increases as turnover likelihood increases, leading to less risk-taking. Because IDD reduces employee mobility, CEO turnover likelihood following the state adoption of IDD is likely to decrease. I further note that an overwhelming majority of CFOs in Graham et al. (2005)'s survey suggests that the need for hitting earnings targets is primarily driven by the desire for labormarket mobility. Since the chance of labor-market mobility reduces following the state adoption of IDD, the need for hitting earnings targets by underinvesting is likely to be reduced and the need for long-term value creation may be more important. Thus, career concerns are unlikely to explain the evidence in this thesis. 
investment is more pronounced if CEO career concerns are greater. However, the interaction terms do not load, implying that CEO career concerns are unlikely to explain the results (Table 13, Panel C).

I next examine whether changes in investment opportunity sets could drive the reduction in investments following the state adoption of IDD. I follow Asker et al. (2015) to test the investment efficiency hypothesis by using exogenous changes in state tax increases (decreases) as negative (positive) shocks to investment opportunities at the state level. The investment efficiency hypothesis implies that firms increase investments when investment opportunities are greater and vice versa. As result, when state tax increases (decreases), the negative effect of IDD on investments is likely to be higher (lower). I test this prediction by interacting indicator variables for tax increases/decreases with IDD. I do not find evidence supporting investment efficiency hypothesis (Table 13, Panels D1 \& D2).

It is possible that some of the control variables included in the main analyses could themselves be directly and indirectly affected by IDD. For example, analyst forecasts are likely to be affected by the adoption of IDD if management forecasts positively/negatively affect analyst forecasts. To mitigate the concern that the 2SLS estimates could be sensitive to the inclusion/exclusion of control variables, I drop all time-varying controls except for Size, Sizesquared, and Age, which are less likely to be affected by the adoption of IDD. ${ }^{24}$ Table 14 shows that inferences continue to hold, and the coefficient magnitudes are not materially different from those in Table 4.

\footnotetext{
${ }^{24}$ Inferences are unaffected if I drop all time-varying controls including Size, Size-Squared, and Age.
} 
Investments in long-term projects are likely to be affected by industry conditions. For example, the threat of entry, potential growth opportunities, and industry demand/supply shocks all may influence firms' investment decisions. To control for time-varying industry conditions that could potentially affect the 2 SLS estimates, I include Industry $\times$ Year fixed effects at the Fama-French 48 industry level. To control for local economic conditions, I follow Bertrand and Mullainathan (2003) and include the state-year mean of the dependent variables (State-Year Shocks), calculated as the average of SGA, R\&D, and CAPEX respectively for all firms in a state for the fiscal year, except the firm itself. ${ }^{25}$ As seen in Table 15, the coefficient estimates continue to be significant, and inferences remain unaffected.

Firms may face greater difficulty in attracting new talent following the state adoption of IDD. While IDD helps retain existing employees, prospective employees may consider employment in IDD-adopting states less attractive because it reduces their future employment opportunities and thus may adversely affect their lifetime income. IDD may also demotivate existing employees from exerting effort to develop their human capital. One could argue that since employees have fewer outside options following the state adoption of IDD, they would work harder to stay with their existing employer. Further, this channel does not fit the patterns in the cross-sectional and falsification analyses. More importantly, from the firms' perspective, IDD affords an option to sue employees who leave with trade secrets, but firms are not obligated to follow this course. Instead, treatment firms could use contracting mechanisms to

\footnotetext{
25 The intuition is that if some time-varying local economic conditions affect firm investments, such factors should affect the average of all firms in the state. Thus, controlling for state-year means accounts for time-varying local conditions.
} 
circumvent the costs of IDD if IDD hurts them. To illustrate, suppose firms face difficulty in attracting new talent in the long run following the state adoption of IDD, and this adversely affects firm performance. Assuming firms act rationally, they will see that IDD is hurting their performance and will commit to not suing new hires when they leave by including such a clause in the employment contract. This will allow firms to better retain existing employees but will not affect the acquisition of new talent. Further, if existing employees feel demotivated, firms can signal their intention not to hinder employee mobility. In other words, if labor mechanism hurts firm performance in the long run, firms and employees alike have incentives to deviate from such an equilibrium. Therefore, the labor mechanism channel is unlikely to be sustained in long-run equilibrium. 


\section{Chapter 9}

\section{Earnings Guidance and Accrual Earnings Management}

The evidence in this thesis so far suggests that annual earnings guidance induces managers to engage in myopic actions that lead to gradual shareholder wealth destruction. A related inquiry is whether managers also engage in accounting accruals manipulations to meet earnings targets set through earnings guidance. To the extent that accruals manipulation does not lead to changes in actual cash flows, accruals earnings management may be preferable to real earnings management from the shareholders' perspectives. Further, managers may engage in accruals manipulations once uncertainty about meeting earnings targets resolve at the end of the period, by which time changing real operations is no longer feasible. As a result, managers enjoy greater flexibility and discretion in altering accounting accruals.

On the other hand, the survey evidence in Graham et al. (2005) shows that managers resort to myopic underinvestment rather than accruals management to meet guided targets. This is because accounting-based manipulation runs greater risk of detection by auditors, investors, and analysts. Managers may also be subject to significant litigation risk if they engage in accruals management. Further, market participants may find it easier to unwind accrual earnings management than real earnings management (Kothari, Mizik, and Roychowdhury 2016). Therefore, managers may incur a greater private cost from accruals earnings management than real earnings management (Roychowdhury 2006).

In this chapter, I examine how annual earnings guidance affects accrual earnings 
management. I measure accruals earnings manipulation by DAC and TAC. DAC stands for discretionary accruals, which is calculated following Kothari, Leone, and Wasley (2005). I derive nondiscretionary accruals by running industry-year regression at the SIC two-digit level with at least ten observations in each industry-year group. DAC is a sharp measure of earnings management by accruals manipulation. However, it may contain significant measurement errors. I also use TAC (total accruals), which equals income before extraordinary items minus cash flow from operations. Because TAC is a model-free measure of accrual manipulation, it has less measurement error but is less sharp than DAC. Collectively, both measures complement each other to mitigate concerns about sharpness of measure and measurement errors.

Table 16 reports the results. Columns (1)-(2) show the OLS results. I find a modest decrease in discretionary accruals but no discernible changes in total accruals. While OLS results are not conclusive, 2SLS estimates in Columns (3)-(4) show no statistically significant effect of an increase in annual guidance on accruals earnings management. As a result, earnings guidance does not affect accruals earnings manipulation. To compare this evidence with prior literature, Acito (2011) does not find evidence of guiding and non-guiding firms' differential propensity to manage earnings. Kasznik (1999) find that annual management forecast error and accruals earnings management are positively associated.

The evidence in this chapter suggests that managers may be more concerned about the private cost of accruals manipulations when choosing between accruals and real earnings management. However, this could also be due to the sample period (1994-2001) I examine in this thesis. Graham et al. (2005) suggests that the private cost of accruals management for managers has increased significantly since the early 2000s, which largely overlaps with the sample period in this thesis. 


\section{Chapter 10}

\section{Asymptotic Bias of IV Estimation}

The evidence supporting the exclusion restriction strongly suggests that IDD is likely to be a valid instrument for annual earnings guidance. More importantly, the falsification analyses imply that if IDD violates the exclusion restriction, it likely biases the inferences against the direction I observe. To further examine the validity of IV estimation, I use the economic argument that all competitive advantages approach zero as the number of firms approaches infinity. This allows me to show that IDD is asymptotically unbiased as an instrument for annual earnings guidance.

Consider Eq. (1) below. I am interested in estimating the effect of annual earnings guidance on investments as proxied by SGA, R\&D, and CAPEX. Since annual earnings guidance is endogenous, I use Inevitable Disclosure Doctrine (IDD) as an instrument. Both equations are demeaned at the firm and year level such that firm fixed effects and year fixed effects are differenced out.

$$
\begin{aligned}
& \text { Investment }_{i t}=\beta^{\text {True }} \text { Annual_Guidance } i t+\varepsilon_{i t} \\
& \text { Annual_Guidance }_{i t}=\partial I D D_{i t}+\omega_{i t}
\end{aligned}
$$

For expositional purposes, write

$$
\begin{gathered}
\text { Investment }_{i t}=\beta^{\text {True }} \text { Annual_Guidance }_{i t}+\rho I D D_{i t}+\vartheta_{i t} \\
\text { where } \varepsilon_{i t}=\rho I D D_{i t}+\vartheta_{i t} \text { and Cov }\left(\mathrm{IDD}, \vartheta_{i t}\right)=0 .
\end{gathered}
$$


The exclusion restriction is equivalent to the assumption that $\rho=0$. To evaluate the asymptotic bias of IV estimates, suppose the exclusion restriction is violated such that $\rho=$ $\rho^{0} \neq 0$, where $\rho^{0}$ is the extent by which the exclusion restriction is violated (the violation coefficient).

The IV estimate is given by, $\beta^{I V}=\frac{\operatorname{Cov}(\text { Investment, } I D D)}{\operatorname{Cov}(\text { Annual_Guidance, } I D D)}$

$$
\begin{gathered}
=\frac{\operatorname{Cov}\left(\beta^{\text {True }} \text { Annual_Guidance }+\rho^{0} I D D+\vartheta_{i t}, I D D\right)}{\operatorname{Cov}(\text { Annual_Guidance, } I D D)} \\
=\frac{\operatorname{Cov}\left(\beta^{\text {True }} \text { Annual_Guidance, } I D D\right)}{\operatorname{Cov}(\text { Annual_Guidance, IDD })}+ \\
\frac{\operatorname{Cov}\left(\rho^{0} I D D, \text { IDD }\right)}{\operatorname{Cov}(\text { Annual_Guidance, IDD })} \\
=\beta^{\text {True }}+\rho^{0} \frac{\operatorname{Cov}(I D D, I D D)}{\operatorname{Cov}(\text { Annual_Guidance, IDD) }} \\
=\beta^{\text {True }}+\frac{\rho^{0}}{\partial}
\end{gathered}
$$

Eq. (4) indicates that when the instrument IDD violates the exclusion restriction, the IV estimate $\beta^{I V}$ is biased and the bias is given by $\frac{\rho^{0}}{\partial}$, which is the ratio of violation coefficient to the first stage coefficient. ${ }^{26}$ The bias $\frac{\rho^{0}}{\partial}$ in Eq. (4) has two terms, the numerator $\left(\rho^{0}\right)$ and the denominator $(\partial)$.

First, consider the denominator $(\partial)$, which is the first-stage coefficient in Eq. (2). Eq.

\footnotetext{
${ }^{26}$ I do not include time-varying controls in this derivation for expositional purpose. But the intuition carries through when one has time-varying controls in the model. See Conley, Hansen, and Rossi (2012) for a more rigorous treatment of the matter.
} 
(4) suggests that the stronger ( $\partial$ ), the less biased the IV estimate is. I have shown in Chapter 5 that IDD strongly affects annual earnings guidance both in terms of economic magnitudes and statistical significance. I also provide Angrist-Pischke F-statistics for a weak instrument test, which also suggest that IDD is a strong instrument for annual earnings guidance. This suggests that potential bias in 2SLS estimates that arises from having a weak instrument is mitigated.

Second, if the numerator $\left(\rho^{0}\right)$ converges to zero as the sample size increases, then $\beta^{I V}$ converges to $\beta^{\text {True }}$, making $\beta^{I V}$ asymptotically unbiased. To conceptualize how $\rho^{0}$ behaves as the sample size increases, note that $\rho^{0}$ represents how IDD should affect investments in SGA, R\&D and CAPEX in the absence of its effect through earnings guidance. Evidence from falsification analyses in Chapter 7, Section 7.3, suggests that shareholders expect improved returns from investments following the state adoption of IDD. As such, the optimal level of investments increases from shareholders' perspectives following the state adoption of IDD. This is further supported by evidence in prior literature (Autor, Kerr, and Kugler 2007; Jeffers 2016). Thus, $\rho^{0}$ represents the competitive advantages (and the resultant abnormal profits) that increased protection of trade secrets and retention of key employees give to the treatment firms.

To derive the asymptotic bias of the IV estimate, I make the assumption that all competitive advantages approach zero as the number of firms (and sample size) increases. That is, as the market becomes more and more competitive, no single firm expects to earn abnormal profits from its investments. This means that as the sample size approaches infinity, $\rho^{0}$ tends to zero, and $\beta^{I V}$ approaches $\beta^{\text {True }}$. Therefore, the asymptotic bias of IDD as an IV for annual guidance goes to zero, resulting in a consistent IV estimator. 


\section{Chapter 11}

\section{Conclusion}

I explore how numerical annual forecasts affect managerial short-termism. To sharpen the causal inferences, I rely on exogenous shocks to firms' incentives to issue forecasts and provide evidence indicating that numerical annual forecasts induce managers to engage in myopic investment behavior to meet earnings targets set by their own forecasts.

Why would firms issue earnings guidance if it induces managerial myopia? One explanation could be that the costs of adverse selection, if managers do not issue guidance, manifest much earlier than the costs of myopic underinvestment that show up gradually in the long run (see Table 6). In particular, stock prices take nearly three years to fully adjust to the cost of underinvestment, which is consistent with investment uncertainty resolving gradually or investors failing to fully appreciate the value-destroying implications of myopic underinvestment in a timely manner (Kothari, Mizik, and Roychowdhury 2016b; Bhojraj et al. 2009). Alternatively, when firms stop guidance to focus on long-term goals, investors assume that managers are attempting to hide bad news. For instance, Chen, Matsumoto, and Rajgopal (2011) observe that when managers stop issuing earnings guidance, the market reacts negatively. These arguments suggest that the immediate benefits of earnings guidance from some managers' perspectives could outweigh the long-term cost of myopic underinvestment. This is supported by the cross-sectional evidence in Table 7, Panel A, which shows that the 
effect of IDD on annual guidance is stronger when managers are more exposed to the cost of adverse selection. For such managers, issuing earnings guidance is likely to be a utilitymaximizing decision.

Overall, I provide robust evidence that the practice of issuing annual earnings guidance may encourage managers to be short-termist in their investment decisions. Prior studies do not generally find a robust link between quarterly earnings guidance and short-termism. The results in this thesis, coupled with prior studies on quarterly guidance, contradict some practitioners' suggestions that replacing quarterly forecasts with annual forecasts will shift managers' focus to long-term goals.

This study's findings, however, relate to a very specific disclosure practice-numerical annual earnings guidance. Firms issue various types of guidance including non-earnings, qualitative, and quarterly guidance. Besides different forms of guidance, firms also provide an overwhelming amount of mandatory and voluntary disclosure. The implications of this thesis do not necessarily extend to other non-earnings guidance or other forms of disclosure. 


\section{References}

Acito, Andrew. 2011. "Does Quarterly Earnings Guidance Increase or Reduce Earnings Management?" Working Paper, The University of Iowa.

Aghion, Philippe, Nicholas Bloom, Richard Blundell, Rachel Griffith, and Peter Howitt. 2005. "Competition and Innovation: An Inverted-U Relationship." Quarterly Journal of Economics 120 (2).

Ali, Ashiq, Sandy Klasa, and P. Eric Yeung. 2014. "Industry Concentration and Corporate Disclosure Policy." Journal of Accounting and Economics 58: 240-64.

Ali, Ashiq, and Weining Zhang. 2015. "CEO Tenure and Earnings Management." Journal of Accounting and Economics 59 (1). Elsevier: 60-79.

Almeling, David. 2012. "Seven Reasons Why Trade Secrets Are Increasingly Important." Berkeley Technology Law Journal 27 (2): 1091-1118.

Angrist, Joshua, and Alan Krueger. 2001. "Instrumental Variables and the Search for Identification: From Supply and Demand to Natural Experiments." Journal of Economic Perspectives 15 (4): 69-85.

Angrist, Joshua, and Jorn-Steffen Pischke. 2009. Mostly Harmless Econometrics: An Empiricist's Companion. Princeton University Press.

Anilowski, Carol, Mei Feng, and Douglas J. Skinner. 2007. "Does Earnings Guidance Affect Market Returns? The Nature and Information Content of Aggregate Earnings Guidance.” Journal of Accounting and Economics 44 (1-2): 36-63.

Aobdia, Daniel. 2018. "Employee Mobility, Noncompete Agreements, Product-Market Competition, and Company Disclosure." Review of Accounting Studies 23 (1): 296-346.

Asker, John, Joan Farre-mensa, and Alexander Ljungqvist. 2015. "Corporate Investment and Stock Market Listing: A Puzzle?" Review of Financial Studies 28 (2): 342-90.

Atanasov, Vladimir, and Bernard Black. 2017. "The Trouble with Instruments : Re-Examining 
Shock-Based IV Designs." Northwestern Law \& Econ Research Paper 16-01, Northwestern Public Law Research Paper No. 15-26.

Autor, David H, William Kerr, and Adriana Kugler. 2007. "Does Employment Protection Reduce Productivity? Evidence From US States.” The Economic Journal 117 (June): F189-F217.

Baginski, Stephen, and Kenneth Rakow. 2012. "Management Earnings Forecast Disclosure Policy and the Cost of Equity Capital." Review of Accounting Studies 17 (2): 279-321.

Baik, Bok, David Farber, and Sam Lee. 2011. "CEO Ability and Management Earnings Forecasts." Contemporary Accounting Research 28 (5): 1645-68.

Balakrishnan, Karthik, Mary Brooke Billings, Bryan Kelly, and Alexander Ljungqvist. 2014. "Shaping Liquidity : On the Causal Effects of Voluntary Disclosure." Journal of Finance.

Bergman, Nittai K, and Sugata Roychowdhury. 2008. "Investor Sentiment and Corporate Disclosure.” Journal of Accounting Research 46 (5).

Bertrand, Marianne, and Sendhil Mullainathan. 2003. "Enjoying the Quiet Life? Corporate Governance and Managerial Preferences." Journal of Political Economy 111 (5): 104375.

Bhojraj, Sanjeev, Paul Hribar, Marc Picconi, and John Mcinnis. 2009. "Making Sense of Cents : An Examination of Firms That Marginally Miss or Beat Analyst Forecasts." Journal of Finance 64 (5): 2361-88.

Billings, Mary Brooke, and Matthew C. Cedergren. 2015. "Strategic Silence, Insider Selling and Litigation Risk." Journal of Accounting and Economics 59 (2-3). Elsevier: 119-42.

Billings, Mary, Robert Jennings, and Baruch Lev. 2015. "On Guidance and Volatility." Journal of Accounting and Economics 60 (2-3). Elsevier: 161-80.

Bova, Francesco. 2013. "Labor Unions and Management's Incentive to Signal a Negative Outlook." Contemporary Accounting Research 30 (1): 14-41. 
Bova, Francesco, Yiwei Dou, and Ole-Kristian Hope. 2015. "Employee Ownership and Firm Disclosure." Contemporary Accounting Research 32 (2): 639-73.

Bozanic, Zahn, Darren Roulstone, and Andrew Van Buskirk. 2018. "Management Earnings Forecasts and Other Forward-Looking Statements." Journal of Accounting and Economics 65 (1): 1-20.

Call, Andrew, Shuping Chen, Adam Esplin, and Bin Miao. 2015. "Does Long-Term Earnings Guidance Mitigate Managerial Myopia?" Working Paper, Arizona State University, University of Texas at Austin, University of Alberta, National University of Singapore.

Call, Andrew, Shuping Chen, Bin Miao, and Yen Tong. 2014. "Short-Term Earnings Guidance and Accrual-Based Earnings Management.” Review of Accounting Studies 19 (2): 95587.

Chen, Deqiu, Huasheng Gao, and Yujing Ma. 2017. "Human Capital Driven Acquisition: Evidence from the Inevitable Disclosure Doctrine." Working Paper, University of International Business and Economics, Nanyang Business School.

Chen, Shuping, Kelly Huang, and Brent Lao. 2015. "Is Earnings Guidance Associated with Less Firm Innovation?" Working Paper, University of Texas at Austin, Florida International University.

Chen, Shuping, Dawn Matsumoto, and Shiva Rajgopal. 2011. "Is Silence Golden? An Empirical Analysis of Firms That Stop Giving Quarterly Earnings Guidance.” Journal of Accounting and Economics 51 (1-2): 134-50.

Cheng, Mei, K. R. Subramanyam, and Yuan Zhang. 2007. "Earnings Guidance and Managerial Myopia." Working Paper, University of Arizona, University of Southern California, Columbia University.

Chuk, Elizabeth, Dawn Matsumoto, and Gregory S. Miller. 2013. "Assessing Methods of Identifying Management Forecasts: CIG vs. Researcher Collected." Journal of Accounting and Economics 55 (1). Elsevier: 23-42. 
Chung, Richard, Bryan Byung-Hee Lee, Woo-Jong Lee, and Byungcherl Charlie Sohn. 2015. “Do Managers Withhold Good News from Labor Unions?” Management Science 62 (1).

Clement, Michael, Richard Frankel, and Jeffrey Miller. 2003. "Confirming Management Earnings Forecasts, Earnings Uncertainty, and Stock Returns.” Journal of Accounting Research 41 (4).

Cohen, Wesley, Richard Nelson, and John Walsh. 2000. "Protecting Their Intellectual Assets: Appropriability Conditions and Why U.S. Manufacturing Firms Patent (or Not)." NBER Working Paper Series 7552.

Coles, Jeffrey L., Naveen D. Daniel, and Lalitha Naveen. 2006. "Managerial Incentives and Risk-Taking.” Journal of Financial Economics 79 (2): 431-68.

Coller, Maribeth, and Teri Lombardi Yohn. 1997. "Management Forecasts and Information Asymmetry: An Examination of Bid-Ask Spreads." Journal of Accounting Research 35 (2): 181-91.

Commission on the Regulation of U.S. Capital Markets in the 21st Century. 2007. "Report and Recommendations." U.S. Chamber of Commerce.

Conley, Timothy, Christian Hansen, and Peter Rossi. 2012. "Plausibly Exogenous." Review of Economics and Statistics 94 (1): 260-72.

Core, John, and Wayne Guay. 2002. "Estimating the Value of Stock Option Portfolios and Their Sensitivities to Price and Volatility." Journal of Accounting Research 40 (3): 61340 .

Cotter, Julie, Irem Tuna, and Peter Wysocki. 2006. "Expectations Management and Beatable Targets: How Do Analysts React to Explicit Earnings Guidance?" Contemporary Accounting Research 23 (3): 593-624.

Edmans, Alex, Mirko S. Heinle, and Chong Huang. 2016. "The Real Costs of Financial Efficiency When Some Information Is Soft." Review of Finance 20 (6): 2151-82. 
Forester Consulting. 2010. "The Value Of Corporate Secrets."

Frésard, Laurent, and Philip Valta. 2016. "How Does Corporate Investment Respond to Increased Entry Threat?" Review of Corporate Finance Studies 5 (1).

Gibbons, Robert, and Kevin J Murphy. 1992. "Optimal Incentive Contracts in the Presence of Career Concerns: Theory and Evidence.” Journal of Political Economy 100 (3): 468-505.

Gigler, Frank, Chandra Kanodia, Haresh Sapra, and Raghu Venugopalan. 2014. "How Frequent Financial Reporting Can Cause Managerial Short-Termism: An Analysis of the Costs and Benefits of Increasing Reporting Frequency." Journal of Accounting Research 52 (2): $357-87$.

Giroud, Xavier, and Holger M. Mueller. 2010. "Does Corporate Governance Matter in Competitive Industries?” Journal of Financial Economics 95 (3). Elsevier: 312-31.

Graham, John, Campbell Harvey, and Shiva Rajgopal. 2005. "The Economic Implications of Corporate Financial Reporting." Journal of Accounting and Economics 40 (1-3): 3-73.

Hall, Bronwyn, and Josh Lerner. 2010. The Financing of $R \& D$ and Innovation. Handbook of the Economics of Innovation. Elsevier-North Holland.

Hilary, Gilles. 2006. "Organized Labor and Information Asymmetry in the Financial Markets.” Review of Accounting Studies 11 (4): 525-48.

Hoberg, Gerard, Gordon Phillips, and Nagpurnanand Prabhala. 2014. "Product Market Threats, Payouts, and Financial Flexibility." Journal of Finance LXIX (1).

Houston, Joel, Baruch Lev, and Jennifer Tucker. 2010. "To Guide or Not to Guide? Causes and Consequences of Stopping Quarterly Earnings Guidance." Contemporary Accounting Research 27 (1): 143-85.

Jeffers, Jessica. 2016. “The Impact of Restricting Labor Mobility on Corporate Investment and Entrepreneurship." Working Paper, University of Chicago Booth School of Business. 
Karageorgiou, Gabriel, and George Serafeim. 2014. "Earnings Guidance - Part of the Future or the Past?" Generation Foundation Report.

Kasznik, Ron. 1999. "On the Association between Voluntary Disclosure and Earnings Management.” Journal of Accounting Research 37 (1): 57-81.

Kim, Yongtae, and Myung Seok. 2012. “Are All Management Earnings Forecasts Created Equal? Expectations Management versus Communication.” Review of Accounting Studies 17 (4): 807-47.

Kim, Yongtae, Lixin Su, and Xindong Zhu. 2017. "Does Quarterly Earnings Guidance Cessation Reduce Investors' Short-Termism?” Review of Accounting Studies 22 (2): 71552.

Klasa, Sandy, Hernan Ortiz-Molina, Matthew Serfling, and Shweta Srinivasan. 2017. "Protection of Trade Secrets and Capital Structure Decisions." Working Paper, University of Arizona, University of British Columbia.

Kleiner, Morris, and Marvin Bouillon. 1988. "Providing Business Information to Production Workers: Correlates of Compensation and Profitability.” In ILR Review, 41:605-17. Sage Publications, Inc.

Kogan, Leonid, Dimitris Papanikolaou, Amit Seru, and Noah Stoffman. 2017. "Technological Innovation, Resource Allocation, and Growth." Quarterly Journal of Economics 132 (2): $665-712$.

Kothari, S. P., Natalie Mizik, and Sugata Roychowdhury. 2016a. "Managing for the Moment: The Role of Earnings Management via Real Activities versus Accruals in SEO Valuation.” Journal of Accounting and Economics 91 (2): 559-86.

Kothari, S.P., Natalie Mizik, and Sugata Roychowdhury. 2016b. "Managing for the Moment: The Role of Earnings Management via Real Activities versus Accruals in SEO Valuation." The Accounting Review 91 (2): 559-86. 
Kraft, Arthur, Rahul Vashishtha, and Mohan Venkatachalam. 2018. "Frequent Financial Reporting and Managerial Myopia.” The Accounting Review 93 (2): 249-75.

Ladika, Tomislav, and Zacharias Sautner. 2014. "The Effect of Managerial Short-Termism on Corporate Investment.” Working Paper, University of Amsterdam.

Lang, Mark, and Edward Sul. 2014. "Linking Industry Concentration to Proprietary Costs and Disclosure." Journal of Accounting \& Economics 58 (2-3).

Lao, Yi. 2013. "Does Earnings Guidance Contribute to Investor Short-Termism?” PhD Dissertation, University of Texas at Austin.

Lee, Sam, Steven R. Matsunaga, and Chul W. Park. 2012. "Management Forecast Accuracy and CEO Turnover.” Accounting Review 87 (6): 2095-2122.

Li, Xi. 2010. "The Impacts of Product Market Competition on the Quantity and Quality of Voluntary Disclosures." Review of Accounting Studies 15 (3): 663-711.

Li, Yinghua, Yupeng Lin, and Liandong Zhang. 2018. "Trade Secrets Law and Corporate Disclosure: Causal Evidence on the Proprietary Cost Hypothesis." Journal of Accounting Research 56 (1): 265-308.

Lin, Chen, Lai Wei, and Haibin Wu. 2016. "Operational Uncertainty and Managerial Incentives in Information Production." Working Paper, University of Hong Kong, Lingnan University, City University of Hong Kong.

Mackinnon, James, and Matthew Webb. 2017. "Wild Bootstrap Inference for Wildly Different Cluster Sizes.” Journal of Applied Econometrics 32 (2): 233-54.

Michenaud, Sebastien. 2008. “Corporate Investment and Analyst Pressure.” Paris December 2007 Finance International Meeting AFFI-EUROFIDAI Paper.

Narayanan, M. P. 1985. “Managerial Incentives for Short-Term Results.” Journal of Finance 40 (5): 1469-84. 
NIRI Analytics. 2016. "National Investor Relations Institute Earnings Process Practices Research Report."

Reynolds, L.G., S.H. Masters, and C.H. Moser. 1998. Labor Economics and Labor Relations. 11th ed. Prentice Hall.

Roychowdhury, Sugata. 2006. "Earnings Management through Real Activities Manipulation." Journal of Accounting and Economics 42 (3): 335-70.

Samila, Sampsa, and Olav Sorenson. 2011. "Noncompete Covenants: Incentives to Innovate or Impediments to Growth." Management Science 57 (3): 425-38.

Scott, Thomas. 1994. "Incentives and Disincentives for Financial Disclosure: Voluntary Disclosure of Defined Benefit Pension Plan Information by Canadian Firms." The Accounting Review 69 (1): 26-43.

Securities and Exchange Commission. 1994. "Safe Harbor For Forward-Looking Statements." Release No. 33-7101.

Shroff, Nemit, Amy Sun, Hal White, and Weining Zhang. 2013. "Voluntary Disclosure and Information Asymmetry: Evidence from the 2005 Securities Offering Reform.” Journal of Accounting Research 51 (5).

Skinner, Douglas. 1997. "Earnings Disclosures and Stockholder Lawsuits." Journal of Accounting and Economics 23: 249-82.

Skinner, Douglas J. 1995. "Do the SEC's Safe Harbor Provisions Encourage Forward-Looking Disclosures?" Financial Analysts Journal 51 (4): 38-44.

Stein, Jeremy. 1988. "Takeover Threats and Managerial Myopia." Journal of Political Economy 96 (1): 61-80.

— 1989. "Efficient Capital Markets, Inefficient Firms: A Model of Myopic Corporate Behavior." The Quarterly Journal of Economics 104 (4): 655-69. 
-2003. Agency, Information and Corporate Investment. Handbook of the Economics of Finance. Vol. 1. Elsevier Science B.V.

Tang, Michael, Li Yao, and Paul Zarowin. 2015. “Once Is Not Enough: The Determinants and Consequences of Management Updates of Annual Forecasts.” Working Paper, New York University, Concordia University.

Trueman, Brett. 1986. "Why Do Managers Voluntarily Release Earnings Forecasts?” Journal of Accounting and Economics 8 (1): 53-71.

U.S. Department of the Treasury. 2016. "Non-Compete Contracts : Economic Effects and Policy Implications."

Verrecchia, Robert E. 1983. "Discretionary Disclosure." Journal of Accounting and Economics 5: 179-94.

Waymire, Gregory. 1985. "Earnings Volatility and Voluntary Management Forecast Disclosure." Journal of Accounting Research 23 (1): 268-95. 


\section{Appendices}

\section{Appendix A: Inevitable Disclosure Doctrine Adoption/Rejection}

I. State Adoption of Inevitable Disclosure Doctrine - Main Sample (1994-2011)

\begin{tabular}{|c|c|}
\hline State & Year Adopted (Rejected) \\
\hline $\mathrm{AR}$ & 1997 \\
\hline CT & 1996 \\
\hline GA & 1998 \\
\hline IN & 1995 \\
\hline IA & 1996 \\
\hline $\mathrm{KS}$ & 2006 \\
\hline MI & (2002) \\
\hline MO & 2000 \\
\hline $\mathrm{OH}$ & 2000 \\
\hline FL & 2001 \\
\hline $\mathrm{TX}$ & (2003) \\
\hline UT & 1998 \\
\hline WA & 1997 \\
\hline
\end{tabular}


II. State Adoption of Inevitable Disclosure Doctrine - Falsification Analyses Sample (19801990)

\begin{tabular}{cc}
\hline State & Year Adopted \\
\hline IL & 1989 \\
MN & 1986 \\
NJ & 1987 \\
PA & 1982 \\
\hline
\end{tabular}


Appendix B: Variable Definitions

\begin{tabular}{|c|c|}
\hline Variables & Definitions \\
\hline \multicolumn{2}{|c|}{$\underline{\text { Main Outcome Variables }}$} \\
\hline SGA & $\begin{array}{l}\text { Selling, General, and Administrative Expenses plus Advertising } \\
\text { Expenses scaled by total book assets, set to zero if missing }\end{array}$ \\
\hline$R \& D$ & $\begin{array}{l}R \& D \text { expenditures scaled by the book value of assets, set to zero } \\
\text { if missing }\end{array}$ \\
\hline CAPEX & $\begin{array}{l}\text { Capital Expenditures scaled by the book value of assets, set to zero } \\
\text { if missing }\end{array}$ \\
\hline \multicolumn{2}{|c|}{ Other Outcome Variables } \\
\hline$\underline{\log P r e c i s i o n}$ & $\begin{array}{l}\text { Logarithm of (one plus) the average precision of all earnings } \\
\text { guidance in a fiscal year. Precision for a forecast equals } 3 \text { if it is a } \\
\text { point forecast, } 2 \text { if it is range forecast, } 1 \text { if it is a } \\
\text { minimum/maximum, or qualitative and zero otherwise. }\end{array}$ \\
\hline$\underline{\log T i m e l i n e s s}$ & $\begin{array}{l}\text { Logarithm of (one plus) the average timeliness of all forecasts } \\
\text { Timeliness for a forecast is the number of days between the } \\
\text { forecast and the end of reporting period. }\end{array}$ \\
\hline$\underline{\text { RevGrowth }}$ & Year-on-year revenue growth \\
\hline$\underline{\log P a t e n t}$ & $\begin{array}{l}\text { Logarithm of (one plus) number of patents a firm receives in a } \\
\text { fiscal year. }\end{array}$ \\
\hline$\underline{\log C i t e}$ & $\begin{array}{l}\text { Logarithm of (one plus) number of citations a firm's paten } \\
\text { receives in subsequent years. }\end{array}$ \\
\hline Return & Annual raw returns for the fiscal year. \\
\hline
\end{tabular}




\begin{tabular}{|c|c|}
\hline DAC & $\begin{array}{l}\text { Income-increasing discretionary accrual proxy calculated } \\
\text { following Kothari, Leone, and Wasley (2005). }\end{array}$ \\
\hline TAC & $\begin{array}{l}\text { Income-increasing total accruals, equals }(i b-\text { oancf) after } 1988 \\
\text { and }(\Delta a c t-\Delta c h e-\Delta l c t+\Delta d l c-d p) \text { before } 1988 \text { from Compustat. } \\
\Delta \mathrm{X} \text { represents changes in } \mathrm{X} \text { from last year. All variables are scaled } \\
\text { by lagged total assets. }\end{array}$ \\
\hline Meet or Beat & $\begin{array}{l}\text { An indicator variable that equals one if firms meet or beat annual } \\
\text { earnings guidance, zero otherwise. }\end{array}$ \\
\hline Meet or Barely Beat & $\begin{array}{l}\text { An indicator variable that equals one if firms meet or beat annual } \\
\text { earnings guidance within ten cents, zero otherwise. }\end{array}$ \\
\hline $\log$ Delta & $\begin{array}{l}\text { Logarithm of pay-performance sensitivity (delta), from Coles, } \\
\text { Daniel, and Naveen (2006), who calculate these metrics based on } \\
\text { Core and Guay (2002). }\end{array}$ \\
\hline $\log \mathrm{Vega}$ & $\begin{array}{l}\text { Logarithm of wealth-stock volatility sensitivity (vega), from } \\
\text { Coles, Daniel, and Naveen (2006), who calculate these metrics } \\
\text { based on Core and Guay (2002). }\end{array}$ \\
\hline logEquity & $\begin{array}{l}\text { Logarithm of stock- and option-portfolio value (inside equity), } \\
\text { from Coles, Daniel, and Naveen (2006), who calculate these } \\
\text { metrics based on Core and Guay (2002). }\end{array}$ \\
\hline \multicolumn{2}{|c|}{$\underline{\text { Test Variables \& Controls }}$} \\
\hline IDD & $\begin{array}{l}=1 \text { if a firm is located in a state where Inevitable Disclosure } \\
\text { Doctrine (IDD) is in force, zero otherwise }\end{array}$ \\
\hline
\end{tabular}




\begin{tabular}{|c|c|}
\hline \# of Annual Forecasts & $\begin{array}{l}\text { Number of Numerical Annual Forecasts made by the management } \\
\text { of a firm in a fiscal year. Annual forecasts refer to forecasts about } \\
\text { annual EPS. }\end{array}$ \\
\hline \# of Quarterly Forecasts & $\begin{array}{l}\text { Number of Numerical Quarterly Forecasts made by a firm in a } \\
\text { fiscal year. Quarterly forecasts refer to forecasts about quarterly } \\
\text { EPS. }\end{array}$ \\
\hline Revise_Down & $\begin{array}{l}\text { An indicator variable that takes one if firms revise down guidance } \\
\text { subsequently after having previously providing guidance early in } \\
\text { the year, zero otherwise. }\end{array}$ \\
\hline Confirm/Revise_Up & $\begin{array}{l}\text { An indicator variable that takes one if firms confirm or revise up } \\
\text { guidance subsequently after having previously providing } \\
\text { guidance early in the year, zero otherwise. }\end{array}$ \\
\hline Size & Logarithm of book value of assets \\
\hline Age & No. of years a firm is in Compustat database \\
\hline Leverage & $\begin{array}{l}\text { Total short and long-term debt scaled by the book value of assets, } \\
\text { set to missing if greater than one. }\end{array}$ \\
\hline InstOwn & $\begin{array}{l}\text { Percentage of shares held by institutional owners, set to zero for } \\
\text { missing firm-years }\end{array}$ \\
\hline \#Analyst & no. of analysts covering a firm, set to zero for missing firm-years \\
\hline Loss & $=1$ if a firm incurs a loss in a given fiscal year, zero otherwise. \\
\hline Equity & $=1$ if total equity financing is positive, zero otherwise \\
\hline EarnVol & $\begin{array}{l}\text { Earnings Volatility, calculated as the standard deviation of current } \\
\text { and last four years' EBITDA }\end{array}$ \\
\hline
\end{tabular}




\begin{tabular}{|c|c|}
\hline HHI & Herfindahl Index, measured at SIC 3-digit for sales \\
\hline Trade Secret Intensity & $\begin{array}{l}\text { An indicator variable for firms in Computers, Electronics, } \\
\text { Petroleum, Chemical, Drugs, and Scientific research and } \\
\text { development services industries. }\end{array}$ \\
\hline Close Rivals & $\begin{array}{l}\text { An indicator variable that takes one if a firm has greater than } \\
\text { Fama-French } 48 \text { industry-year median close rivals, zero } \\
\text { otherwise. }\end{array}$ \\
\hline Earnings Uncertainty & $\begin{array}{l}\text { The standard deviation of earnings at the Fama-French } 48 \\
\text { industry-year level. }\end{array}$ \\
\hline ERC & $\begin{array}{l}\text { Earnings-response coefficient estimated at the Fama-French } 48 \\
\text { industry-year level. }\end{array}$ \\
\hline CEO Tenure & The number of years the current CEO is in office. \\
\hline EntryThreat_HPP & $\begin{array}{l}\text { An indicator variable that takes one if a firm's fluidity (entry threat } \\
\text { measure from Hoberg, Phillips, and Prabhala (2014)) is greater } \\
\text { than the industry median, zero otherwise. }\end{array}$ \\
\hline EntryThreat_Investment & $\begin{array}{l}\text { An indicator variable that takes one if a firm's total investments } \\
\text { in SGA, R\&D, and CAPEX in the previous five years are greater } \\
\text { than the industry-year median, zero otherwise. }\end{array}$ \\
\hline FiringPay_High & $\begin{array}{l}\text { An indicator variable that takes one takes one if the amount of } \\
\text { payment CEO receives (scaled by firm's year-end market } \\
\text { capitalization) in the event of involuntary termination is higher } \\
\text { than the Fama-French } 48 \text { industry-year median, }\end{array}$ \\
\hline ControlPay_High & $\begin{array}{l}\text { An indicator variable that takes one takes one if the amount of } \\
\text { payment CEO receives (scaled by firm's year-end market } \\
\text { capitalization) in the event of change of control is higher than the } \\
\text { Fama-French } 48 \text { industry-year median, }\end{array}$ \\
\hline
\end{tabular}




\section{Appendix C: Figures}

Figure 1: Time-series evolution of annual and quarterly management earnings forecasts

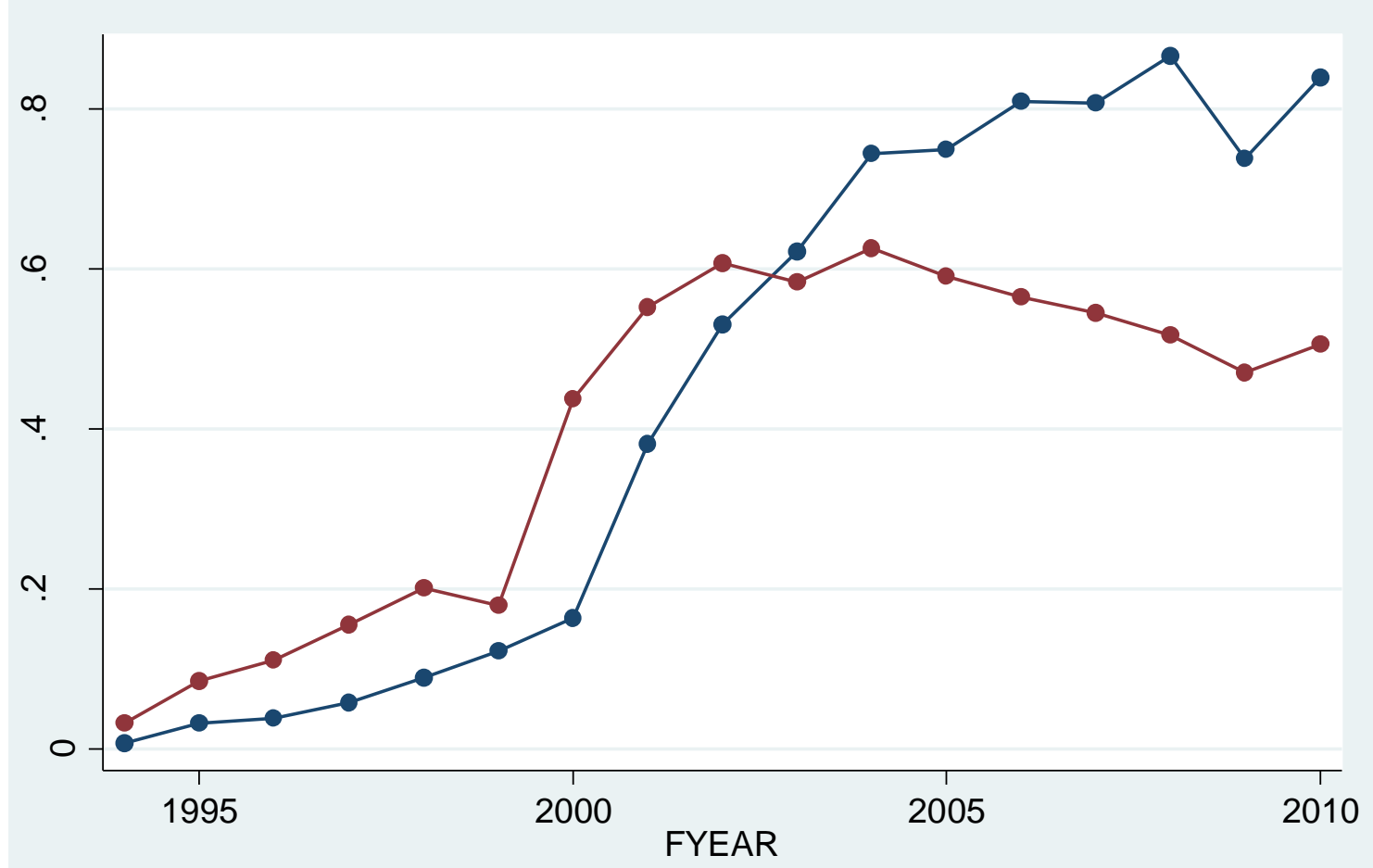

$\longrightarrow$ Annual Forecast No. per Firm $\longrightarrow$ Quarterly Forecast No. per Firm 


\section{Appendix D: Tables}

Table 1-A: Summary Statistics for Key Variables

\begin{tabular}{ccccc}
\hline Variables & N & Mean & Std. Dev & Median \\
\hline SGA & 95427 & 0.33 & 0.37 & 0.24 \\
R\&D & 95427 & 0.065 & 0.14 & 0 \\
CAPEX & 95427 & 0.057 & 0.07 & 0.04 \\
MkBk & 86626 & 2.24 & 2.31 & 1.48 \\
Guidance: Annual Frequency & 95427 & 0.39 & 1.25 & 0 \\
Guidance: Annual Incidence & 95427 & 0.12 & 0.32 & 0 \\
Guidance: Quarterly Frequency & 95427 & 0.35 & 1.09 & 0 \\
Guidance: Quarterly Incidence & 95427 & 0.13 & 0.34 & 0 \\
Book Assets (\$ millions) & 95427 & 1603 & 4604 & 150 \\
Age & 95427 & 17 & 14 & 12 \\
Leverage & 95427 & 0.23 & 0.22 & 0.19 \\
InstOwn & 95427 & 0.25 & 0.31 & 0.09 \\
\#Analyst & 95427 & 4.05 & 6.85 & 0 \\
Loss & 95427 & 0.26 & 0.44 & 0 \\
EarnVol & 95427 & 0.15 & 0.36 & 0.05 \\
HHI & 95427 & 0.17 & 0.15 & 0.12 \\
\hline
\end{tabular}

The table reports summary statistics for the main analyses. The sample period ranges from 1994 to 2011. All COMPUSTAT firms (excluding financials, firms located outside the U.S., and firm-years with less than $\$ 1$ million in book assets) are included in the sample. All continuous variables, with the exception of Age, are winsorized at the 1\% and $99 \%$ levels. See Appendix B for variable definitions. 
Table 1-B: Correlation Matrix of Key Variables

\begin{tabular}{|c|c|c|c|c|c|c|c|c|c|c|c|c|c|}
\hline & SGA & $\mathrm{R} \& \mathrm{D}$ & CAPEX & $\begin{array}{l}\text { \#Annual } \\
\text { Forecasts }\end{array}$ & Size & Age & Leverage & InstOwn & \#Analyst & Loss & Equity & EarnVol & HHI \\
\hline SGA & 1 & & & & & & & & & & & & \\
\hline $\mathrm{R} \& \mathrm{D}$ & 0.34 & 1 & & & & & & & & & & & \\
\hline CAPEX & -0.07 & -0.08 & 1 & & & & & & & & & & \\
\hline $\begin{array}{l}\text { \#Annual } \\
\text { Forecasts }\end{array}$ & -0.06 & -0.07 & -0.04 & 1 & & & & & & & & & \\
\hline Size & -0.45 & -0.31 & 0.05 & 0.27 & 1 & & & & & & & & \\
\hline Age & -0.18 & -0.19 & -0.07 & 0.20 & 0.43 & 1 & & & & & & & \\
\hline Leverage & -0.16 & -0.20 & 0.09 & 0.00 & 0.22 & 0.06 & 1 & & & & & & \\
\hline InstOwn & -0.16 & -0.09 & 0.00 & 0.31 & 0.46 & 0.23 & -0.09 & 1 & & & & & \\
\hline \#Analyst & -0.15 & -0.06 & 0.07 & 0.30 & 0.53 & 0.22 & -0.04 & 0.66 & 1 & & & & \\
\hline Loss & 0.31 & 0.43 & -0.07 & -0.15 & -0.48 & -0.26 & -0.15 & -0.26 & -0.21 & 1 & & & \\
\hline Equity & 0.10 & 0.21 & 0.05 & -0.02 & -0.15 & -0.20 & -0.12 & 0.03 & 0.00 & 0.20 & 1 & & \\
\hline EarnVol & 0.28 & 0.32 & -0.01 & -0.08 & -0.35 & -0.18 & -0.09 & -0.18 & -0.14 & 0.37 & 0.14 & 1 & \\
\hline HHI & -0.02 & -0.18 & -0.05 & 0.05 & 0.03 & 0.09 & 0.05 & 0.06 & 0.00 & -0.07 & -0.07 & -0.03 & 1 \\
\hline
\end{tabular}


Table 2: 2SLS First Stage - IDD and Management Earnings Guidance

\begin{tabular}{|c|c|c|c|c|}
\hline \multirow[b]{3}{*}{ Variables } & \multicolumn{2}{|c|}{ Annual Forecasts } & \multicolumn{2}{|c|}{ Quarterly Forecasts } \\
\hline & (1) & (2) & (3) & (4) \\
\hline & Number & Indicator & Number & Indicator \\
\hline IDD & $\begin{array}{c}0.140 * * * \\
(3.965)\end{array}$ & $\begin{array}{c}\mathbf{0 . 0 2 8 2} * * * \\
(\mathbf{3 . 8 0})\end{array}$ & $\begin{array}{c}0.039 \\
(1.125)\end{array}$ & $\begin{array}{c}0.003 \\
(0.433)\end{array}$ \\
\hline Size & $\begin{array}{c}-0.29 * * * \\
(-9.49)\end{array}$ & $\begin{array}{c}-0.03 * * * \\
(-5.03)\end{array}$ & $\begin{array}{c}-0.01 \\
(-0.74)\end{array}$ & $\begin{array}{c}0.02 * * * \\
(4.89)\end{array}$ \\
\hline Size-Squared & $\begin{array}{c}0.05^{* * * *} \\
(12.46)\end{array}$ & $\begin{array}{c}0.01 * * * \\
(9.26)\end{array}$ & $\begin{array}{c}0.01 * * * \\
(5.41)\end{array}$ & $\begin{array}{c}0.00 \\
(0.85)\end{array}$ \\
\hline Age & $\begin{array}{c}0.00 \\
(0.85)\end{array}$ & $\begin{array}{c}0.00 * * * \\
(7.56)\end{array}$ & $\begin{array}{c}-0.03 * * * \\
(-21.79)\end{array}$ & $\begin{array}{c}-0.01 * * * \\
(-22.98)\end{array}$ \\
\hline Leverage & $\begin{array}{c}-0.18 * * * \\
(-4.67)\end{array}$ & $\begin{array}{c}-0.03 * * * \\
(-3.90)\end{array}$ & $\begin{array}{c}-0.12 * * * \\
(-3.88)\end{array}$ & $\begin{array}{c}-0.03 * * * \\
(-3.64)\end{array}$ \\
\hline InstOwn & $\begin{array}{c}0.50 * * * \\
(9.59)\end{array}$ & $\begin{array}{c}0.15 * * * \\
(12.65)\end{array}$ & $\begin{array}{c}0.43 * * * \\
(9.97)\end{array}$ & $\begin{array}{c}0.15 * * * \\
(14.23)\end{array}$ \\
\hline \#Analyst & $\begin{array}{c}0.02 * * * \\
(6.80)\end{array}$ & $\begin{array}{c}0.01 * * * \\
(10.64)\end{array}$ & $\begin{array}{c}0.03 * * * \\
(12.20)\end{array}$ & $\begin{array}{c}0.01 * * * \\
(16.37)\end{array}$ \\
\hline Loss & $\begin{array}{c}-0.13 * * * \\
(-10.54)\end{array}$ & $\begin{array}{c}-0.04 * * * \\
(-11.67)\end{array}$ & $\begin{array}{c}-0.11 * * * \\
(-9.50)\end{array}$ & $\begin{array}{c}-0.03 * * * \\
(-9.39)\end{array}$ \\
\hline Equity & $\begin{array}{c}-0.02 \\
(-1.57)\end{array}$ & $\begin{array}{c}-0.00 \\
(-1.31)\end{array}$ & $\begin{array}{c}-0.04 * * * \\
(-4.15)\end{array}$ & $\begin{array}{c}-0.01 * * * \\
(-2.64)\end{array}$ \\
\hline EarnVol & $\begin{array}{c}-0.06 * * * \\
(-3.97)\end{array}$ & $\begin{array}{c}-0.02 * * * \\
(-4.16)\end{array}$ & $\begin{array}{c}-0.07 * * * \\
(-4.89)\end{array}$ & $\begin{array}{c}-0.02 * * * \\
(-4.09)\end{array}$ \\
\hline $\mathrm{HHI}$ & $\begin{array}{c}-0.28 \\
(-1.23)\end{array}$ & $\begin{array}{c}-0.07 \\
(-1.31)\end{array}$ & $\begin{array}{c}0.02 \\
(0.11)\end{array}$ & $\begin{array}{c}0.06 \\
(1.15)\end{array}$ \\
\hline HHI-Squared & $\begin{array}{c}0.34 \\
(1.23)\end{array}$ & $\begin{array}{c}0.07 \\
(1.12)\end{array}$ & $\begin{array}{c}-0.14 \\
(-0.65)\end{array}$ & $\begin{array}{c}-0.09 \\
(-1.51)\end{array}$ \\
\hline Observations & 95,427 & 95,427 & 95,427 & 95,427 \\
\hline Adj R-squared & 0.475 & 0.440 & 0.438 & 0.395 \\
\hline Firm \& Year FE & Yes & Yes & Yes & Yes \\
\hline
\end{tabular}


The table reports the OLS estimates for the effect of state adoption of Inevitable Disclosure Doctrine (IDD) on the likelihood and frequency of quarterly and annual management earnings forecasts. This constitutes the first-stage of two-stage least squares (2SLS) estimation, with the $2^{\text {nd }}$ stage given in Table 4. IDD equals one for all fiscal years greater than or equal to the IDDadoption year for firms located in adopting states, and zero otherwise. Indicator (Number) is the incidence (frequency) of quarterly/annual forecasts in a fiscal year. The sample period ranges from 1994 to 2011. Test statistics (two-sided) based on robust standard errors clustered at the firm level are reported in parenthesis. Asterisks ***,**, and * indicate statistical significance at the 1\%, 5\%, and 10\% level respectively. See Appendix B for variable definitions. 
Table 3: The Effects of IDD on Guidance Precision and Timeliness

\begin{tabular}{|c|c|c|c|c|}
\hline \multirow[b]{2}{*}{ Variables } & \multicolumn{2}{|c|}{ Annual } & \multicolumn{2}{|c|}{ Quarterly } \\
\hline & $\begin{array}{c}(1) \\
\log \text { Precision }\end{array}$ & $\begin{array}{c}(2) \\
\log \text { Timeliness }\end{array}$ & $\begin{array}{c}\text { (3) } \\
\log \text { Precision }\end{array}$ & $\begin{array}{c}(4) \\
\log \text { Timeliness }\end{array}$ \\
\hline IDD & $\begin{array}{c}\mathbf{0 . 0 5 2 0} * * * * \\
(3.508)\end{array}$ & $\begin{array}{c}\text { 0.113**** } \\
(3.225)\end{array}$ & $\begin{array}{c}\mathbf{0 . 0 0 4 3 7} \\
(\mathbf{0 . 3 7 6})\end{array}$ & $\begin{array}{l}0.00532 \\
(0.253)\end{array}$ \\
\hline Size & $\begin{array}{c}-0.0859 * * * \\
(-7.742)\end{array}$ & $\begin{array}{c}-0.141 * * * \\
(-5.405)\end{array}$ & $\begin{array}{c}0.0612^{* * * *} \\
(7.778)\end{array}$ & $\begin{array}{c}0.0873 * * * \\
(5.765)\end{array}$ \\
\hline Size-Squared & $\begin{array}{c}0.0155^{* * * *} \\
(11.35)\end{array}$ & $\begin{array}{c}0.0305^{* * * *} \\
(9.715)\end{array}$ & $\begin{array}{l}0.00108 \\
(1.109)\end{array}$ & $\begin{array}{l}0.00207 \\
(1.106)\end{array}$ \\
\hline Age & $\begin{array}{l}0.00894^{* * * *} \\
\quad(11.07)\end{array}$ & $\begin{array}{c}0.0358^{* * * *} \\
(15.83)\end{array}$ & $\begin{array}{c}-0.0151 * * * \\
(-22.93)\end{array}$ & $\begin{array}{c}-0.0218 * * * \\
(-17.67)\end{array}$ \\
\hline Leverage & $\begin{array}{c}-0.0592^{* * * *} \\
(-3.820)\end{array}$ & $\begin{array}{c}-0.130^{* * * *} \\
(-3.392)\end{array}$ & $\begin{array}{c}-0.0572 * * * \\
(-4.136)\end{array}$ & $\begin{array}{c}-0.0894 * * * \\
(-3.480)\end{array}$ \\
\hline InstOwn & $\begin{array}{c}0.177 * * * \\
(7.739)\end{array}$ & $\begin{array}{c}0.417 * * * \\
(7.500)\end{array}$ & $\begin{array}{c}0.104 * * * \\
(5.371)\end{array}$ & $\begin{array}{c}0.177 * * * \\
(5.023)\end{array}$ \\
\hline \#Analyst & $\begin{array}{l}0.00779^{* * * *} \\
(5.698)\end{array}$ & $\begin{array}{c}0.0218 * * * * \\
(6.782)\end{array}$ & $\begin{array}{l}0.0112 * * * \\
(9.831)\end{array}$ & $\begin{array}{c}0.0191 * * * \\
(8.995)\end{array}$ \\
\hline Loss & $\begin{array}{c}-0.0473 * * * \\
(-8.638)\end{array}$ & $\begin{array}{c}-0.0933^{* * *} \\
(-6.217)\end{array}$ & $\begin{array}{c}-0.0357 * * * \\
(-5.761)\end{array}$ & $\begin{array}{c}-0.0291 * * \\
(-2.341)\end{array}$ \\
\hline Equity & $\begin{array}{c}-0.00333 \\
(-0.587)\end{array}$ & $\begin{array}{l}-0.0130 \\
(-0.928)\end{array}$ & $\begin{array}{c}-0.00752 \\
(-1.492)\end{array}$ & $\begin{array}{r}-0.00777 \\
(-0.817)\end{array}$ \\
\hline EarnVol & $\begin{array}{c}-0.0118^{* *} \\
(-2.343)\end{array}$ & $\begin{array}{c}-0.0351 * * * \\
(-2.636)\end{array}$ & $\begin{array}{c}-0.00593 \\
(-0.966)\end{array}$ & $\begin{array}{l}-0.0108 \\
(-0.955)\end{array}$ \\
\hline HHI & $\begin{array}{c}-0.154 \\
(-1.553)\end{array}$ & $\begin{array}{l}-0.471^{*} \\
(-1.946)\end{array}$ & $\begin{array}{l}0.0439 \\
(0.550)\end{array}$ & $\begin{array}{l}-0.0758 \\
(-0.519)\end{array}$ \\
\hline HHI-Squared & $\begin{array}{c}0.180 \\
(1.448)\end{array}$ & $\begin{array}{c}0.497 \\
(1.636)\end{array}$ & $\begin{array}{c}-0.100 \\
(-1.062)\end{array}$ & $\begin{array}{l}0.00830 \\
(0.0489)\end{array}$ \\
\hline Observations & 95,427 & 95,427 & 95,427 & 95,427 \\
\hline Adjusted R-squared & 0.354 & 0.306 & 0.319 & 0.283 \\
\hline Firm \& Year FE & Yes & Yes & Yes & Yes \\
\hline
\end{tabular}


The table reports the OLS estimates for the effect of state adoption of Inevitable Disclosure Doctrine (IDD) on the precision and timeliness of quarterly and annual management earnings forecasts. logPrecision is the log of (one plus) firm-year average of precision for individual forecast, which equals 3 for point forecast, 2 for range, 1 for qualitative forecast. logTimeliness is the log of (one plus) firm-year average of timeliness for individual forecast, which equals the number of days between forecast announcement day and fiscal period end day. IDD equals one for all fiscal years greater than or equal to the IDD-adoption year for firms located in adopting states, and zero otherwise. The sample period ranges from 1994 to 2011. Test statistics (two-sided) based on robust standard errors clustered at the firm level are reported in parenthesis. Asterisks $* * *, * *$, and * indicate statistical significance at the $1 \%, 5 \%$, and $10 \%$ level respectively. See Appendix B for variable definitions. 
Table 4-A: Main Results - Earnings Guidance Frequency and Managerial Myopia

\begin{tabular}{|c|c|c|c|c|c|c|}
\hline \multirow[b]{2}{*}{ Variables } & \multicolumn{3}{|c|}{ 2SLS $2^{\text {nd }}$ Stage (Instrument is IDD) } & \multicolumn{3}{|c|}{ OLS Estimates } \\
\hline & $\begin{array}{c}(1) \\
S G A_{t}\end{array}$ & $\begin{array}{c}(2) \\
R \& D_{t}\end{array}$ & $\begin{array}{c}(3) \\
C A P E X_{t}\end{array}$ & $\begin{array}{c}(4) \\
S G A_{t}\end{array}$ & $\begin{array}{c}(5) \\
R \& D_{t}\end{array}$ & $\begin{array}{c}\text { (6) } \\
\text { CAPEX } \\
\text { C }\end{array}$ \\
\hline $\begin{array}{l}\text { \# of Annual } \\
\text { Forecasts }\end{array}$ & $\begin{array}{l}-0.097 * * \\
(-2.421)\end{array}$ & $\begin{array}{c}-0.032 * * \\
(-2.449)\end{array}$ & $\begin{array}{c}-0.024 * * \\
(-2.250)\end{array}$ & $\begin{array}{c}-0.003 * * * \\
(-4.103)\end{array}$ & $\begin{array}{l}\text { 0.000* } \\
(1.835)\end{array}$ & $\begin{array}{c}0.001 * * * * \\
(4.864)\end{array}$ \\
\hline Size & $\begin{array}{c}-0.25 * * * \\
(-16.91)\end{array}$ & $\begin{array}{c}-0.07 * * * \\
(-13.95)\end{array}$ & $\begin{array}{c}-0.01 * * \\
(-1.98)\end{array}$ & $\begin{array}{c}-0.22 * * * \\
(-29.61)\end{array}$ & $\begin{array}{c}-0.06 * * * \\
(-22.26)\end{array}$ & $\begin{array}{c}0.00 \\
(0.58)\end{array}$ \\
\hline Size-Squared & $\begin{array}{c}0.01 * * * \\
(6.70)\end{array}$ & $\begin{array}{c}0.00 * * * \\
(6.60)\end{array}$ & $\begin{array}{c}0.00 \\
(1.54)\end{array}$ & $\begin{array}{c}0.01 * * * \\
(14.54)\end{array}$ & $\begin{array}{c}0.00 * * * \\
(13.75)\end{array}$ & $\begin{array}{c}-0.00 * * * \\
(-3.59)\end{array}$ \\
\hline Age & $\begin{array}{c}0.01 * * * \\
(20.54)\end{array}$ & $\begin{array}{c}0.00 * * * \\
(11.88)\end{array}$ & $\begin{array}{r}-0.00 * * * \\
(-16.07)\end{array}$ & $\begin{array}{c}0.01 * * * \\
(22.30)\end{array}$ & $\begin{array}{c}0.00 * * * \\
(12.53)\end{array}$ & $\begin{array}{c}-0.00 * * * \\
(-19.39)\end{array}$ \\
\hline Leverage & $\begin{array}{c}0.09 * * * \\
(7.51)\end{array}$ & $\begin{array}{c}0.02 * * * \\
(5.04)\end{array}$ & $\begin{array}{l}-0.00 \\
(-1.51)\end{array}$ & $\begin{array}{c}0.10^{* * * *} \\
(11.70)\end{array}$ & $\begin{array}{c}0.03 * * * \\
(8.08)\end{array}$ & $\begin{array}{l}-0.00 \\
(-0.01)\end{array}$ \\
\hline InstOwn & $\begin{array}{c}0.05^{* *} \\
(2.16)\end{array}$ & $\begin{array}{l}0.02 * * \\
(2.39)\end{array}$ & $\begin{array}{c}0.01 * * \\
(2.09)\end{array}$ & $\begin{array}{c}-0.00 \\
(-0.34)\end{array}$ & $\begin{array}{c}0.00 \\
(0.32)\end{array}$ & $\begin{array}{c}-0.00 \\
(-0.60)\end{array}$ \\
\hline \#Analyst & $\begin{array}{c}0.00^{* * * *} \\
(3.90)\end{array}$ & $\begin{array}{c}0.00 * * * \\
(2.75)\end{array}$ & $\begin{array}{c}0.00 * * * \\
(4.47)\end{array}$ & $\begin{array}{c}0.00^{* * * *} \\
(6.52)\end{array}$ & $\begin{array}{l}0.00^{*} \\
(1.94)\end{array}$ & $\begin{array}{c}0.00 * * * \\
(8.70)\end{array}$ \\
\hline Loss & $\begin{array}{c}0.05 * * * \\
(7.57)\end{array}$ & $\begin{array}{c}0.02 * * * \\
(7.22)\end{array}$ & $\begin{array}{c}-0.00 \\
(-1.26)\end{array}$ & $\begin{array}{c}0.06 * * * \\
(16.78)\end{array}$ & $\begin{array}{c}0.02 * * * \\
(15.47)\end{array}$ & $\begin{array}{c}0.00 \\
(1.62)\end{array}$ \\
\hline Equity & $\begin{array}{c}-0.00^{* *} \\
(-1.98)\end{array}$ & $\begin{array}{c}0.00 * * * \\
(4.97)\end{array}$ & $\begin{array}{c}0.00 * * * \\
(7.61)\end{array}$ & $\begin{array}{c}-0.00 \\
(-1.46)\end{array}$ & $\begin{array}{c}0.00 * * * \\
(7.64)\end{array}$ & $\begin{array}{c}0.01 * * * \\
(11.20)\end{array}$ \\
\hline EarnVol & $\begin{array}{c}0.01 \\
(1.06)\end{array}$ & $\begin{array}{l}0.01 * * \\
(2.45)\end{array}$ & $\begin{array}{l}0.00 * * \\
(2.31)\end{array}$ & $\begin{array}{l}0.02 * \\
(1.66)\end{array}$ & $\begin{array}{c}0.01 * * * \\
(3.03)\end{array}$ & $\begin{array}{c}0.01 * * * \\
(3.54)\end{array}$ \\
\hline HHI & $\begin{array}{c}-0.22 * * * \\
(-4.53)\end{array}$ & $\begin{array}{c}-0.13 * * * \\
(-7.82)\end{array}$ & $\begin{array}{c}-0.05 * * * \\
(-4.39)\end{array}$ & $\begin{array}{c}-0.19 * * * \\
(-4.64)\end{array}$ & $\begin{array}{c}-0.12 * * * \\
(-8.56)\end{array}$ & $\begin{array}{c}-0.04 * * * \\
(-4.54)\end{array}$ \\
\hline HHI-Squared & $\begin{array}{l}0.12^{* *} \\
(2.35)\end{array}$ & $\begin{array}{c}0.09^{* * * *} \\
(5.50)\end{array}$ & $\begin{array}{c}0.05 * * * \\
(3.49)\end{array}$ & $\begin{array}{c}0.09 * * \\
(2.11)\end{array}$ & $\begin{array}{c}0.08^{* * *} \\
(6.06)\end{array}$ & $\begin{array}{c}0.04 * * * \\
(3.59)\end{array}$ \\
\hline Observations & 95,427 & 95,427 & 95,427 & 95,427 & 95,427 & 95,427 \\
\hline Adjusted R-sq & 0.129 & 0.078 & 0.08 & 0.735 & 0.750 & 0.541 \\
\hline Firm \& Year FE & Yes & Yes & Yes & Yes & Yes & Yes \\
\hline First-Stage F-Stat & 15.72 & 15.72 & 15.72 & N/A & N/A & N/A \\
\hline
\end{tabular}


Table 4-B: Main Results - Earnings Guidance Incidence and Managerial Myopia

\begin{tabular}{|c|c|c|c|}
\hline Variables & $\begin{array}{r}(1) \\
\mathrm{SGA}_{\mathrm{t}} \\
\end{array}$ & $\begin{array}{r}(2) \\
R \& D_{t} \\
\end{array}$ & $\begin{array}{c}(3) \\
\text { CAPEX }_{\mathrm{t}}\end{array}$ \\
\hline $\begin{array}{l}\text { Annual Forecast Incidence } \\
\text { (Instrumented) }\end{array}$ & $\begin{array}{l}-0.480 * * \\
(-2.340)\end{array}$ & $\begin{array}{l}-0.159 * * \\
(-2.352)\end{array}$ & $\begin{array}{l}-0.119 * * \\
(-2.204)\end{array}$ \\
\hline Size & $\begin{array}{c}-0.234 * * * \\
(-21.88)\end{array}$ & $\begin{array}{c}-0.0659 * * * \\
(-17.35)\end{array}$ & $\begin{array}{c}-0.00324 \\
(-1.559)\end{array}$ \\
\hline Size-Squared & $\begin{array}{c}0.0126 * * * \\
(7.684)\end{array}$ & $\begin{array}{c}0.00411 * * * \\
(7.490)\end{array}$ & $\begin{array}{c}0.000483 \\
(1.228)\end{array}$ \\
\hline Age & $\begin{array}{c}0.0104 * * * \\
(12.34)\end{array}$ & $\begin{array}{c}0.00234 * * * \\
(8.214)\end{array}$ & $\begin{array}{c}-0.00119 * * * \\
(-5.584)\end{array}$ \\
\hline Leverage & $\begin{array}{c}0.0883 * * * \\
(7.491)\end{array}$ & $\begin{array}{l}0.0211 * * * \\
\quad(5.034)\end{array}$ & $\begin{array}{l}-0.00418 \\
(-1.436)\end{array}$ \\
\hline InstOwn & $\begin{array}{c}0.0696^{* *} \\
(2.189)\end{array}$ & $\begin{array}{c}0.0247 * * \\
(2.345)\end{array}$ & $\begin{array}{c}0.0176^{* *} \\
(2.116)\end{array}$ \\
\hline \#Analyst & $\begin{array}{c}0.00557 * * * \\
(3.307)\end{array}$ & $\begin{array}{c}0.00144 * * * \\
(2.597)\end{array}$ & $\begin{array}{c}0.00162 * * * \\
(3.645)\end{array}$ \\
\hline Loss & $\begin{array}{c}0.0427 * * * \\
(4.846)\end{array}$ & $\begin{array}{c}0.0135^{* * * *} \\
(4.603)\end{array}$ & $\begin{array}{c}-0.00349 \\
(-1.560)\end{array}$ \\
\hline Equity & $\begin{array}{c}-0.00442 * \\
(-1.856)\end{array}$ & $\begin{array}{c}0.00380 * * * \\
(4.803)\end{array}$ & $\begin{array}{c}0.00469 * * * \\
(7.413)\end{array}$ \\
\hline EarnVol & $\begin{array}{c}0.00950 \\
(0.838)\end{array}$ & $\begin{array}{c}0.00964 * * \\
(2.216)\end{array}$ & $\begin{array}{c}0.00370 * \\
(1.883)\end{array}$ \\
\hline HHI & $\begin{array}{c}-0.224 * * * \\
(-4.438)\end{array}$ & $\begin{array}{c}-0.128 * * * \\
(-7.579)\end{array}$ & $\begin{array}{c}-0.0516 * * * \\
(-4.280)\end{array}$ \\
\hline HHI-Squared & $\begin{array}{l}0.125 * * \\
(2.258)\end{array}$ & $\begin{array}{l}0.0953 * * * \\
(5.234)\end{array}$ & $\begin{array}{l}0.0469 * * * \\
(3.345)\end{array}$ \\
\hline Observations & 95,427 & 95,427 & 95,427 \\
\hline Adjusted R-squared & 0.105 & 0.06 & 0.078 \\
\hline Firm \& Year FE & Yes & Yes & Yes \\
\hline AP F-Stat & 14.44 & 14.44 & 14.44 \\
\hline
\end{tabular}


Table 4-C: Main Results - Earnings Guidance and Myopia (Reduced Form)

\begin{tabular}{|c|c|c|c|}
\hline Variables & $\begin{array}{c}(1) \\
S G A_{t} \\
\end{array}$ & $\begin{array}{c}(2) \\
R \& D_{t} \\
\end{array}$ & $\begin{array}{c}(3) \\
C A P E X_{t}\end{array}$ \\
\hline$I D D$ & $\begin{array}{c}-0.0135 * * * \\
(-3.012)\end{array}$ & $\begin{array}{c}-0.00447 * * * \\
(-3.125)\end{array}$ & $\begin{array}{c}-0.00335 * * * \\
(-2.743)\end{array}$ \\
\hline Size & $\begin{array}{c}-0.232 * * * \\
(-29.36)\end{array}$ & $\begin{array}{c}-0.0651 * * * \\
(-22.17)\end{array}$ & $\begin{array}{c}0.000463 \\
(0.420)\end{array}$ \\
\hline Size-Squared & $\begin{array}{c}0.0102 * * * \\
(14.84)\end{array}$ & $\begin{array}{c}0.00326 * * * \\
(14.02)\end{array}$ & $\begin{array}{c}-0.000345 * * * \\
(-3.356)\end{array}$ \\
\hline Age & $\begin{array}{c}0.00905 * * * \\
(22.17)\end{array}$ & $\begin{array}{c}0.00189 * * * \\
(12.63)\end{array}$ & $\begin{array}{c}-0.00160 * * * \\
(-19.03)\end{array}$ \\
\hline Leverage & $\begin{array}{c}0.110 * * * \\
(11.80)\end{array}$ & $\begin{array}{c}0.0290 * * * \\
(8.265)\end{array}$ & $\begin{array}{l}4.96 \mathrm{e}-05 \\
(0.0252)\end{array}$ \\
\hline InstOwn & $\begin{array}{c}-0.00132 \\
(-0.263)\end{array}$ & $\begin{array}{c}0.000981 \\
(0.551)\end{array}$ & $\begin{array}{c}-0.000332 \\
(-0.248)\end{array}$ \\
\hline \#Analyst & $\begin{array}{c}0.00178 * * * \\
(6.047)\end{array}$ & $\begin{array}{c}0.000198 * * \\
(2.000)\end{array}$ & $\begin{array}{c}0.000684 * * * \\
(8.938)\end{array}$ \\
\hline Loss & $\begin{array}{c}0.0612 * * * \\
(16.40)\end{array}$ & $\begin{array}{c}0.0193 * * * \\
(14.78)\end{array}$ & $\begin{array}{c}0.00118 \\
(1.552)\end{array}$ \\
\hline Equity & $\begin{array}{c}-0.00210 \\
(-1.133)\end{array}$ & $\begin{array}{c}0.00465^{* * * *} \\
(7.667)\end{array}$ & $\begin{array}{c}0.00519 * * * \\
\quad(11.11)\end{array}$ \\
\hline EarnVol & $\begin{array}{c}0.0194^{*} \\
(1.889)\end{array}$ & $\begin{array}{c}0.0114 * * * \\
(2.878)\end{array}$ & $\begin{array}{c}0.00502 * * * \\
(3.307)\end{array}$ \\
\hline HHI & $\begin{array}{c}-0.195 * * * \\
(-4.474)\end{array}$ & $\begin{array}{c}-0.122 * * * \\
(-8.560)\end{array}$ & $\begin{array}{c}-0.0435 * * * \\
(-4.492)\end{array}$ \\
\hline HHI-Squared & $\begin{array}{c}0.0888 * \\
(1.927)\end{array}$ & $\begin{array}{c}0.0866 * * * \\
(5.997)\end{array}$ & $\begin{array}{c}0.0383 * * * \\
(3.544)\end{array}$ \\
\hline Observations & 95,427 & 95,427 & 95,427 \\
\hline Adj R-squared & 0.735 & 0.750 & 0.541 \\
\hline Firm \& Year FE & Yes & Yes & Yes \\
\hline
\end{tabular}


Panel A reports both the 2SLS and OLS estimates for the effect of annual earnings guidance frequency on firm investments. Columns (1) - (3) use IDD (Inevitable Disclosure Doctrine) as an instrument for annual earnings guidance (see Table 2 for the first-stage).

Panel B reports the 2SLS estimates for the effect of annual earnings guidance incidence on firm investments. Columns (1) - (3) use IDD as an instrument for annual earnings guidance (see Table 2 for first-stage).

Panel $C$ reports the reduced form (OLS) difference-in-differences estimates, where IDD proxies for an increase in annual earnings guidance.

IDD equals one for all fiscal years greater than or equal to the IDD-adoption year for firms located in adopting states, and zero otherwise. SGA, R\&D, and CAPEX are the selling, general, admin and advertising expenses, research and development expenditures and capital expenditures respectively, scaled by the book value of assets.

The sample period ranges from 1994 to 2011. Test statistics (two-sided) based on robust standard errors clustered at the firm level are reported in parenthesis. Asterisks ***, **, and * indicate statistical significance at the 1\%,5\%, and 10\% level respectively. See Appendix B for variable definitions. 
Table 5-A: Sensitivity to Clustering Choices - State Clustering

\begin{tabular}{|c|c|c|c|c|c|}
\hline \multirow[b]{2}{*}{ Variables } & \multicolumn{2}{|c|}{ Annual Forecasts } & \multicolumn{3}{|c|}{ Investments } \\
\hline & $\begin{array}{c}1) \\
\text { Number }\end{array}$ & $\begin{array}{c}(2) \\
\text { Indicator }\end{array}$ & $\begin{array}{c}(3) \\
S G A_{t}\end{array}$ & $\begin{array}{c}(4) \\
R \& D_{t}\end{array}$ & $\begin{array}{c}(5) \\
\text { CAPEX }\end{array}$ \\
\hline IDD & $\begin{array}{c}0.140 * * * \\
(2.855)\end{array}$ & $\begin{array}{c}0.0282 * * * \\
(4.207)\end{array}$ & $\begin{array}{c}-0.0135 * * \\
(-2.164)\end{array}$ & $\begin{array}{c}-0.00447 * * * * \\
(-2.748)\end{array}$ & $\begin{array}{c}-0.00335^{*} \\
(-1.894)\end{array}$ \\
\hline Size & $\begin{array}{c}-0.290 * * * * \\
(-4.384)\end{array}$ & $\begin{array}{c}-0.0307 * * \\
(-2.416)\end{array}$ & $\begin{array}{c}-0.219 * * * \\
(-15.39)\end{array}$ & $\begin{array}{c}-0.0611 * * * \\
(-6.116)\end{array}$ & $\begin{array}{c}0.000404 \\
(0.332)\end{array}$ \\
\hline Size-Squared & $\begin{array}{c}0.0470 * * * * \\
(5.428)\end{array}$ & $\begin{array}{c}0.00689 * * * \\
(4.224)\end{array}$ & $\begin{array}{c}0.00934^{* * *} \\
(11.67)\end{array}$ & $\begin{array}{c}0.00302 * * * \\
\quad(6.971)\end{array}$ & $\begin{array}{c}-0.000336^{* * * *} \\
(-4.056)\end{array}$ \\
\hline Age & $\begin{array}{c}0.00151 \\
(0.554)\end{array}$ & $\begin{array}{c}0.00337 * * * \\
\quad(4.711)\end{array}$ & $\begin{array}{c}0.00876^{* * *} \\
(10.24)\end{array}$ & $\begin{array}{l}0.00180^{* * * *} \\
\quad(5.208)\end{array}$ & $\begin{array}{c}-0.00159^{* * *} \\
(-12.56)\end{array}$ \\
\hline Leverage & $\begin{array}{c}-0.179 * * * * \\
(-4.850)\end{array}$ & $\begin{array}{c}-0.0344 * * * \\
(-4.301)\end{array}$ & $\begin{array}{c}0.105^{* * * *} \\
(7.354)\end{array}$ & $\begin{array}{c}0.0266^{* * * *} \\
(3.462)\end{array}$ & $\begin{array}{r}-9.94 \mathrm{e}-05 \\
(-0.0351)\end{array}$ \\
\hline InstOwn & $\begin{array}{c}0.502 * * * \\
(7.546)\end{array}$ & $\begin{array}{c}0.151 * * * \\
(11.16)\end{array}$ & $\begin{array}{c}-0.00272 \\
(-0.393)\end{array}$ & $\begin{array}{c}0.000828 \\
(0.415)\end{array}$ & $\begin{array}{c}-0.000286 \\
(-0.185)\end{array}$ \\
\hline \#Analyst & $\begin{array}{c}0.0235 * * * \\
(4.514)\end{array}$ & $\begin{array}{c}0.00789 * * * \\
(6.086)\end{array}$ & $\begin{array}{c}0.00178^{* * *} * \\
(5.056)\end{array}$ & $\begin{array}{c}0.000188 \\
(1.338)\end{array}$ & $\begin{array}{c}0.000681 * * * \\
(6.557)\end{array}$ \\
\hline Loss & $\begin{array}{c}-0.129 * * * \\
(-8.320)\end{array}$ & $\begin{array}{c}-0.0385 * * * \\
(-9.898)\end{array}$ & $\begin{array}{c}0.0612 * * * \\
(12.81)\end{array}$ & $\begin{array}{c}0.0196 * * * \\
(5.527)\end{array}$ & $\begin{array}{l}0.00108 \\
(1.135)\end{array}$ \\
\hline Equity & $\begin{array}{l}-0.0203 \\
(-1.592)\end{array}$ & $\begin{array}{c}-0.00389 \\
(-1.037)\end{array}$ & $\begin{array}{c}-0.00255 \\
(-1.095)\end{array}$ & $\begin{array}{c}0.00441 * * * \\
\quad(4.378)\end{array}$ & $\begin{array}{c}0.00515^{* * * *} \\
(8.140)\end{array}$ \\
\hline EarnVol & $\begin{array}{c}-0.0641^{* * * *} \\
(-3.721)\end{array}$ & $\begin{array}{c}-0.0174 * * * \\
(-3.405)\end{array}$ & $\begin{array}{c}0.0179 * * \\
(2.265)\end{array}$ & $\begin{array}{c}0.0124 * * \\
(2.658)\end{array}$ & $\begin{array}{c}0.00576^{* *} \\
(2.586)\end{array}$ \\
\hline HHI & $\begin{array}{c}-0.284 \\
(-0.770)\end{array}$ & $\begin{array}{l}-0.0702 \\
(-0.815)\end{array}$ & $\begin{array}{c}-0.191 * * * \\
(-3.206)\end{array}$ & $\begin{array}{c}-0.117 * * * \\
(-4.922)\end{array}$ & $\begin{array}{c}-0.0432 * * * \\
(-3.189)\end{array}$ \\
\hline HHI-Squared & $\begin{array}{c}0.341 \\
(0.836)\end{array}$ & $\begin{array}{l}0.0739 \\
(0.756)\end{array}$ & $\begin{array}{l}0.0898 \\
(1.475)\end{array}$ & $\begin{array}{c}0.0835^{* * * *} \\
(4.767)\end{array}$ & $\begin{array}{c}0.0381 * * \\
(2.436)\end{array}$ \\
\hline Observations & 95,427 & 95,427 & 95,427 & 95,427 & 95,427 \\
\hline Adjusted R-squared & 0.475 & 0.440 & 0.745 & 0.761 & 0.542 \\
\hline Firm \& Year FE & Yes & Yes & Yes & Yes & Yes \\
\hline Clustering & State & State & State & State & State \\
\hline
\end{tabular}


Table 5-B: Sensitivity to Clustering Choices - State-Year Clustering

\begin{tabular}{|c|c|c|c|c|c|}
\hline \multirow[b]{2}{*}{ Variables } & \multicolumn{2}{|c|}{ Annual Forecasts } & \multicolumn{3}{|c|}{ Investments } \\
\hline & $\begin{array}{c}\text { (1) } \\
\text { Number }\end{array}$ & $\begin{array}{c}(2) \\
\text { Indicator }\end{array}$ & $\begin{array}{c}3)_{t} \\
S G A_{t}\end{array}$ & $\begin{array}{c}(4) \\
R \& D_{t}\end{array}$ & $\begin{array}{c}5) \\
\text { CAPEX }\end{array}$ \\
\hline IDD & $\begin{array}{c}0.140 * * * \\
(5.888)\end{array}$ & $\begin{array}{c}0.0282 * * * \\
(5.416)\end{array}$ & $\begin{array}{c}-0.0135 * * * \\
(-4.213)\end{array}$ & $\begin{array}{c}-0.00447 * * * \\
(-4.537)\end{array}$ & $\begin{array}{c}-\mathbf{0 . 0 0 3 3 5} * * * \\
(-2.838)\end{array}$ \\
\hline Size & $\begin{array}{c}-0.290 * * * \\
(-12.41)\end{array}$ & $\begin{array}{c}-0.0307 * * * \\
(-6.444)\end{array}$ & $\begin{array}{c}-0.219 * * * \\
(-32.41)\end{array}$ & $\begin{array}{c}-0.0611 * * * \\
(-17.24)\end{array}$ & $\begin{array}{c}0.000404 \\
(0.422)\end{array}$ \\
\hline Size-Squared & $\begin{array}{c}0.0470^{* * *} \\
(15.53)\end{array}$ & $\begin{array}{c}0.00689^{* * *} \\
(11.48)\end{array}$ & $\begin{array}{c}0.00934 * * * \\
(20.13)\end{array}$ & $\begin{array}{c}0.00302^{* * *} \\
(14.99)\end{array}$ & $\begin{array}{c}-0.000336 * * * \\
(-4.577)\end{array}$ \\
\hline Age & $\begin{array}{l}0.00151 \\
(0.759)\end{array}$ & $\begin{array}{c}0.00337 * * * \\
(6.451)\end{array}$ & $\begin{array}{c}0.00876^{* * * *} \\
(23.11)\end{array}$ & $\begin{array}{c}0.00180^{* * * *} \\
(13.76)\end{array}$ & $\begin{array}{c}-0.00159^{* * * *} \\
(-16.36)\end{array}$ \\
\hline Leverage & $\begin{array}{c}-0.179 * * * \\
(-7.699)\end{array}$ & $\begin{array}{c}-0.0344 * * * \\
(-5.771)\end{array}$ & $\begin{array}{c}0.105 * * * \\
(13.97)\end{array}$ & $\begin{array}{c}0.0266^{* * *} * \\
(8.528)\end{array}$ & $\begin{array}{r}-9.94 \mathrm{e}-05 \\
(-0.0590)\end{array}$ \\
\hline InstOwn & $\begin{array}{c}0.502 * * * \\
(12.58)\end{array}$ & $\begin{array}{c}0.151^{* * *} \\
(16.29)\end{array}$ & $\begin{array}{c}-0.00272 \\
(-0.808)\end{array}$ & $\begin{array}{c}0.000828 \\
(0.684)\end{array}$ & $\begin{array}{c}-0.000286 \\
(-0.279)\end{array}$ \\
\hline \#Analyst & $\begin{array}{c}0.0235^{* * *} * \\
(9.930)\end{array}$ & $\begin{array}{c}0.00789^{* * * *} \\
(14.38)\end{array}$ & $\begin{array}{c}0.00178 * * * \\
(9.526)\end{array}$ & $\begin{array}{c}0.000188^{* * *} \\
(2.302)\end{array}$ & $\begin{array}{c}0.000681^{* * * *} \\
(11.56)\end{array}$ \\
\hline Loss & $\begin{array}{c}-0.129^{* * * *} \\
(-11.18)\end{array}$ & $\begin{array}{c}-0.0385^{* * * *} \\
(-11.70)\end{array}$ & $\begin{array}{c}0.0612 * * * \\
(19.52)\end{array}$ & $\begin{array}{c}0.0196^{* * * *} \\
(14.85)\end{array}$ & $\begin{array}{l}0.00108 \\
(1.505)\end{array}$ \\
\hline Equity & $\begin{array}{c}-0.0203^{* *} \\
(-1.977)\end{array}$ & $\begin{array}{c}-0.00389 \\
(-1.576)\end{array}$ & $\begin{array}{c}-0.00255 \\
(-1.645)\end{array}$ & $\begin{array}{c}0.00441 * * * \\
(8.292)\end{array}$ & $\begin{array}{c}0.00515 * * * \\
(12.47)\end{array}$ \\
\hline EarnVol & $\begin{array}{c}-0.0641 * * * \\
(-5.929)\end{array}$ & $\begin{array}{c}-0.0174 * * * \\
(-5.921)\end{array}$ & $\begin{array}{c}0.0179^{* *} \\
(2.208)\end{array}$ & $\begin{array}{c}0.0124 * * * \\
(4.032)\end{array}$ & $\begin{array}{c}0.00576^{* * * *} \\
(4.459)\end{array}$ \\
\hline HHI & $\begin{array}{l}-0.284^{*} \\
(-1.930)\end{array}$ & $\begin{array}{c}-0.0702 * \\
(-1.942)\end{array}$ & $\begin{array}{c}-0.191 * * * \\
(-5.735)\end{array}$ & $\begin{array}{c}-0.117 * * * \\
(-10.74)\end{array}$ & $\begin{array}{c}-0.0432 * * * * \\
(-5.295)\end{array}$ \\
\hline HHI-Squared & $\begin{array}{l}0.341 * \\
(1.936)\end{array}$ & $\begin{array}{l}0.0739^{*} \\
(1.671)\end{array}$ & $\begin{array}{c}0.0898^{* *} \\
(2.437)\end{array}$ & $\begin{array}{c}0.0835 * * * \\
(7.733)\end{array}$ & $\begin{array}{c}0.0381 * * * \\
(4.085)\end{array}$ \\
\hline Observations & 95,427 & 95,427 & 95,427 & 95,427 & 95,427 \\
\hline Adjusted R-squared & 0.475 & 0.440 & 0.745 & 0.761 & 0.542 \\
\hline Firm and Year FE & Yes & Yes & Yes & Yes & Yes \\
\hline Clustering & State-Year & State-Year & State-Year & State-Year & State-Year \\
\hline
\end{tabular}


Table 5-C: Sensitivity to Clustering Choices - Firm and State-Year Clustering

\begin{tabular}{|c|c|c|c|c|c|}
\hline \multirow[b]{3}{*}{ Variables } & \multicolumn{2}{|c|}{ Annual Forecasts } & \multicolumn{3}{|c|}{ Investments } \\
\hline & (1) & (2) & (3) & (4) & (5) \\
\hline & Number & Indicator & $S G A_{t}$ & $R \& D_{t}$ & $C A P E X_{t}$ \\
\hline IDD & $\begin{array}{c}0.140 * * * \\
(3.514)\end{array}$ & $\begin{array}{c}\mathbf{0 . 0 2 8 2} * * * \\
(\mathbf{3 . 3 5 4})\end{array}$ & $\begin{array}{c}-0.0135 * * * \\
(-2.932)\end{array}$ & $\begin{array}{c}-0.00447 * * * \\
(-3.101)\end{array}$ & $\begin{array}{c}-0.00335 * * \\
(-2.324)\end{array}$ \\
\hline Size & $\begin{array}{c}-0.290 * * * \\
(-8.223)\end{array}$ & $\begin{array}{c}-0.0307 * * * \\
(-4.396)\end{array}$ & $\begin{array}{c}-0.219 * * * \\
(-24.92)\end{array}$ & $\begin{array}{c}-0.0611 * * * \\
(-15.23)\end{array}$ & $\begin{array}{c}0.000404 \\
(0.330)\end{array}$ \\
\hline Size-Squared & $\begin{array}{l}0.0470 * * * \\
(10.60)\end{array}$ & $\begin{array}{c}0.00689 * * * \\
(7.996)\end{array}$ & $\begin{array}{c}0.00934 * * * \\
(13.21)\end{array}$ & $\begin{array}{c}0.00302 * * * \\
(11.48)\end{array}$ & $\begin{array}{c}-0.000336 * * * \\
(-3.172)\end{array}$ \\
\hline Age & $\begin{array}{l}0.00151 \\
(0.678)\end{array}$ & $\begin{array}{c}0.00337 * * * \\
(5.987)\end{array}$ & $\begin{array}{c}0.00876^{* * * *} \\
(19.27)\end{array}$ & $\begin{array}{c}0.00180 * * * \\
(11.43)\end{array}$ & $\begin{array}{c}-0.00159 * * * \\
(-15.15)\end{array}$ \\
\hline Leverage & $\begin{array}{c}-0.179 * * * \\
(-4.634)\end{array}$ & $\begin{array}{c}-0.0344 * * * \\
(-3.903)\end{array}$ & $\begin{array}{c}0.105 * * * \\
(11.01)\end{array}$ & $\begin{array}{c}0.0266 * * * \\
(7.146)\end{array}$ & $\begin{array}{l}-9.94 \mathrm{e}-05 \\
(-0.0484)\end{array}$ \\
\hline InstOwn & $\begin{array}{c}0.502 * * * \\
(9.064)\end{array}$ & $\begin{array}{c}0.151 * * * \\
(11.95)\end{array}$ & $\begin{array}{c}-0.00272 \\
(-0.543)\end{array}$ & $\begin{array}{c}0.000828 \\
(0.489)\end{array}$ & $\begin{array}{c}-0.000286 \\
(-0.211)\end{array}$ \\
\hline \#Analyst & $\begin{array}{c}0.0235^{* * * *} \\
(6.304)\end{array}$ & $\begin{array}{c}0.00789 * * * \\
(9.833)\end{array}$ & $\begin{array}{c}0.00178 * * * \\
(5.920)\end{array}$ & $\begin{array}{c}0.000188 * \\
(1.747)\end{array}$ & $\begin{array}{c}0.000681 * * * \\
(8.559)\end{array}$ \\
\hline Loss & $\begin{array}{c}-0.129 * * * \\
(-9.055)\end{array}$ & $\begin{array}{c}-0.0385^{* * * *} \\
(-10.22)\end{array}$ & $\begin{array}{c}0.0612 * * * \\
(15.50)\end{array}$ & $\begin{array}{l}0.0196 * * * \\
(12.76)\end{array}$ & $\begin{array}{l}0.00108 \\
(1.335)\end{array}$ \\
\hline Equity & $\begin{array}{l}-0.0203 \\
(-1.501)\end{array}$ & $\begin{array}{c}-0.00389 \\
(-1.282)\end{array}$ & $\begin{array}{l}-0.00255 \\
(-1.380)\end{array}$ & $\begin{array}{c}0.00441 * * * \\
(7.125)\end{array}$ & $\begin{array}{l}0.00515^{* * * *} \\
(10.79)\end{array}$ \\
\hline EarnVol & $\begin{array}{c}-0.0641 * * * \\
(-3.880)\end{array}$ & $\begin{array}{c}-0.0174 * * * \\
(-4.127)\end{array}$ & $\begin{array}{l}0.0179 * \\
(1.681)\end{array}$ & $\begin{array}{c}0.0124 * * * \\
(3.004)\end{array}$ & $\begin{array}{c}0.00576 * * * \\
(3.452)\end{array}$ \\
\hline HHI & $\begin{array}{l}-0.284 \\
(-1.183)\end{array}$ & $\begin{array}{l}-0.0702 \\
(-1.278)\end{array}$ & $\begin{array}{c}-0.191 * * * \\
(-4.206)\end{array}$ & $\begin{array}{c}-0.117 * * * \\
(-7.788)\end{array}$ & $\begin{array}{c}-0.0432 * * * \\
(-4.169)\end{array}$ \\
\hline HHI-Squared & $\begin{array}{c}0.341 \\
(1.193)\end{array}$ & $\begin{array}{l}0.0739 \\
(1.097)\end{array}$ & $\begin{array}{c}0.0898 * \\
(1.862)\end{array}$ & $\begin{array}{c}0.0835 * * * \\
(5.635)\end{array}$ & $\begin{array}{c}0.0381 * * * \\
(3.277)\end{array}$ \\
\hline Observations & 95,427 & 95,427 & 95,427 & 95,427 & 95,427 \\
\hline Adjusted R-squared & 0.440 & 0.475 & 0.745 & 0.761 & 0.542 \\
\hline Firm and Year FE & Yes & Yes & Yes & Yes & Yes \\
\hline $\begin{array}{l}\text { Clustering } \\
\text { (Two-way) }\end{array}$ & $\begin{array}{c}\text { Firm \& } \\
\text { State-Year }\end{array}$ & $\begin{array}{c}\text { Firm \& } \\
\text { State-Year }\end{array}$ & $\begin{array}{c}\text { Firm \& } \\
\text { State-Year }\end{array}$ & $\begin{array}{c}\text { Firm \& } \\
\text { State-Year }\end{array}$ & $\begin{array}{c}\text { Firm \& } \\
\text { State-Year }\end{array}$ \\
\hline
\end{tabular}


The table tests the sensitivity of main results to clustering choices. Test statistics (two-sided) based on robust standard errors clustered at the state level (Panel A), State-Year level (Panel B) and Firm plus State-Year level (Panel C) are reported in parenthesis.

IDD equals one for all fiscal years greater than or equal to the IDD-adoption year for firms located in adopting states, and zero otherwise. SGA, R\&D, and CAPEX are the selling, general, admin and advertising expenses, research and development expenditures and capital expenditures respectively, scaled by the book value of assets.

The sample period ranges from 1994 to 2011. Asterisks ***, **, and * indicate statistical significance at the 1\%, 5\%, and 10\% level respectively. See Appendix B for variable definitions. 
Table 6-A: Consequences of Myopia - Revenue Growth

\begin{tabular}{|c|c|c|c|}
\hline Variables & $\begin{array}{c}(1) \\
\text { RevGrowth }\end{array}$ & $\begin{array}{c}(2) \\
\text { RevGrowth } \\
\text { t+1 }\end{array}$ & $\begin{array}{c}(3) \\
\text { RevGrowth } \\
\end{array}$ \\
\hline IDD & $\begin{array}{c}0.01 \\
(1.336)\end{array}$ & $\begin{array}{c}-0.003 \\
(-0.431)\end{array}$ & $\begin{array}{l}-0.016 * * \\
(-2.278)\end{array}$ \\
\hline Size & $\begin{array}{c}0.0987 * * * \\
(9.652)\end{array}$ & $\begin{array}{c}-0.104 * * * \\
(-10.45)\end{array}$ & $\begin{array}{c}-0.156 * * * \\
(-15.29)\end{array}$ \\
\hline Size-Squared & $\begin{array}{c}-0.00244 * * * \\
(-2.862)\end{array}$ & $\begin{array}{c}0.00284 * * * \\
(3.454)\end{array}$ & $\begin{array}{c}0.00134 \\
(1.625)\end{array}$ \\
\hline Age & $\begin{array}{c}-0.0154 * * * \\
(-21.68)\end{array}$ & $\begin{array}{c}-0.00479 * * * \\
(-6.577)\end{array}$ & $\begin{array}{l}0.00175 * * \\
(2.282)\end{array}$ \\
\hline Leverage & $\begin{array}{c}-0.0288^{*} \\
(-1.710)\end{array}$ & $\begin{array}{c}-0.101 * * * \\
(-5.986)\end{array}$ & $\begin{array}{c}-0.0754 * * * \\
(-4.181)\end{array}$ \\
\hline InstOwn & $\begin{array}{l}-0.0135 \\
(-1.490)\end{array}$ & $\begin{array}{c}0.00970 \\
(1.053)\end{array}$ & $\begin{array}{c}0.0189 * * \\
(2.160)\end{array}$ \\
\hline \#Analyst & $\begin{array}{c}-0.00547 * * * \\
(-10.26)\end{array}$ & $\begin{array}{c}-0.00274 * * * \\
(-5.578)\end{array}$ & $\begin{array}{c}0.000890 * * \\
(2.017)\end{array}$ \\
\hline Loss & $\begin{array}{c}-0.194 * * * \\
(-26.11)\end{array}$ & $\begin{array}{c}0.0571 * * * \\
(7.560)\end{array}$ & $\begin{array}{c}0.0373 * * * \\
(5.151)\end{array}$ \\
\hline Equity & $\begin{array}{c}0.0867 * * * \\
(23.54)\end{array}$ & $\begin{array}{c}0.0477 * * * \\
(12.87)\end{array}$ & $\begin{array}{c}0.00725^{*} \\
(1.948)\end{array}$ \\
\hline EarnVol & $\begin{array}{c}0.233 * * * \\
(12.48)\end{array}$ & $\begin{array}{c}0.111 * * * \\
(6.103)\end{array}$ & $\begin{array}{c}0.0684 * * * \\
(3.479)\end{array}$ \\
\hline HHI & $\begin{array}{l}-0.187 * * \\
(-2.441)\end{array}$ & $\begin{array}{l}-0.140 * \\
(-1.759)\end{array}$ & $\begin{array}{l}-0.0699 \\
(-0.891)\end{array}$ \\
\hline HHI-Squared & $\begin{array}{l}0.0638 \\
(0.723)\end{array}$ & $\begin{array}{c}0.289 * * * \\
(3.251)\end{array}$ & $\begin{array}{c}0.145 \\
(1.629)\end{array}$ \\
\hline Observations & 93,505 & 82,410 & 71,933 \\
\hline Adjusted R-squared & 0.197 & 0.155 & 0.150 \\
\hline Firm FE & Yes & Yes & Yes \\
\hline Year FE & Yes & Yes & Yes \\
\hline
\end{tabular}


Table 6-B: Consequences of Myopia - Innovation as Measured by Patents

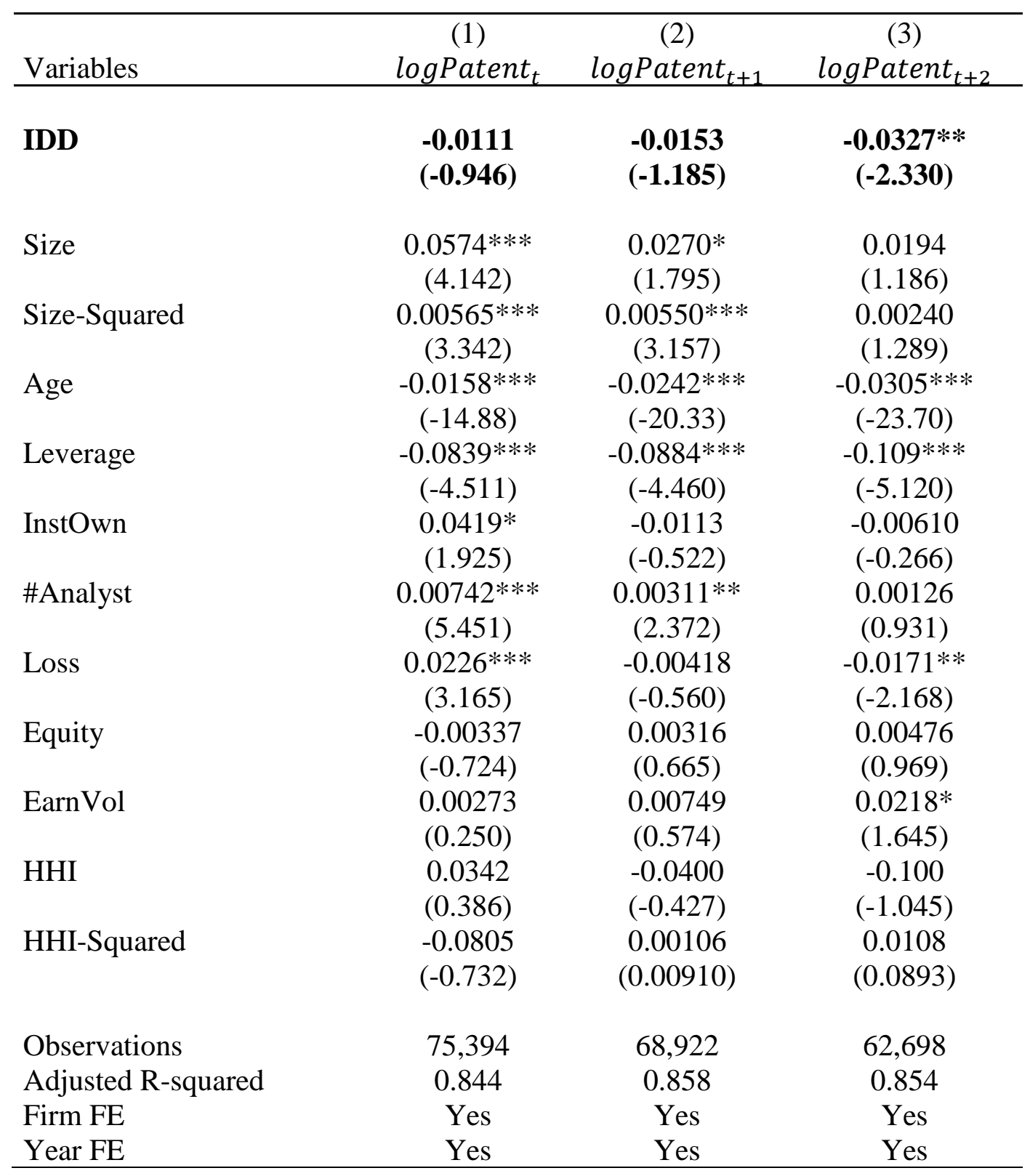


Table 6-C: Consequences of Myopia - Innovation as Measured by Citations

\begin{tabular}{|c|c|c|c|}
\hline Variables & $\begin{array}{c}(1) \\
\operatorname{logCite}{ }_{t}\end{array}$ & $\begin{array}{c}(2) \\
\log \text { Cite }_{t+1}\end{array}$ & $\begin{array}{c}(3) \\
\log \text { Cite }_{t+2}\end{array}$ \\
\hline IDD & $\begin{array}{l}-0.0281 \\
(-1.155)\end{array}$ & $\begin{array}{l}-0.0447 \\
(-1.575)\end{array}$ & $\begin{array}{c}-0.0718 * * \\
(-2.289)\end{array}$ \\
\hline Size & $\begin{array}{c}0.197 * * * \\
(8.030)\end{array}$ & $\begin{array}{c}0.105^{* * * *} \\
(3.566)\end{array}$ & $\begin{array}{c}0.0965 * * * \\
(2.896)\end{array}$ \\
\hline Size-Squared & $\begin{array}{c}-0.00417 \\
(-1.470)\end{array}$ & $\begin{array}{c}-0.00420 \\
(-1.243)\end{array}$ & $\begin{array}{c}-0.0103 * * * \\
(-2.666)\end{array}$ \\
\hline Age & $\begin{array}{c}-0.0709 * * * \\
(-29.85)\end{array}$ & $\begin{array}{c}-0.0820 * * * \\
(-30.30)\end{array}$ & $\begin{array}{c}-0.0824 * * * \\
(-28.32)\end{array}$ \\
\hline Leverage & $\begin{array}{c}-0.274 * * * \\
(-7.202)\end{array}$ & $\begin{array}{c}-0.244 * * * \\
(-5.974)\end{array}$ & $\begin{array}{c}-0.274 * * * \\
(-6.282)\end{array}$ \\
\hline InstOwn & $\begin{array}{l}0.0262 \\
(0.613)\end{array}$ & $\begin{array}{l}-0.110 * * \\
(-2.416)\end{array}$ & $\begin{array}{l}-0.121 * * \\
(-2.435)\end{array}$ \\
\hline \#Analyst & $\begin{array}{c}0.00799 * * * \\
(3.260)\end{array}$ & $\begin{array}{c}-0.000766 \\
(-0.292)\end{array}$ & $\begin{array}{c}-0.00345 \\
(-1.165)\end{array}$ \\
\hline Loss & $\begin{array}{c}0.0327 * * \\
(2.087)\end{array}$ & $\begin{array}{l}-0.0134 \\
(-0.793)\end{array}$ & $\begin{array}{c}-0.0564 * * * \\
(-3.269)\end{array}$ \\
\hline Equity & $\begin{array}{l}0.0158^{*} \\
(1.656)\end{array}$ & $\begin{array}{c}0.0309 * * * \\
(3.091)\end{array}$ & $\begin{array}{c}0.0350 * * * \\
(3.243)\end{array}$ \\
\hline EarnVol & $\begin{array}{c}0.0736 * * * \\
(2.801)\end{array}$ & $\begin{array}{c}0.0890 * * * \\
(2.988)\end{array}$ & $\begin{array}{c}0.113 * * * \\
(3.640)\end{array}$ \\
\hline $\mathrm{HHI}$ & $\begin{array}{c}0.283 \\
(1.588)\end{array}$ & $\begin{array}{c}0.192 \\
(0.960)\end{array}$ & $\begin{array}{c}0.105 \\
(0.491)\end{array}$ \\
\hline HHI-Squared & $\begin{array}{l}-0.410 * \\
(-1.922)\end{array}$ & $\begin{array}{c}-0.301 \\
(-1.259)\end{array}$ & $\begin{array}{c}-0.286 \\
(-1.109)\end{array}$ \\
\hline Observations & 75,394 & 68,922 & 62,698 \\
\hline Adjusted R-squared & 0.748 & 0.751 & 0.737 \\
\hline Firm FE & Yes & Yes & Yes \\
\hline Year FE & Yes & Yes & Yes \\
\hline
\end{tabular}


Table 6-D: Consequences of Myopia - Evolution of Stock Returns

\begin{tabular}{|c|c|c|c|}
\hline Variables & $\begin{array}{c}\text { (1) } \\
\text { Return }_{t}\end{array}$ & $\begin{array}{c}(2) \\
\text { Return }_{t+1} \\
\end{array}$ & $\begin{array}{c}\text { (3) } \\
\text { Return }_{t+2}\end{array}$ \\
\hline IDD & $\begin{array}{l}-0.0168 \\
(-1.139)\end{array}$ & $\begin{array}{c}-0.0503 * * * \\
(-2.608)\end{array}$ & $\begin{array}{c}-0.0336 * \\
(-1.878)\end{array}$ \\
\hline Size & $\begin{array}{c}0.0841 * * * \\
(3.647)\end{array}$ & $\begin{array}{c}-0.548 * * * \\
(-18.72)\end{array}$ & $\begin{array}{c}-0.289 * * * \\
(-10.46)\end{array}$ \\
\hline Size-Squared & $\begin{array}{c}-0.0101 * * * \\
(-5.365)\end{array}$ & $\begin{array}{c}0.0125 * * * \\
(4.912)\end{array}$ & $\begin{array}{c}0.00445^{*} \\
(1.899)\end{array}$ \\
\hline Age & $\begin{array}{c}0.0101 * * * \\
(8.975)\end{array}$ & $\begin{array}{c}-0.00767 \\
(-1.061)\end{array}$ & $\begin{array}{c}-0.00321 \\
(-0.637)\end{array}$ \\
\hline Leverage & $\begin{array}{c}-0.177 * * * \\
(-4.993)\end{array}$ & $\begin{array}{c}0.374 * * * \\
(7.839)\end{array}$ & $\begin{array}{c}0.312 * * * \\
(6.036)\end{array}$ \\
\hline InstOwn & $\begin{array}{c}-0.00529 \\
(-0.262)\end{array}$ & $\begin{array}{c}-0.0671 * * * \\
(-3.138)\end{array}$ & $\begin{array}{l}-0.0306 \\
(-1.064)\end{array}$ \\
\hline \#Analyst & $\begin{array}{c}-0.0175 * * * \\
(-13.64)\end{array}$ & $\begin{array}{c}-0.00623 * * * \\
(-4.873)\end{array}$ & $\begin{array}{c}-0.00233 * \\
(-1.873)\end{array}$ \\
\hline Loss & $\begin{array}{c}-0.312 * * * \\
(-14.89)\end{array}$ & $\begin{array}{l}0.0364 \\
(1.480)\end{array}$ & $\begin{array}{c}0.0882 * * * \\
(3.178)\end{array}$ \\
\hline Equity & $\begin{array}{c}0.0539 * * * \\
(6.084)\end{array}$ & $\begin{array}{c}-0.0423 * * * \\
(-4.162)\end{array}$ & $\begin{array}{c}-0.0218 * * \\
(-2.185)\end{array}$ \\
\hline EarnVol & $\begin{array}{c}-0.146 * * * \\
(-4.050)\end{array}$ & $\begin{array}{l}0.0594^{*} \\
(1.648)\end{array}$ & $\begin{array}{c}0.0596^{*} \\
(1.796)\end{array}$ \\
\hline HHI & $\begin{array}{c}0.655^{* *} * \\
(2.051)\end{array}$ & $\begin{array}{c}0.327 \\
(0.856)\end{array}$ & $\begin{array}{l}-0.311 \\
(-0.622)\end{array}$ \\
\hline HHI-Squared & $\begin{array}{c}-0.588 * * \\
(-2.139)\end{array}$ & $\begin{array}{c}-0.183 \\
(-0.569)\end{array}$ & $\begin{array}{c}0.350 \\
(0.755)\end{array}$ \\
\hline $\begin{array}{l}\text { Observations } \\
\text { Adjusted R-squared } \\
\text { Firm FE } \\
\text { Year FE }\end{array}$ & $\begin{array}{c}73,758 \\
0.167 \\
\text { Yes } \\
\text { Yes }\end{array}$ & $\begin{array}{c}64,304 \\
0.118 \\
\text { Yes } \\
\text { Yes }\end{array}$ & $\begin{array}{c}55,363 \\
0.089 \\
\text { Yes } \\
\text { Yes }\end{array}$ \\
\hline
\end{tabular}


The table reports the estimates for the effect of an increase in annual earnings guidance (as proxied by IDD) on firm revenue growth (Panel A), innovation as measured by patent (Panel B), innovation as measured by citations (Panel C), and stock returns (Panel D).

IDD (Inevitable Disclosure Doctrine) equals one for all fiscal years greater than or equal to the IDD-adoption year for firms located in adopting states, and zero otherwise. Revenue Growth is the year-on-year revenue growth. logPatent is the logarithm of (one plus) number of patents a firm receives in a fiscal year. log Cite is the logarithm of (one plus) number of citations a firm's patent receives in subsequent years. Return is the annual raw returns for the fiscal year.

The sample period ranges from 1994 to 2011 for Panels A and D and from 1994 to 2006 for Panels B and C. All specifications are estimated using the OLS regression. Test statistics (twosided) based on robust standard errors clustered at the firm level are reported in parenthesis. Asterisks $* * *, * *$, and $*$ indicate statistical significance at the $1 \%, 5 \%$, and $10 \%$ level respectively. See Appendix B for variable definitions 
Table 7-A: Cross-Sectional Variations in the Effect of IDD on Earnings Forecasts

\begin{tabular}{|c|c|c|c|c|c|}
\hline & & \# of $\mathrm{A}$ & hual Forecast & & \\
\hline & (1) & (2) & (3) & (4) & (5) \\
\hline XS Variables $\rightarrow$ & $\begin{array}{l}\text { Trade Secret } \\
\text { Intensity }\end{array}$ & Close Rivals & $\begin{array}{c}\text { Earnings } \\
\text { Uncertainty }\end{array}$ & ERC & CEO Tenure \\
\hline IDD $\times$ XS_Variable & $\begin{array}{c}0.323 * * * \\
(5.120)\end{array}$ & $\begin{array}{c}\mathbf{0 . 0 8 9 2} * * \\
(2.253)\end{array}$ & $\begin{array}{l}0.03 * * \\
(2.467)\end{array}$ & $\begin{array}{l}\text { 0.018** } \\
(2.171)\end{array}$ & $\begin{array}{c}-0.103 * * \\
(-2.352)\end{array}$ \\
\hline IDD & $\begin{array}{l}0.0401 \\
(1.146)\end{array}$ & $\begin{array}{c}0.103 * * \\
(2.387)\end{array}$ & $\begin{array}{c}0.118^{* * * *} \\
(7.993)\end{array}$ & $\begin{array}{c}0.107^{* * *} \\
(3.604)\end{array}$ & $\begin{array}{c}0.178^{* *} \\
(2.417)\end{array}$ \\
\hline XS_Vaiable & & $\begin{array}{c}-0.00543 \\
(-0.262)\end{array}$ & $\begin{array}{c}-0.037 * * * \\
(-3.567)\end{array}$ & $\begin{array}{c}-0.019 * * * \\
(-4.919)\end{array}$ & $\begin{array}{c}0.025 \\
(1.155)\end{array}$ \\
\hline SIZE & $\begin{array}{c}-0.228 * * * \\
(-9.647)\end{array}$ & $\begin{array}{c}-0.254 * * * \\
(-31.45)\end{array}$ & $\begin{array}{c}-0.224 * * * \\
(-19.033)\end{array}$ & $\begin{array}{c}-0.215^{* * * *} \\
(-8.884)\end{array}$ & $\begin{array}{l}-0.0392 \\
(-0.380)\end{array}$ \\
\hline SIZE2 & $\begin{array}{c}0.0355 * * * \\
(11.93)\end{array}$ & $\begin{array}{c}0.00920 * * * \\
(16.19)\end{array}$ & $\begin{array}{c}0.035^{* * * *} \\
(29.558)\end{array}$ & $\begin{array}{c}0.035^{* * *} \\
(11.516)\end{array}$ & $\begin{array}{c}0.0174 * * \\
(2.303)\end{array}$ \\
\hline AGE & $\begin{array}{c}0.0106^{* * * *} \\
(6.926)\end{array}$ & $\begin{array}{c}0.0101 * * * \\
(15.77)\end{array}$ & $\begin{array}{c}0.013^{* * * *} \\
(8.348)\end{array}$ & $\begin{array}{c}0.011^{* * * *} \\
(6.691)\end{array}$ & $\begin{array}{c}0.0511^{* * *} \\
(11.31)\end{array}$ \\
\hline LEVb & $\begin{array}{c}-0.141 * * * \\
(-4.571)\end{array}$ & $\begin{array}{c}0.0942 * * * \\
(10.84)\end{array}$ & $\begin{array}{c}-0.138 * * * \\
(-5.774)\end{array}$ & $\begin{array}{c}-0.130 * * * \\
(-4.038)\end{array}$ & $\begin{array}{c}-0.390^{* * * *} \\
(-3.104)\end{array}$ \\
\hline inst & $\begin{array}{c}0.396 * * * \\
(8.764)\end{array}$ & $\begin{array}{c}-0.0105 * * * \\
(-2.686)\end{array}$ & $\begin{array}{c}0.396 * * * \\
(18.534)\end{array}$ & $\begin{array}{c}0.314 * * * \\
(6.602)\end{array}$ & $\begin{array}{c}0.157 * * \\
(2.279)\end{array}$ \\
\hline analyst_cov & $\begin{array}{c}0.0150 * * * \\
(5.357)\end{array}$ & $\begin{array}{c}0.00337 * * * \\
(15.62)\end{array}$ & $\begin{array}{c}0.015 * * * \\
(13.365)\end{array}$ & $\begin{array}{c}0.012 * * * \\
(4.252)\end{array}$ & $\begin{array}{c}0.0122 * * * \\
(3.127)\end{array}$ \\
\hline LOSS & $\begin{array}{c}-0.0870 * * * \\
(-9.093)\end{array}$ & $\begin{array}{c}0.0746 * * * \\
(25.54)\end{array}$ & $\begin{array}{c}-0.087 * * * \\
(-7.648)\end{array}$ & $\begin{array}{c}-0.080 * * * * \\
(-7.721)\end{array}$ & $\begin{array}{c}-0.303 * * * \\
(-7.203)\end{array}$ \\
\hline Equity & $\begin{array}{c}-0.00762 \\
(-0.668)\end{array}$ & $\begin{array}{c}-0.00113 \\
(-0.924)\end{array}$ & $\begin{array}{c}-0.034 * * \\
(-2.168)\end{array}$ & $\begin{array}{c}-0.007 \\
(-0.616)\end{array}$ & $\begin{array}{l}-0.0186 \\
(-0.667)\end{array}$ \\
\hline CFVOL & $\begin{array}{c}-0.0349 * * * \\
(-3.175)\end{array}$ & $\begin{array}{l}0.00101 \\
(0.0760)\end{array}$ & $\begin{array}{c}-0.008 \\
(-0.982)\end{array}$ & $\begin{array}{l}-0.018^{*} \\
(-1.868)\end{array}$ & $\begin{array}{c}-0.465 * * \\
(-2.387)\end{array}$ \\
\hline HHI3 & $\begin{array}{c}-0.422 * * \\
(-2.234)\end{array}$ & $\begin{array}{l}0.00351 \\
(0.207)\end{array}$ & $\begin{array}{c}-0.402 * * * \\
(-3.316)\end{array}$ & $\begin{array}{c}-0.303 \\
(-1.492)\end{array}$ & $\begin{array}{c}-1.581 * * * \\
(-2.829)\end{array}$ \\
\hline HHIsq & $\begin{array}{c}0.509^{* *} \\
(2.175)\end{array}$ & $\begin{array}{c}-0.0458^{* *} \\
(-2.077)\end{array}$ & $\begin{array}{c}0.495 * * * \\
(3.441)\end{array}$ & $\begin{array}{c}0.385 \\
(1.531)\end{array}$ & $\begin{array}{l}1.388^{* *} \\
(2.112)\end{array}$ \\
\hline Observations & 95,427 & 65,843 & 95,427 & 95,427 & 25,875 \\
\hline Adjusted R-squared & 0.354 & 0.376 & 0.354 & 0.355 & 0.416 \\
\hline Firm \& Year FE & Yes & Yes & Yes & Yes & Yes \\
\hline
\end{tabular}


Table 7-B: Cross-Sectional Variations in the Effect of IDD on Investment

\begin{tabular}{|c|c|c|c|c|c|}
\hline \multirow[b]{2}{*}{ Variables } & \multicolumn{5}{|c|}{ Investment (=SGA+R\&D+CAPEX) } \\
\hline & (1) & $(2)$ & (3) & $(4)$ & $(5)$ \\
\hline XS Variables $\rightarrow$ & $\begin{array}{c}\text { Trade Secret } \\
\text { Intensity } \\
\end{array}$ & Close Rivals & $\begin{array}{c}\text { Earnings } \\
\text { Uncertainty }\end{array}$ & ERC & CEO Tenure \\
\hline IDD $\times$ XS_Variable & $\begin{array}{c}-0.0316 * * \\
(-2.146)\end{array}$ & $\begin{array}{c}-0.0080 * \\
(-1.960)\end{array}$ & $\begin{array}{c}-0.015 * * * \\
(-3.182)\end{array}$ & $\begin{array}{c}-0.005 * * * \\
(-2.673)\end{array}$ & $\begin{array}{c}0.006 * * \\
(1.969)\end{array}$ \\
\hline IDD & $\begin{array}{c}-0.0141 * * \\
(-2.437)\end{array}$ & $\begin{array}{c}-0.0110 * * \\
(-2.386)\end{array}$ & $\begin{array}{c}-0.021 * * * \\
(-3.586)\end{array}$ & $\begin{array}{c}-0.022 * * * \\
(-3.628)\end{array}$ & $\begin{array}{l}-0.011 * * \\
(-2.353)\end{array}$ \\
\hline XS_Vaiable & & $\begin{array}{c}0.0107 * * * \\
(3.414)\end{array}$ & $\begin{array}{l}0.011 * \\
(1.907)\end{array}$ & $\begin{array}{l}0.002 * * \\
(2.352)\end{array}$ & $\begin{array}{c}0.001 \\
(0.678)\end{array}$ \\
\hline SIZE & $\begin{array}{c}-0.297 * * * \\
(-29.92)\end{array}$ & $\begin{array}{c}-0.254 * * * \\
(-31.45)\end{array}$ & $\begin{array}{c}-0.297 * * * \\
(-29.977)\end{array}$ & $\begin{array}{c}-0.297 * * * \\
(-27.946)\end{array}$ & $\begin{array}{c}-0.0765^{* * *} * \\
(-6.190)\end{array}$ \\
\hline SIZE2 & $\begin{array}{c}0.0131 * * * \\
(15.22)\end{array}$ & $\begin{array}{c}0.00920 * * * \\
(16.19)\end{array}$ & $\begin{array}{c}0.013 * * * \\
(15.299)\end{array}$ & $\begin{array}{c}0.013 * * * \\
(14.214)\end{array}$ & $\begin{array}{c}-0.000368 \\
(-0.486)\end{array}$ \\
\hline AGE & $\begin{array}{c}0.00933 * * * \\
(19.11)\end{array}$ & $\begin{array}{c}0.0101 * * * \\
(15.77)\end{array}$ & $\begin{array}{l}0.009 * * * \\
(15.716)\end{array}$ & $\begin{array}{c}0.009 * * * \\
(17.918)\end{array}$ & $\begin{array}{c}0.00337 * * * \\
(6.396)\end{array}$ \\
\hline $\mathrm{LEVb}$ & $\begin{array}{c}0.140 * * * \\
(12.77)\end{array}$ & $\begin{array}{c}0.0942 * * * \\
(10.84)\end{array}$ & $\begin{array}{c}0.139 * * * \\
(12.741)\end{array}$ & $\begin{array}{c}0.140 * * * \\
(11.974)\end{array}$ & $\begin{array}{c}-0.0493 * * * \\
(-3.552)\end{array}$ \\
\hline inst & $\begin{array}{c}-0.000620 \\
(-0.104)\end{array}$ & $\begin{array}{c}-0.0105 * * * \\
(-2.686)\end{array}$ & $\begin{array}{c}-0.001 \\
(-0.093)\end{array}$ & $\begin{array}{c}-0.001 \\
(-0.134)\end{array}$ & $\begin{array}{c}-0.0205 * * * \\
(-3.798)\end{array}$ \\
\hline analyst_cov & $\begin{array}{c}0.00264 * * * \\
(7.223)\end{array}$ & $\begin{array}{c}0.00337 * * * \\
(15.62)\end{array}$ & $\begin{array}{c}0.003 * * * \\
(7.239)\end{array}$ & $\begin{array}{c}0.003 * * * \\
(6.875)\end{array}$ & $\begin{array}{c}0.00166^{* * *} * \\
(5.511)\end{array}$ \\
\hline LOSS & $\begin{array}{c}0.0817 * * * \\
(18.20)\end{array}$ & $\begin{array}{c}0.0746^{* * *} \\
(25.54)\end{array}$ & $\begin{array}{l}0.082 * * * \\
(18.191)\end{array}$ & $\begin{array}{c}0.082 * * * \\
(17.058)\end{array}$ & $\begin{array}{c}0.0504 * * * \\
(6.456)\end{array}$ \\
\hline Equity & $\begin{array}{c}0.00771^{* * *} * \\
(3.419)\end{array}$ & $\begin{array}{c}-0.00113 \\
(-0.924)\end{array}$ & $\begin{array}{c}0.036 * * * \\
(2.919)\end{array}$ & $\begin{array}{c}0.008 * * * \\
(3.265)\end{array}$ & $\begin{array}{c}-0.00432 * * \\
(-2.092)\end{array}$ \\
\hline CFVOL & $\begin{array}{c}0.0358 * * * \\
(2.925)\end{array}$ & $\begin{array}{l}0.00101 \\
(0.0760)\end{array}$ & $\begin{array}{c}0.008 * * * \\
(3.394)\end{array}$ & $\begin{array}{c}0.036 * * * \\
(2.716)\end{array}$ & $\begin{array}{l}0.0235 \\
(0.545)\end{array}$ \\
\hline HHI3 & $\begin{array}{c}-0.356^{* * *} \\
(-6.700)\end{array}$ & $\begin{array}{c}0.00351 \\
(0.207)\end{array}$ & $\begin{array}{c}-0.353 * * * \\
(-6.647)\end{array}$ & $\begin{array}{c}-0.355^{* * * *} \\
(-6.212)\end{array}$ & $\begin{array}{c}-0.171^{* * * *} \\
(-3.334)\end{array}$ \\
\hline HHIsq & $\begin{array}{c}0.210 * * * \\
(3.783)\end{array}$ & $\begin{array}{c}-0.0458 * * \\
(-2.077)\end{array}$ & $\begin{array}{c}0.207 * * * \\
(3.729)\end{array}$ & $\begin{array}{c}0.203 * * * \\
(3.387)\end{array}$ & $\begin{array}{c}0.166 * * * \\
(3.157)\end{array}$ \\
\hline Observations & 95,427 & 65,843 & 95,427 & 95,427 & 25,875 \\
\hline Adjusted R-squared & 0.722 & 0.775 & 0.722 & 0.722 & 0.850 \\
\hline Firm \& Year FE & Yes & Yes & Yes & Yes & Yes \\
\hline
\end{tabular}


The table reports the results from cross-sectional analyses. Panel $A$ reports the effects of IDD on annual guidance and Panel $B$ the effects of IDD on investments.

IDD (Inevitable Disclosure Doctrine) equals one for all fiscal years greater than or equal to the IDD-adoption year for firms located in adopting states, and zero otherwise. Investment equals the sum of SGA, R\&D, and CAPEX, scaled by the book value of assets. Trade Secret Intensity is an indicator variable for firms in Computers, Electronics, Petroleum, Chemical, Drugs, and Scientific research and development services industries. Close Rivals is an indicator variable that takes one if a firm has greater than Fama-French 48 industry-year median close rivals, zero otherwise. Earnings Uncertainty is defined as the standard deviation of earnings at the Fama-French 48 industry-year level. ERC is earnings-response coefficient estimated at the Fama-French 48 industry-year level. CEO Tenure is the number of years the current CEO is in office.

The sample period ranges from 1994 to 2011. Test statistics (two-sided) based on robust standard errors clustered at the firm level are reported in parenthesis. Asterisks ***,**, and * indicate statistical significance at the $1 \%, 5 \%$, and $10 \%$ level respectively. 
Table 8: The Effects of Rejection of IDD on Guidance and Myopic Underinvestment

\begin{tabular}{|c|c|c|c|c|c|}
\hline \multirow[b]{2}{*}{ Variables } & \multicolumn{2}{|c|}{ Annual Guidance } & \multicolumn{3}{|c|}{ Investments } \\
\hline & $\begin{array}{c}(1) \\
\text { Number }\end{array}$ & $\begin{array}{c}(2) \\
\text { Indicator } \\
\end{array}$ & $\begin{array}{c}(3) \\
S G A_{t}\end{array}$ & $\begin{array}{c}(4) \\
R \& D_{t}\end{array}$ & $\begin{array}{c}(5) \\
C A P E X_{t}\end{array}$ \\
\hline Reject IDD & $\begin{array}{c}-0.107 * * \\
(-2.168)\end{array}$ & $\begin{array}{l}-0.019 * \\
(-1.711)\end{array}$ & $\begin{array}{c}0.007 \\
(\mathbf{0 . 9 3 3 )}\end{array}$ & $\begin{array}{c}0.005 * * \\
(2.003)\end{array}$ & $\begin{array}{l}0.004 * \\
(1.921)\end{array}$ \\
\hline Size & $\begin{array}{c}-0.198 * * * \\
(-7.781)\end{array}$ & $\begin{array}{c}-0.0139 * * \\
(-2.503)\end{array}$ & $\begin{array}{c}-0.276 * * * \\
(-26.70)\end{array}$ & $\begin{array}{c}-0.0797 * * * \\
(-21.42)\end{array}$ & $\begin{array}{c}-0.00127 \\
(-0.914)\end{array}$ \\
\hline Size-Squared & $\begin{array}{c}0.0345 * * * \\
(10.32)\end{array}$ & $\begin{array}{c}0.00402^{* * * *} \\
(5.651)\end{array}$ & $\begin{array}{c}0.0130 * * * \\
(14.22)\end{array}$ & $\begin{array}{c}0.00408 * * * \\
(13.51)\end{array}$ & $\begin{array}{c}-0.000139 \\
(-1.071)\end{array}$ \\
\hline Age & $\begin{array}{c}0.0467 * * * \\
(17.37)\end{array}$ & $\begin{array}{c}0.00824 * * * \\
(13.31)\end{array}$ & $\begin{array}{c}0.0129 * * * \\
(21.66)\end{array}$ & $\begin{array}{c}0.00275^{* * * *} \\
(12.03)\end{array}$ & $\begin{array}{c}-0.00173 * * * \\
(-14.82)\end{array}$ \\
\hline Leverage & $\begin{array}{c}-0.218 * * * \\
(-5.897)\end{array}$ & $\begin{array}{c}-0.0484 * * * \\
(-5.392)\end{array}$ & $\begin{array}{c}0.117 * * * \\
(10.18)\end{array}$ & $\begin{array}{c}0.0328 * * * \\
(7.749)\end{array}$ & $\begin{array}{c}0.00303 \\
(1.260)\end{array}$ \\
\hline InstOwn & $\begin{array}{c}0.382 * * * \\
(7.129)\end{array}$ & $\begin{array}{c}0.105 * * * \\
(8.422)\end{array}$ & $\begin{array}{c}-0.00130 \\
(-0.239)\end{array}$ & $\begin{array}{c}0.00163 \\
(0.797)\end{array}$ & $\begin{array}{c}-0.000153 \\
(-0.102)\end{array}$ \\
\hline \#Analyst & $\begin{array}{c}0.0175 * * * \\
(5.284)\end{array}$ & $\begin{array}{c}0.00578 * * * \\
(7.841)\end{array}$ & $\begin{array}{c}0.00170 * * * \\
(4.905)\end{array}$ & $\begin{array}{c}0.000244^{*} \\
(1.916)\end{array}$ & $\begin{array}{c}0.000661 * * * \\
(7.205)\end{array}$ \\
\hline Loss & $\begin{array}{c}-0.0900 * * * \\
(-7.787)\end{array}$ & $\begin{array}{c}-0.0270 * * * \\
(-7.993)\end{array}$ & $\begin{array}{c}0.0660 * * * \\
(15.07)\end{array}$ & $\begin{array}{c}0.0176 * * * \\
(11.59)\end{array}$ & $\begin{array}{c}0.00336 * * * \\
(3.703)\end{array}$ \\
\hline Equity & $\begin{array}{l}-0.0151 \\
(-1.123)\end{array}$ & $\begin{array}{c}-0.00154 \\
(-0.474)\end{array}$ & $\begin{array}{c}0.000569 \\
(0.261)\end{array}$ & $\begin{array}{c}0.00486^{* * * *} \\
(6.760)\end{array}$ & $\begin{array}{c}0.00406^{* * * *} \\
(7.626)\end{array}$ \\
\hline EarnVol & $\begin{array}{c}-0.0236 * \\
(-1.672)\end{array}$ & $\begin{array}{c}-0.00769 * * \\
(-2.237)\end{array}$ & $\begin{array}{l}0.0130 \\
(0.989)\end{array}$ & $\begin{array}{c}0.0148 * * * \\
(3.054)\end{array}$ & $\begin{array}{c}0.00454 * * \\
(2.419)\end{array}$ \\
\hline $\mathrm{HHI}$ & $\begin{array}{l}-0.416^{*} \\
(-1.798)\end{array}$ & $\begin{array}{l}-0.120 * * \\
(-2.103)\end{array}$ & $\begin{array}{c}-0.252 * * * \\
(-4.500)\end{array}$ & $\begin{array}{c}-0.129 * * * \\
(-7.357)\end{array}$ & $\begin{array}{c}-0.0473 * * * \\
(-4.074)\end{array}$ \\
\hline HHI-Squared & $\begin{array}{c}0.403 \\
(1.478)\end{array}$ & $\begin{array}{l}0.123 * \\
(1.762)\end{array}$ & $\begin{array}{c}0.154 * * * \\
(2.697)\end{array}$ & $\begin{array}{c}0.0951 * * * \\
(5.393)\end{array}$ & $\begin{array}{c}0.0390 * * * \\
(2.980)\end{array}$ \\
\hline Observations & 65,413 & 65,413 & 65,413 & 65,413 & 65,413 \\
\hline Adjusted R-squared & 0.347 & 0.316 & 0.748 & 0.766 & 0.566 \\
\hline Firm FE & Yes & Yes & Yes & Yes & Yes \\
\hline Year FE & Yes & Yes & Yes & Yes & Yes \\
\hline
\end{tabular}


The table reports the OLS estimates for the effect of state rejection of Inevitable Disclosure Doctrine (after having previously adopted it) on the annual management earnings forecast incidence and frequency as well as on myopic underinvestment. Reject IDD equals one for all fiscal years greater than or equal to the IDD-rejection year for firms located in rejecting states, and zero otherwise. SGA, R\&D, CAPEX are the selling, general, admin and advertising expenses, research and development expenditures and capital expenditures respectively, scaled by the book value of assets. The sample period ranges from 1997 to 2008. Test statistics (twosided) based on robust standard errors clustered at the firm level are reported in parenthesis. Asterisks $* * *, * *$, and * indicate statistical significance at the $1 \%, 5 \%$, and $10 \%$ level respectively. See Appendix B for variable definitions. 
Table 9-A: Falsification Test 1 - IDD and Guidance (Sample Period: 1980-1990)

\begin{tabular}{|c|c|c|c|}
\hline \multirow[b]{3}{*}{ Variables } & \multicolumn{3}{|c|}{ Number of Numerical Forecasts } \\
\hline & (1) & (2) & (3) \\
\hline & All & Only Annual & Only Quarterly \\
\hline IDD & $\begin{array}{c}0.00531 \\
(0.144)\end{array}$ & $\begin{array}{c}0.00716 \\
(0.240)\end{array}$ & $\begin{array}{c}-0.00185 \\
(-0.149)\end{array}$ \\
\hline Size & $\begin{array}{l}0.0253 \\
(0.108)\end{array}$ & $\begin{array}{l}0.0294 \\
(0.146)\end{array}$ & $\begin{array}{l}-0.00402 \\
(-0.0485)\end{array}$ \\
\hline Size-Squared & $\begin{array}{l}-5.41 e-05 \\
(-0.00362)\end{array}$ & $\begin{array}{c}-0.000468 \\
(-0.0359)\end{array}$ & $\begin{array}{c}0.000413 \\
(0.0796)\end{array}$ \\
\hline Age & $\begin{array}{c}0.00726 \\
(1.198)\end{array}$ & $\begin{array}{c}0.00480 \\
(0.935)\end{array}$ & $\begin{array}{c}0.00246 \\
(1.198)\end{array}$ \\
\hline Leverage & $\begin{array}{c}0.110 \\
(0.895)\end{array}$ & $\begin{array}{l}0.0721 \\
(0.675)\end{array}$ & $\begin{array}{l}0.0378 \\
(1.141)\end{array}$ \\
\hline InstOwn & $\begin{array}{l}0.00336 \\
(0.0220)\end{array}$ & $\begin{array}{l}-0.0224 \\
(-0.147)\end{array}$ & $\begin{array}{l}0.0258 \\
(0.933)\end{array}$ \\
\hline \#Analyst & $\begin{array}{c}0.00697 * \\
(1.800)\end{array}$ & $\begin{array}{c}0.00578 * \\
(1.710)\end{array}$ & $\begin{array}{c}0.00119 \\
(0.770)\end{array}$ \\
\hline Loss & $\begin{array}{c}-0.000753 \\
(-0.0478)\end{array}$ & $\begin{array}{c}0.000196 \\
(0.0154)\end{array}$ & $\begin{array}{c}-0.000949 \\
(-0.186)\end{array}$ \\
\hline Equity & $\begin{array}{l}-0.00117 \\
(-0.0609)\end{array}$ & $\begin{array}{c}-0.00242 \\
(-0.158)\end{array}$ & $\begin{array}{c}0.00125 \\
(0.143)\end{array}$ \\
\hline EarnVol & $\begin{array}{l}0.0249 \\
(1.216)\end{array}$ & $\begin{array}{l}0.0157 \\
(1.079)\end{array}$ & $\begin{array}{c}0.00920 \\
(1.212)\end{array}$ \\
\hline HHI & $\begin{array}{l}1.701 * \\
(1.731)\end{array}$ & $\begin{array}{l}1.502 * \\
(1.802)\end{array}$ & $\begin{array}{c}0.199 \\
(0.744)\end{array}$ \\
\hline HHI-Squared & $\begin{array}{c}-1.657 \\
(-1.521)\end{array}$ & $\begin{array}{c}-1.547 \\
(-1.624)\end{array}$ & $\begin{array}{c}-0.110 \\
(-0.358)\end{array}$ \\
\hline Observations & 2,682 & 2,682 & 2,682 \\
\hline Adjusted R-squared & 0.177 & 0.160 & 0.098 \\
\hline Firm FE & Yes & Yes & Yes \\
\hline Year FE & Yes & Yes & Yes \\
\hline
\end{tabular}


Table 9-B: Falsification Test 1 - IDD and Investments (Sample Period: 1980-1990)

\begin{tabular}{|c|c|c|c|}
\hline Variables & $\begin{array}{c}(1) \\
S G A_{t} \\
\end{array}$ & $\begin{array}{c}(2) \\
R \& D_{t} \\
\end{array}$ & $\begin{array}{c}(3) \\
C A P E X_{t} \\
\end{array}$ \\
\hline IDD & $\begin{array}{c}0.0110 * \\
(1.885)\end{array}$ & $\begin{array}{c}0.00221 * * \\
(2.189)\end{array}$ & $\begin{array}{c}0.00579 * \\
(1.940)\end{array}$ \\
\hline Size & $\begin{array}{l}0.0911 \\
(1.506)\end{array}$ & $\begin{array}{c}0.00349 \\
(0.421)\end{array}$ & $\begin{array}{c}0.0848 * * \\
(2.486)\end{array}$ \\
\hline Size-Squared & $\begin{array}{c}-0.00915^{* *} \\
(-2.321)\end{array}$ & $\begin{array}{c}-0.000403 \\
(-0.685)\end{array}$ & $\begin{array}{c}-0.00511^{* *} \\
(-2.525)\end{array}$ \\
\hline Age & $\begin{array}{c}0.00235^{* *} * \\
(2.281)\end{array}$ & $\begin{array}{c}0.000208 \\
(1.380)\end{array}$ & $\begin{array}{c}-0.00304 * * * \\
(-5.377)\end{array}$ \\
\hline Leverage & $\begin{array}{c}-0.0876 * * * \\
(-3.351)\end{array}$ & $\begin{array}{c}-0.00853^{* *} \\
(-2.158)\end{array}$ & $\begin{array}{c}-0.0370 * * \\
(-2.202)\end{array}$ \\
\hline InstOwn & $\begin{array}{c}-0.00467 \\
(-0.229)\end{array}$ & $\begin{array}{c}0.000296 \\
(0.0884)\end{array}$ & $\begin{array}{l}0.0121 \\
(0.838)\end{array}$ \\
\hline \#Analyst & $\begin{array}{l}-6.78 \mathrm{e}-05 \\
(-0.200)\end{array}$ & $\begin{array}{c}6.08 \mathrm{e}-05 \\
(1.170)\end{array}$ & $\begin{array}{c}0.000166 \\
(0.785)\end{array}$ \\
\hline Loss & $\begin{array}{c}0.00697 \\
(0.508)\end{array}$ & $\begin{array}{c}0.00290 \\
(1.373)\end{array}$ & $\begin{array}{c}-0.00842 \\
(-1.298)\end{array}$ \\
\hline Equity & $\begin{array}{c}-0.00186 \\
(-0.618)\end{array}$ & $\begin{array}{c}-0.000900 * * \\
(-2.057)\end{array}$ & $\begin{array}{c}0.00686 * * * \\
(3.722)\end{array}$ \\
\hline EarnVol & $\begin{array}{l}0.00167 \\
(1.294)\end{array}$ & $\begin{array}{c}0.00102 * * * \\
(4.136)\end{array}$ & $\begin{array}{c}0.000744 \\
(0.844)\end{array}$ \\
\hline HHI & $\begin{array}{c}0.0155 \\
(0.0956)\end{array}$ & $\begin{array}{c}-0.000952 \\
(-0.0416)\end{array}$ & $\begin{array}{c}0.0876^{* *} \\
(2.033)\end{array}$ \\
\hline HHI-Squared & $\begin{array}{l}0.0894 \\
(0.482)\end{array}$ & $\begin{array}{l}0.00218 \\
(0.0852)\end{array}$ & $\begin{array}{l}-0.0824 \\
(-1.475)\end{array}$ \\
\hline Observations & 2,682 & 2,682 & 2,682 \\
\hline Adjusted R-squared & 0.954 & 0.945 & 0.601 \\
\hline Firm FE & Yes & Yes & Yes \\
\hline Year FE & Yes & Yes & Yes \\
\hline
\end{tabular}


The table reports results from falsification test 1 (sample period 1980-1990). Firms with assets greater than 500 million USD and located in IDD-adopting states (treatment firms) and states contiguous to the IDD-adopting states (control firms) are included in the sample. Guidance data are hand-collected from Factiva. Panel $A$ reports estimates for the effect of state adoption of Inevitable Disclosure Doctrine (IDD) on management forecasts. Panel $B$ reports the estimates for the effect of IDD on SGA, R\&D, and CAPEX, which are the selling, general, admin and advertising expenses, research and development expenditures and capital expenditures respectively, scaled by the book value of assets. All specifications are estimated using the OLS regression. Test statistics (two-sided) based on robust standard errors clustered at the firm level are reported in parenthesis. Asterisks $* * *, * *$, and * indicate statistical significance at the 1\%, 5\%, and 10\% level respectively. See Appendix B for variable definitions. 
Table 10: Falsification Test 2 - IDD and Investments of SEC-registered Private Firms

\begin{tabular}{|c|c|c|c|}
\hline Variables & $\begin{array}{c}(1) \\
S G A_{t} \\
\end{array}$ & $\begin{array}{c}(2) \\
R \& D_{t} \\
\end{array}$ & $\begin{array}{c}(3) \\
C A P E X_{t}\end{array}$ \\
\hline IDD & $\begin{array}{c}0.00165 \\
(0.303)\end{array}$ & $\begin{array}{c}0.000394 \\
(1.158)\end{array}$ & $\begin{array}{c}0.00677 * * \\
(2.524)\end{array}$ \\
\hline Size & $\begin{array}{c}-0.147 * * * \\
(-4.361)\end{array}$ & $\begin{array}{c}-0.0358 * * * \\
(-2.875)\end{array}$ & $\begin{array}{l}-0.0101 * \\
(-1.824)\end{array}$ \\
\hline Size-Squared & $\begin{array}{c}0.00559 * * * \\
(3.501)\end{array}$ & $\begin{array}{c}0.00170 * * * \\
(3.315)\end{array}$ & $\begin{array}{c}0.000197 \\
(0.664)\end{array}$ \\
\hline Age & $\begin{array}{c}0.00333 * * * \\
(4.420)\end{array}$ & $\begin{array}{c}0.000379 \\
(1.500)\end{array}$ & $\begin{array}{c}0.000466 \\
(1.485)\end{array}$ \\
\hline Leverage & $\begin{array}{c}0.0858 * * * \\
(2.622)\end{array}$ & $\begin{array}{c}0.0159 * * * \\
(3.481)\end{array}$ & $\begin{array}{l}0.0198 \\
(1.275)\end{array}$ \\
\hline Loss & $\begin{array}{c}0.00552 \\
(0.297)\end{array}$ & $\begin{array}{c}0.00200 \\
(0.851)\end{array}$ & $\begin{array}{c}-0.00278 \\
(-0.643)\end{array}$ \\
\hline Equity & $\begin{array}{c}0.00410 \\
(0.801)\end{array}$ & $\begin{array}{c}-0.000391 \\
(-0.263)\end{array}$ & $\begin{array}{c}0.00478 * \\
(1.875)\end{array}$ \\
\hline EarnVol & $\begin{array}{c}0.507 * * \\
(2.043)\end{array}$ & $\begin{array}{c}0.0780 * * * \\
(3.455)\end{array}$ & $\begin{array}{c}0.0809 * * \\
(2.372)\end{array}$ \\
\hline HHI & $\begin{array}{c}-0.154 \\
(-1.301)\end{array}$ & $\begin{array}{l}-0.0167 \\
(-0.852)\end{array}$ & $\begin{array}{l}-0.118 * \\
(-1.764)\end{array}$ \\
\hline HHI-Squared & $\begin{array}{l}0.0611 \\
(0.506)\end{array}$ & $\begin{array}{l}-0.0121 \\
(-0.742)\end{array}$ & $\begin{array}{l}0.104 * \\
(1.702)\end{array}$ \\
\hline $\begin{array}{l}\text { Observations } \\
\text { Adjusted R-squared } \\
\text { Firm \& Year FE }\end{array}$ & $\begin{array}{c}8,266 \\
0.969 \\
\text { Yes }\end{array}$ & $\begin{array}{l}8,209 \\
0.982 \\
\text { Yes }\end{array}$ & $\begin{array}{l}8,209 \\
0.753 \\
\text { Yes }\end{array}$ \\
\hline
\end{tabular}


The table reports results from falsification test 2 (sample period 1994-2011). Only firms that have public debt but no public equity as well as large private firms that are subject to SEC filing requirements are included in the sample. IDD (Inevitable Disclosure Doctrine) equals one for all fiscal years greater than or equal to the IDD-adoption year for firms located in adopting states, and zero otherwise. SGA, R\&D, and CAPEX are the selling, general, admin and advertising expenses, research and development expenditures and capital expenditures respectively, scaled by the book value of assets. All specifications are estimated using the OLS regression. Test statistics (two-sided) based on robust standard errors clustered at the firm level are reported in parenthesis. Asterisks $* * *, * *$, and $*$ indicate statistical significance at the $1 \%$, $5 \%$, and $10 \%$ level respectively. See Appendix B for variable definitions. 
Table 11-A: Guidance to Revise Down Expectations and Investments

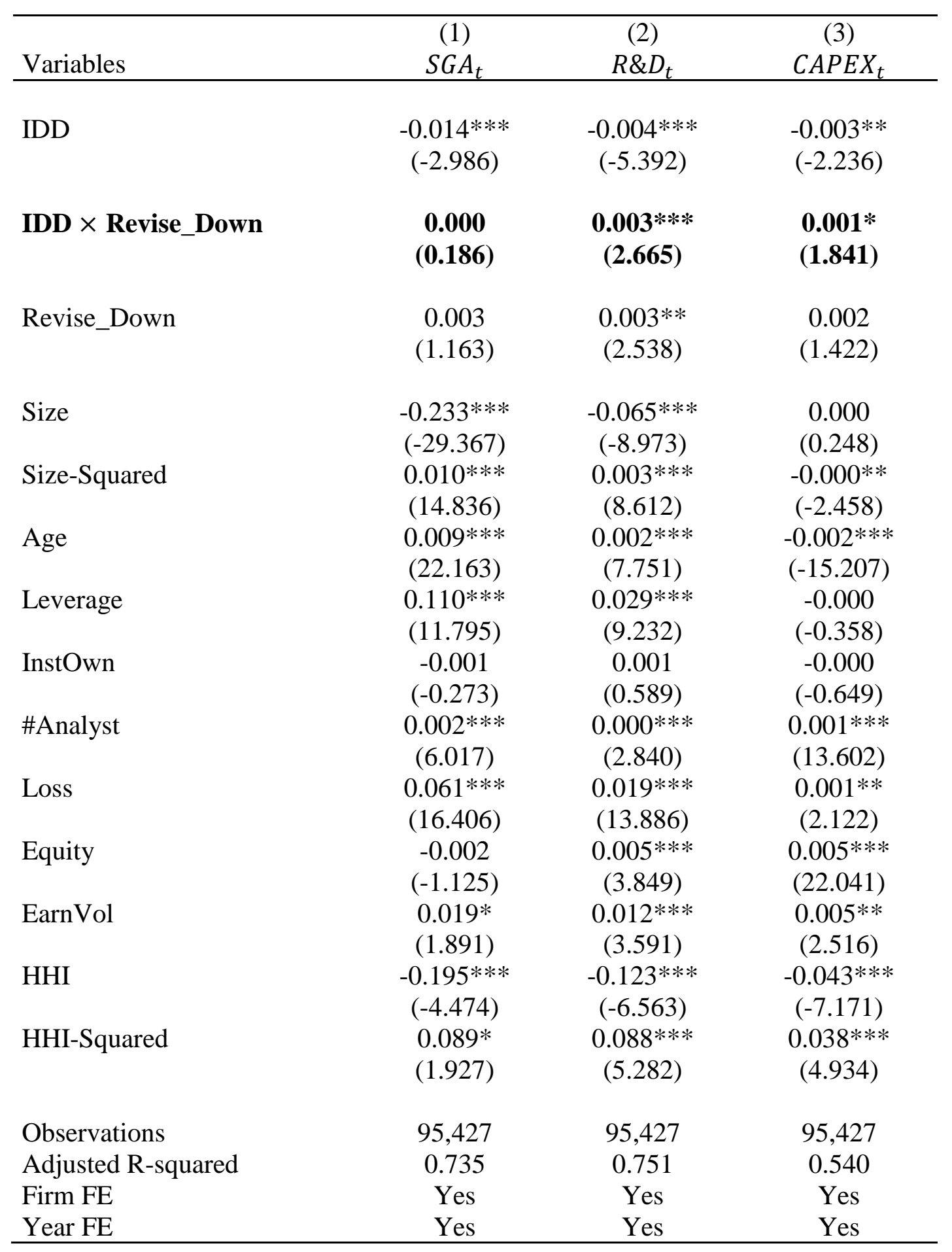


Table 11-B: Guidance to Revise Up or Confirm Expectations and Investment

\begin{tabular}{|c|c|c|c|}
\hline Variables & $\begin{array}{c}(1) \\
S G A_{t} \\
\end{array}$ & $\begin{array}{c}(2) \\
R \& D_{t} \\
\end{array}$ & $\begin{array}{c}(3) \\
C A P E X_{t}\end{array}$ \\
\hline IDD & $\begin{array}{l}-0.013 * \\
(-1.931)\end{array}$ & $\begin{array}{c}-0.005^{* *} \\
(-2.509)\end{array}$ & $\begin{array}{l}-0.004 * \\
(-1.962)\end{array}$ \\
\hline IDD $\times$ Confirm/Revise_Up & $\begin{array}{c}-0.007 \\
(-1.268)\end{array}$ & $\begin{array}{c}-0.000 \\
(-0.0445)\end{array}$ & $\begin{array}{c}0.001 \\
(0.547)\end{array}$ \\
\hline Confirm/Revise_Up & $\begin{array}{c}-0.004 \\
(-1.100)\end{array}$ & $\begin{array}{l}0.002 * \\
(1.857)\end{array}$ & $\begin{array}{c}0.003 * * * \\
(4.027)\end{array}$ \\
\hline Size & $\begin{array}{c}-0.233 * * * \\
(-15.064)\end{array}$ & $\begin{array}{c}-0.065 * * * \\
(-6.119)\end{array}$ & $\begin{array}{c}0.000 \\
(0.358)\end{array}$ \\
\hline Size-Squared & $\begin{array}{c}0.010 * * * \\
(11.599)\end{array}$ & $\begin{array}{c}0.003 * * * \\
(6.959)\end{array}$ & $\begin{array}{c}-0.000 * * * \\
(-3.997)\end{array}$ \\
\hline Age & $\begin{array}{c}0.009 * * * \\
(10.467)\end{array}$ & $\begin{array}{c}0.002 * * * \\
(5.285)\end{array}$ & $\begin{array}{c}-0.002 * * * \\
(-12.575)\end{array}$ \\
\hline Leverage & $\begin{array}{c}0.110 * * * \\
(7.274)\end{array}$ & $\begin{array}{c}0.029 * * * \\
(3.455)\end{array}$ & $\begin{array}{c}0.000 \\
(0.013)\end{array}$ \\
\hline InstOwn & $\begin{array}{c}-0.001 \\
(-0.107)\end{array}$ & $\begin{array}{c}0.001 \\
(0.449)\end{array}$ & $\begin{array}{c}-0.000 \\
(-0.183)\end{array}$ \\
\hline \#Analyst & $\begin{array}{c}0.002 * * * \\
(4.741)\end{array}$ & $\begin{array}{c}0.000 \\
(1.324)\end{array}$ & $\begin{array}{c}0.001 * * * \\
(6.535)\end{array}$ \\
\hline Loss & $\begin{array}{c}0.061 * * * \\
(13.085)\end{array}$ & $\begin{array}{c}0.019 * * * \\
(5.545)\end{array}$ & $\begin{array}{c}0.001 \\
(1.192)\end{array}$ \\
\hline Equity & $\begin{array}{c}-0.002 \\
(-0.855)\end{array}$ & $\begin{array}{c}0.005 * * * \\
(4.457)\end{array}$ & $\begin{array}{c}0.005^{* * * *} \\
(8.041)\end{array}$ \\
\hline EarnVol & $\begin{array}{c}0.019 * * \\
(2.338)\end{array}$ & $\begin{array}{c}0.011 * * * \\
(2.834)\end{array}$ & $\begin{array}{c}0.005^{* *} \\
(2.595)\end{array}$ \\
\hline HHI & $\begin{array}{c}-0.194 * * * \\
(-3.234)\end{array}$ & $\begin{array}{c}-0.122 * * * \\
(-5.000)\end{array}$ & $\begin{array}{c}-0.043 * * * \\
(-3.201)\end{array}$ \\
\hline HHI-Squared & $\begin{array}{c}0.088 \\
(1.442)\end{array}$ & $\begin{array}{c}0.087 * * * \\
(4.890)\end{array}$ & $\begin{array}{c}0.038 * * \\
(2.450)\end{array}$ \\
\hline Observations & 95,427 & 95,427 & 95,427 \\
\hline Adjusted R-squared & 0.735 & 0.750 & 0.541 \\
\hline Firm FE & Yes & Yes & Yes \\
\hline Year FE & Yes & Yes & Yes \\
\hline
\end{tabular}


The table reports the OLS estimates for the effect of state adoption of Inevitable Disclosure Doctrine (IDD) on investment conditional on revising or confirming market expectations set by previous guidance. Revise_Down in Panel A (Confirm/Revise_Up in Panel B) is an indicator variable that takes one if firms revise down (confirm or revise up) guidance subsequently after having previously providing guidance early in the year, zero otherwise. IDD equals one for all fiscal years greater than or equal to the IDD-adoption year for firms located in adopting states, and zero otherwise. SGA, R\&D, CAPEX are the selling, general, admin and advertising expenses, research and development expenditures and capital expenditures respectively, scaled by the book value of assets. Test statistics (two-sided) based on robust standard errors clustered at the firm level are reported in parenthesis. Asterisks $* * *, * *$, and * indicate statistical significance at the $1 \%, 5 \%$, and $10 \%$ level respectively. See Appendix B for variable definitions. 
Table 12: Does Myopic Underinvestment Help Firms Meet or Beat Earnings Guidance?

\begin{tabular}{|c|c|c|}
\hline Variables & $\begin{array}{c}\text { (1) } \\
\text { Meet or Beat } \\
\end{array}$ & $\begin{array}{c}(2) \\
\text { Meet or Barely Beat }\end{array}$ \\
\hline IDD & $\begin{array}{c}0.0198 * * * \\
(4.018)\end{array}$ & $\begin{array}{l}0.0129 * * * \\
(3.169)\end{array}$ \\
\hline Size & $\begin{array}{c}-0.0380 * * * \\
(-7.976)\end{array}$ & $\begin{array}{c}-0.0249 * * * \\
(-6.205)\end{array}$ \\
\hline Size-Squared & $\begin{array}{c}0.00581 * * * \\
(9.620)\end{array}$ & $\begin{array}{c}0.00400 * * * \\
(7.990)\end{array}$ \\
\hline Age & $\begin{array}{c}0.00392 * * * \\
(9.966)\end{array}$ & $\begin{array}{c}0.00230 * * * \\
(6.828)\end{array}$ \\
\hline Leverage & $\begin{array}{c}-0.0316^{* * *} \\
(-5.093)\end{array}$ & $\begin{array}{c}-0.0202 * * * \\
(-3.949)\end{array}$ \\
\hline InstOwn & $\begin{array}{c}0.0822 * * * \\
(9.013)\end{array}$ & $\begin{array}{c}0.0646 * * * \\
(7.807)\end{array}$ \\
\hline \#Analyst & $\begin{array}{l}0.00271 * * * \\
(4.812)\end{array}$ & $\begin{array}{l}0.00206 * * * \\
(4.383)\end{array}$ \\
\hline Loss & $\begin{array}{c}-0.0235 * * * \\
(-9.947)\end{array}$ & $\begin{array}{c}-0.0182 * * * \\
(-9.096)\end{array}$ \\
\hline Equity & $\begin{array}{c}-0.00312 \\
(-1.341)\end{array}$ & $\begin{array}{c}-0.00225 \\
(-1.111)\end{array}$ \\
\hline EarnVol & $\begin{array}{c}-0.00633 * * \\
(-2.352)\end{array}$ & $\begin{array}{c}-0.00481 * * \\
(-2.548)\end{array}$ \\
\hline HHI & $\begin{array}{l}-0.0540 \\
(-1.435)\end{array}$ & $\begin{array}{l}-0.0404 \\
(-1.243)\end{array}$ \\
\hline HHI-Squared & $\begin{array}{l}0.0508 \\
(1.073)\end{array}$ & $\begin{array}{l}0.0359 \\
(0.868)\end{array}$ \\
\hline Observations & 95,427 & 95,427 \\
\hline Adjusted R-squared & 0.237 & 0.174 \\
\hline Firm FE & Yes & Yes \\
\hline Year FE & Yes & Yes \\
\hline
\end{tabular}


The table shows that treatments firms are more likely to meet or beat annual earnings guidance than control firms following the state adoption of IDD. Meet or Beat is an indicator variable that equals one if firms meet or beat annual earnings guidance, zero otherwise. Meet or Barely Beat is an indicator variable that equals one if firms meet or beat annual earnings guidance within ten cents, zero otherwise. IDD (Inevitable Disclosure Doctrine) equals one for all fiscal years greater than or equal to the IDD-adoption year for firms located in adopting states, and zero otherwise. All specifications are estimated using the OLS regression. Test statistics (twosided) based on robust standard errors clustered at the firm level are reported in parenthesis. Asterisks $* * *, * *$, and $*$ indicate statistical significance at the $1 \%, 5 \%$, and $10 \%$ level respectively. See Appendix B for variable definitions. 
Table 13-A: Alternative Explanations - Compensation and Risk-Taking Incentives

\begin{tabular}{|c|c|c|c|}
\hline Variables & $\begin{array}{c}(1) \\
\log \text { Delta }\end{array}$ & $\begin{array}{c}(2) \\
\log V e g a \\
\end{array}$ & $\begin{array}{c}\text { (3) } \\
\operatorname{logEquity} \\
\end{array}$ \\
\hline IDD & $\begin{array}{c}-0.008 \\
(-0.205)\end{array}$ & $\begin{array}{c}0.126 * * * \\
(2.661)\end{array}$ & $\begin{array}{c}-0.031 \\
(-0.654)\end{array}$ \\
\hline Size & $\begin{array}{c}0.253 * * * \\
(4.113)\end{array}$ & $\begin{array}{c}0.266 * * * \\
(3.559)\end{array}$ & $\begin{array}{c}0.299 * * * \\
(4.637)\end{array}$ \\
\hline Size-Squared & $\begin{array}{c}0.013 * * * \\
(3.003)\end{array}$ & $\begin{array}{c}0.018 * * * \\
(3.307)\end{array}$ & $\begin{array}{c}0.010 * * \\
(2.196)\end{array}$ \\
\hline Age & $\begin{array}{c}-0.024 * * * \\
(-7.455)\end{array}$ & $\begin{array}{c}0.002 \\
(0.689)\end{array}$ & $\begin{array}{c}-0.027 * * * \\
(-7.407)\end{array}$ \\
\hline Leverage & $\begin{array}{c}-1.268 * * * \\
(-14.564)\end{array}$ & $\begin{array}{c}-0.573 * * * \\
(-6.491)\end{array}$ & $\begin{array}{c}-1.454 * * * \\
(-14.615)\end{array}$ \\
\hline InstOwn & $\begin{array}{c}0.099 * * * \\
(2.697)\end{array}$ & $\begin{array}{c}-0.009 \\
(-0.207)\end{array}$ & $\begin{array}{c}0.131 * * * \\
(3.139)\end{array}$ \\
\hline \#Analyst & $\begin{array}{c}0.008 * * * \\
(3.662)\end{array}$ & $\begin{array}{c}0.007 * * * \\
(3.029)\end{array}$ & $\begin{array}{c}0.009 * * * \\
(3.789)\end{array}$ \\
\hline Loss & $\begin{array}{c}-0.518 * * * \\
(-14.189)\end{array}$ & $\begin{array}{c}-0.255^{* * *} \\
(-7.944)\end{array}$ & $\begin{array}{c}-0.624 * * * \\
(-14.232)\end{array}$ \\
\hline Equity & $\begin{array}{c}0.109 * * * \\
(7.216)\end{array}$ & $\begin{array}{c}-0.014 \\
(-0.857)\end{array}$ & $\begin{array}{c}0.144 * * * \\
(8.406)\end{array}$ \\
\hline EarnVol & $\begin{array}{c}0.799 * * * \\
(3.376)\end{array}$ & $\begin{array}{c}-0.132 \\
(-0.740)\end{array}$ & $\begin{array}{c}0.950 * * * \\
(3.462)\end{array}$ \\
\hline HHI & $\begin{array}{c}-0.754 * * \\
(-2.279)\end{array}$ & $\begin{array}{c}-0.499 \\
(-1.313)\end{array}$ & $\begin{array}{l}-0.689^{*} \\
(-1.856)\end{array}$ \\
\hline HHI-Squared & $\begin{array}{l}0.696 * \\
(1.847)\end{array}$ & $\begin{array}{c}0.458 \\
(0.981)\end{array}$ & $\begin{array}{c}0.631 \\
(1.485)\end{array}$ \\
\hline Observations & 126,882 & 132,735 & 126,882 \\
\hline Adjusted R-squared & 0.438 & 0.549 & 0.412 \\
\hline Firm FE & Yes & Yes & Yes \\
\hline Year FE & Yes & Yes & Yes \\
\hline
\end{tabular}


The table tests whether managerial compensation could explain the myopic underinvestment. logDelta, logVega and logEquity measure pay-performance sensitivity, risk-taking incentives and managers' inside equity. IDD (Inevitable Disclosure Doctrine) equals one for all fiscal years greater than or equal to the IDD-adoption year for firms located in adopting states, and zero otherwise. The sample period ranges from 1994-2011. The analyses are conducted at the firm-executive-year level. Test statistics (two-sided) based on robust standard errors clustered at the firm level are reported in parenthesis. Asterisks ***,**, and * indicate statistical significance at the 1\%, 5\%, and 10\% level respectively. See Appendix B for variable definitions. 
Table 13-B: Alternative Explanations - Threat of Entry

\begin{tabular}{|c|c|c|}
\hline \multirow[b]{2}{*}{ Variables } & \multicolumn{2}{|c|}{ Investment (=SGA+R\&D+CAPEX) } \\
\hline & (1) & $(2)$ \\
\hline IDD & $\begin{array}{c}-0.0164 * * \\
(-2.458)\end{array}$ & $\begin{array}{c}-0.020 * * * \\
(-3.407)\end{array}$ \\
\hline IDD $\times$ EntryThreat_HPP & $\begin{array}{c}-0.002 \\
(-0.354)\end{array}$ & \\
\hline IDD $\times$ EntryThreat_Investment & & $\begin{array}{c}-0.003 \\
(-0.365)\end{array}$ \\
\hline EntryThreat_HPP & $\begin{array}{c}0.0133 * * * \\
(4.040)\end{array}$ & \\
\hline EntryThreat_Investment & & $\begin{array}{c}0.062 * * * \\
(12.548)\end{array}$ \\
\hline Size & $\begin{array}{c}-0.291 * * * \\
(-23.45)\end{array}$ & $\begin{array}{c}-0.297 * * * \\
(-28.047)\end{array}$ \\
\hline Size-Squared & $\begin{array}{c}0.0116 * * * \\
(11.09)\end{array}$ & $\begin{array}{c}0.013 * * * \\
(14.355)\end{array}$ \\
\hline Age & $\begin{array}{c}0.0101 * * * \\
(18.49)\end{array}$ & $\begin{array}{c}0.009 * * * \\
(18.123)\end{array}$ \\
\hline Leverage & $\begin{array}{c}0.0936^{* * * *} \\
(7.819)\end{array}$ & $\begin{array}{c}0.139 * * * \\
(11.950)\end{array}$ \\
\hline InstOwn & $\begin{array}{c}-0.00506 \\
(-0.910)\end{array}$ & $\begin{array}{c}-0.001 \\
(-0.144)\end{array}$ \\
\hline \#Analyst & $\begin{array}{c}0.00325 * * * \\
(8.588)\end{array}$ & $\begin{array}{c}0.003 * * * \\
(6.698)\end{array}$ \\
\hline Loss & $\begin{array}{c}0.0754 * * * \\
(16.08)\end{array}$ & $\begin{array}{c}0.082 * * * \\
(17.085)\end{array}$ \\
\hline Equity & $\begin{array}{c}-0.000505 \\
(-0.246)\end{array}$ & $\begin{array}{c}0.007 * * * \\
(3.092)\end{array}$ \\
\hline EarnVol & $\begin{array}{l}0.0195 \\
(1.309)\end{array}$ & $\begin{array}{c}0.035^{* * *} * \\
(2.716)\end{array}$ \\
\hline $\mathrm{HHI}$ & $\begin{array}{c}-0.217 * * * \\
(-4.284)\end{array}$ & $\begin{array}{c}-0.349 * * * \\
(-6.219)\end{array}$ \\
\hline HHI-Squared & $\begin{array}{c}0.154 * * * \\
(2.818)\end{array}$ & $\begin{array}{c}0.196 * * * \\
(3.347)\end{array}$ \\
\hline Observations & 58,990 & 95,427 \\
\hline Adjusted R-squared & 0.757 & 0.723 \\
\hline Firm FE & Yes & Yes \\
\hline Year FE & Yes & Yes \\
\hline
\end{tabular}


The table tests whether changes in entry threat could explain the myopic underinvestment. EntryThreat_HPP takes one if a firm's fluidity (entry threat measure from Hoberg, Phillips, and Prabhala (2014)) is greater than the industry median, zero otherwise. EntryThreat_Investment takes one if a firm's total investments in SGA, R\&D, and CAPEX in the previous five years are greater than the industry-year median, zero otherwise. IDD (Inevitable Disclosure Doctrine) equals one for all fiscal years greater than or equal to the IDDadoption year for firms located in adopting states, and zero otherwise. The sample period ranges from 1994-2011. Test statistics (two-sided) based on robust standard errors clustered at the firm level are reported in parenthesis. Asterisks ***, **, and * indicate statistical significance at the 1\%, 5\%, and 10\% level respectively. See Appendix B for variable definitions. 
Table 13-C: Alternative Explanations - CEO Career Concerns

\begin{tabular}{|c|c|c|c|c|}
\hline \multirow[b]{2}{*}{ Variables } & \multicolumn{2}{|c|}{ \# of Annual Forecasts } & \multicolumn{2}{|c|}{ Investment $_{\mathrm{t}}(=\mathrm{SGA}+\mathrm{R} \& \mathrm{D}+\mathrm{CAPEX})$} \\
\hline & $(1)$ & $(2)$ & $(3)$ & $(4)$ \\
\hline IDD & $\begin{array}{c}0.228 * * * \\
(3.154)\end{array}$ & $\begin{array}{c}0.226^{* * *} \\
(3.119)\end{array}$ & $\begin{array}{l}-0.010 * * \\
(-2.049)\end{array}$ & $\begin{array}{l}-0.01 * * \\
(-2.092)\end{array}$ \\
\hline IDD $\times$ FiringPay_High & $\begin{array}{c}-0.076 \\
(-0.639)\end{array}$ & & $\begin{array}{c}-0.01 \\
(-1.219)\end{array}$ & \\
\hline IDD $\times$ ControlPay_High & & $\begin{array}{c}-0.053 \\
(-0.473)\end{array}$ & & $\begin{array}{c}-0.007 \\
(-0.940)\end{array}$ \\
\hline FiringPay_High & $\begin{array}{l}-0.133 * * \\
(-2.259)\end{array}$ & & $\begin{array}{c}0.006 \\
(1.287)\end{array}$ & \\
\hline ControlPay_High & & $\begin{array}{c}-0.065 \\
(-1.135)\end{array}$ & & $\begin{array}{c}0.001 \\
(0.149)\end{array}$ \\
\hline Size & $\begin{array}{c}-0.037 \\
(-0.354)\end{array}$ & $\begin{array}{l}-0.042 \\
(-0.398)\end{array}$ & $\begin{array}{c}-0.079 * * * \\
(-5.931)\end{array}$ & $\begin{array}{c}-0.079 * * * \\
(-5.862)\end{array}$ \\
\hline Size-Squared & $\begin{array}{c}0.017 * * \\
(2.154)\end{array}$ & $\begin{array}{c}0.017 * * \\
(2.199)\end{array}$ & $\begin{array}{l}-0.000 \\
(-0.198)\end{array}$ & $\begin{array}{l}-0.000 \\
(-0.256)\end{array}$ \\
\hline Age & $\begin{array}{c}0.055^{* * *} * \\
(10.741)\end{array}$ & $\begin{array}{c}0.052 * * * \\
(10.263)\end{array}$ & $\begin{array}{l}0.003 * * * \\
(5.383)\end{array}$ & $\begin{array}{c}0.003 * * * \\
(5.561)\end{array}$ \\
\hline Leverage & $\begin{array}{c}-0.356 * * * \\
(-2.738)\end{array}$ & $\begin{array}{c}-0.363 * * * \\
(-2.786)\end{array}$ & $\begin{array}{c}-0.048 * * * \\
(-3.299)\end{array}$ & $\begin{array}{c}-0.047 * * * \\
(-3.264)\end{array}$ \\
\hline InstOwn & $\begin{array}{c}0.187 * * * \\
(2.596)\end{array}$ & $\begin{array}{c}0.186^{* * * *} \\
(2.581)\end{array}$ & $\begin{array}{c}-0.020 * * * \\
(-3.570)\end{array}$ & $\begin{array}{c}-0.020 * * * \\
(-3.572)\end{array}$ \\
\hline \#Analyst & $\begin{array}{c}0.011 * * * \\
(2.695)\end{array}$ & $\begin{array}{l}0.011 * * * \\
(2.706)\end{array}$ & $\begin{array}{l}0.002 * * * \\
(5.422)\end{array}$ & $\begin{array}{c}0.002 * * * \\
(5.392)\end{array}$ \\
\hline Loss & $\begin{array}{c}-0.310 * * * \\
(-6.843)\end{array}$ & $\begin{array}{c}-0.308 * * * \\
(-6.799)\end{array}$ & $\begin{array}{c}0.052 * * * \\
(6.097)\end{array}$ & $\begin{array}{c}0.052 * * * \\
(6.096)\end{array}$ \\
\hline Equity & $\begin{array}{l}-0.024 \\
(-0.820)\end{array}$ & $\begin{array}{c}-0.023 \\
(-0.781)\end{array}$ & $\begin{array}{l}-0.005 * * \\
(-2.155)\end{array}$ & $\begin{array}{l}-0.005^{* *} \\
(-2.165)\end{array}$ \\
\hline EarnVol & $\begin{array}{c}-0.530 * * \\
(-2.508)\end{array}$ & $\begin{array}{c}-0.527 * * \\
(-2.499)\end{array}$ & $\begin{array}{c}0.037 \\
(0.698)\end{array}$ & $\begin{array}{c}0.036 \\
(0.696)\end{array}$ \\
\hline HHI & $\begin{array}{l}-1.468 * * \\
(-2.547)\end{array}$ & $\begin{array}{l}-1.457 * * \\
(-2.522)\end{array}$ & $\begin{array}{c}-0.161 * * * \\
(-2.992)\end{array}$ & $\begin{array}{c}-0.161 * * * \\
(-2.985)\end{array}$ \\
\hline HHI-Squared & $\begin{array}{l}1.296 * \\
(1.914)\end{array}$ & $\begin{array}{l}1.289 * \\
(1.900)\end{array}$ & $\begin{array}{c}0.163 * * * \\
(2.957)\end{array}$ & $\begin{array}{c}0.162 * * * \\
(2.953)\end{array}$ \\
\hline Observations & 26,637 & 26,637 & 26,637 & 26,637 \\
\hline Adjusted R-squared & 0.413 & 0.413 & 0.850 & 0.850 \\
\hline Firm FE & Yes & Yes & Yes & Yes \\
\hline Year FE & Yes & Yes & Yes & Yes \\
\hline
\end{tabular}


The table tests whether CEO career concerns (independent of earnings guidance) could explain the observed underinvestment in Table 3 independent of management forecasts. FiringPay_High (ControlPay_High) takes one if the amount of payment CEO receives (scaled by firm's year-end market capitalization) in the event of involuntary termination (change of control) is higher than the Fama-French 48 industry-year median, with the assumption that CEO career concern should be less prominent for CEOs who are costlier to fire. IDD (Inevitable Disclosure Doctrine) equals one for all fiscal years greater than or equal to the IDDadoption year for firms located in adopting states, and zero otherwise. The sample period ranges from 1994-2011 and includes all Compustat-ExecuComp matched sample. Test statistics (two-sided) based on robust standard errors clustered at the firm level are reported in parenthesis. Asterisks ***, **, and * indicate statistical significance at the $1 \%, 5 \%$, and $10 \%$ level respectively. 
Table 13-D1: Alternative Explanations - Investment Opportunity Decreases

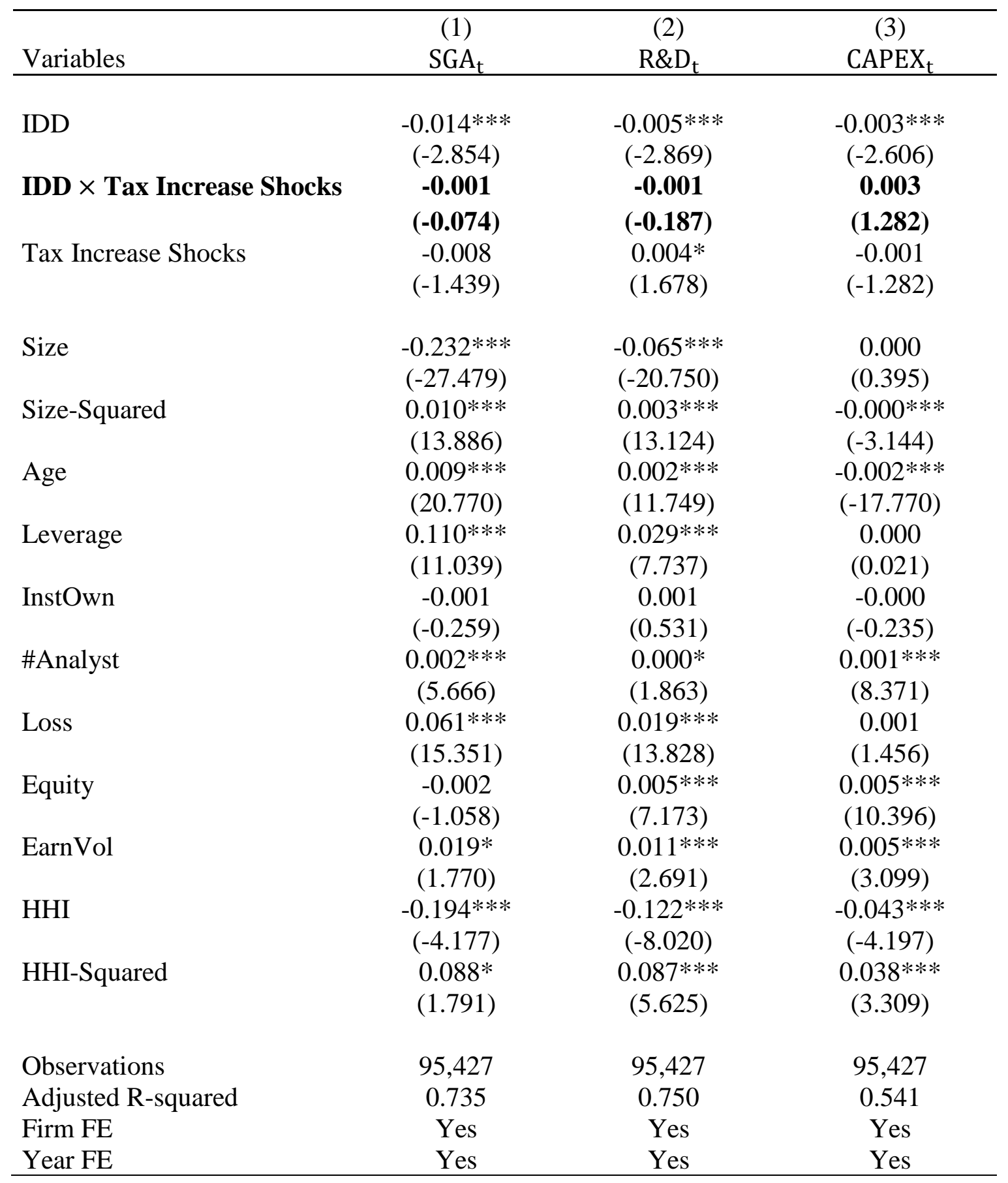


The table examines the sensitivity of investments to IDD conditional on exogenous decreases in investment opportunities (Tax Increase Shocks). Tax Increase Shocks is an indicator variable that takes one if the state where a firm is located increases tax and zero otherwise. IDD (Inevitable Disclosure Doctrine) equals one for all fiscal years greater than or equal to the IDDadoption year for firms located in adopting states, and zero otherwise. SGA, R\&D, CAPEX are the selling, general, admin and advertising expenses, research and development expenditures and capital expenditures respectively, scaled by the book value of assets. The sample period ranges from 1994-2011. All specifications are estimated using the OLS regression. Test statistics (two-sided) based on robust standard errors clustered at the firm level are reported in parenthesis. Asterisks $* * *, * *$, and $*$ indicate statistical significance at the $1 \%$, $5 \%$, and $10 \%$ level respectively. 
Table 13-D2: Alternative Explanations - Investment Opportunity Increases

\begin{tabular}{|c|c|c|c|}
\hline Variables & $\begin{array}{r}(1) \\
S_{G A} \\
\end{array}$ & $\begin{array}{c}(2) \\
R \& D_{t} \\
\end{array}$ & $\begin{array}{c}(3) \\
\text { CAPEX }_{\mathrm{t}} \\
\end{array}$ \\
\hline IDD & $\begin{array}{c}-0.014 * * * \\
(-2.696)\end{array}$ & $\begin{array}{c}-0.005 * * * \\
(-2.800)\end{array}$ & $\begin{array}{c}-0.003 * * \\
(-2.372)\end{array}$ \\
\hline IDD $\times$ Tax Decrease Shocks & $\begin{array}{c}-0.005 \\
(-0.545)\end{array}$ & $\begin{array}{c}-0.002 \\
(-0.584)\end{array}$ & $\begin{array}{c}-0.002 \\
(-0.933)\end{array}$ \\
\hline Tax Decrease Shocks & $\begin{array}{c}0.004 \\
(0.967)\end{array}$ & $\begin{array}{c}0.001 \\
(0.403)\end{array}$ & $\begin{array}{c}0.003 * * * \\
(2.695)\end{array}$ \\
\hline Size & $\begin{array}{c}-0.232 * * * \\
(-27.487)\end{array}$ & $\begin{array}{c}-0.065 * * * \\
(-20.749)\end{array}$ & $\begin{array}{c}0.000 \\
(0.391)\end{array}$ \\
\hline Size-Squared & $\begin{array}{c}0.010 * * * \\
(13.889)\end{array}$ & $\begin{array}{c}0.003 * * * \\
(13.120)\end{array}$ & $\begin{array}{c}-0.000 * * * \\
(-3.150)\end{array}$ \\
\hline Age & $\begin{array}{c}0.009 * * * \\
(20.818)\end{array}$ & $\begin{array}{c}0.002 * * * \\
(11.839)\end{array}$ & $\begin{array}{c}-0.002 * * * \\
(-17.578)\end{array}$ \\
\hline Leverage & $\begin{array}{c}0.110 * * * \\
(11.039)\end{array}$ & $\begin{array}{c}0.029 * * * \\
(7.734)\end{array}$ & $\begin{array}{c}0.000 \\
(0.023)\end{array}$ \\
\hline InstOwn & $\begin{array}{c}-0.001 \\
(-0.254)\end{array}$ & $\begin{array}{c}0.001 \\
(0.513)\end{array}$ & $\begin{array}{c}-0.000 \\
(-0.250)\end{array}$ \\
\hline \#Analyst & $\begin{array}{c}0.002 * * * \\
(5.670)\end{array}$ & $\begin{array}{l}0.000 * \\
(1.873)\end{array}$ & $\begin{array}{c}0.001 * * * \\
(8.386)\end{array}$ \\
\hline Loss & $\begin{array}{c}0.061 * * * \\
(15.341)\end{array}$ & $\begin{array}{c}0.019 * * * \\
(13.838)\end{array}$ & $\begin{array}{c}0.001 \\
(1.435)\end{array}$ \\
\hline Equity & $\begin{array}{c}-0.002 \\
(-1.054)\end{array}$ & $\begin{array}{c}0.005^{* * *} * \\
(7.178)\end{array}$ & $\begin{array}{c}0.005 \text { *** } \\
(10.418)\end{array}$ \\
\hline EarnVol & $\begin{array}{l}0.019 * \\
(1.768)\end{array}$ & $\begin{array}{c}0.011 * * * \\
(2.694)\end{array}$ & $\begin{array}{c}0.005 * * * \\
(3.090)\end{array}$ \\
\hline HHI & $\begin{array}{c}-0.194 * * * \\
(-4.179)\end{array}$ & $\begin{array}{c}-0.122 * * * \\
(-8.012)\end{array}$ & $\begin{array}{c}-0.043 * * * \\
(-4.183)\end{array}$ \\
\hline HHI-Squared & $\begin{array}{l}0.088 * \\
(1.791)\end{array}$ & $\begin{array}{c}0.086 * * * \\
(5.610)\end{array}$ & $\begin{array}{c}0.038 * * * \\
(3.285)\end{array}$ \\
\hline Observations & 95,427 & 95,427 & 95,427 \\
\hline Adjusted R-squared & 0.735 & 0.541 & 0.750 \\
\hline Firm FE & Yes & Yes & Yes \\
\hline Year FE & Yes & Yes & Yes \\
\hline
\end{tabular}


The table examines the sensitivity of investments to IDD conditional on exogenous increases in investment opportunities (Tax Decrease Shocks). Tax Decrease Shock) is an indicator variable that takes one if the state where a firm is located decreases tax and zero otherwise. IDD (Inevitable Disclosure Doctrine) equals one for all fiscal years greater than or equal to the IDD-adoption year for firms located in adopting states, and zero otherwise. SGA, R\&D, CAPEX are the selling, general, admin and advertising expenses, research and development expenditures and capital expenditures respectively, scaled by the book value of assets. The sample period ranges from 1994-2011. All specifications are estimated using the OLS regression. Test statistics (two-sided) based on robust standard errors clustered at the firm level are reported in parenthesis. Asterisks $* * *, * *$, and $*$ indicate statistical significance at the $1 \%$, $5 \%$, and $10 \%$ level respectively. 
Table 14: Sensitivity of Inferences to Potentially Endogenous Control Variables

\begin{tabular}{|c|c|c|c|}
\hline \multirow[b]{3}{*}{ Variables } & \multicolumn{3}{|c|}{ 2SLS $2^{\text {nd }}$ Stage (Instrument is IDD) } \\
\hline & (1) & $(2)$ & (3) \\
\hline & $\mathrm{SGA}_{\mathrm{t}}$ & $\mathrm{R} \& \mathrm{D}_{\mathrm{t}}$ & CAPEX $_{\mathrm{t}}$ \\
\hline \# of Annual Forecasts & $\begin{array}{c}-0.106 * * \\
(-2.472)\end{array}$ & $\begin{array}{c}-0.036 * * \\
(-2.552)\end{array}$ & $\begin{array}{c}-0.027 * * \\
(-2.331)\end{array}$ \\
\hline Size & $\begin{array}{c}-0.256 * * * \\
(-17.471)\end{array}$ & $\begin{array}{c}-0.073 * * * \\
(-14.266)\end{array}$ & $\begin{array}{c}-0.007 * * \\
(-2.204)\end{array}$ \\
\hline Size-Squared & $\begin{array}{c}0.016^{* * *} \\
(6.421)\end{array}$ & $\begin{array}{c}0.005 * * * \\
(6.181)\end{array}$ & $\begin{array}{c}0.001 * * \\
(2.060)\end{array}$ \\
\hline Age & $\begin{array}{c}0.010 * * * \\
(16.189)\end{array}$ & $\begin{array}{c}0.002 * * * \\
(9.806)\end{array}$ & $\begin{array}{c}-0.001 * * * \\
(-8.722)\end{array}$ \\
\hline Other Controls & No & No & No \\
\hline Observations & 95,427 & 95,427 & 95,427 \\
\hline Adjusted R-squared & 0.102 & 0.037 & 0.006 \\
\hline Firm \& Year FE & Yes & Yes & Yes \\
\hline First-Stage F-Stat & 13.492 & 13.492 & 13.492 \\
\hline
\end{tabular}


The table tests the sensitivity of 2SLS estimates reported in Table 4 to the exclusion of timevarying control variables that could themselves potentially be affected by the state adoption of IDD. SGA, R\&D, CAPEX are the selling, general, admin and advertising expenses, research and development expenditures and capital expenditures respectively, scaled by the book value of assets. IDD (Inevitable Disclosure Doctrine) is used as an instrument for annual earnings guidance (see Table 3 for first-stage). IDD equals one for all fiscal years greater than or equal to the IDD-adoption year for firms located in adopting states, and zero otherwise. Test statistics (two-sided) based on robust standard errors clustered at the firm level are reported in parenthesis. Asterisks ***,**, and * indicate statistical significance at the $1 \%, 5 \%$, and $10 \%$ level respectively. See Appendix B for variable definitions. 
Table 15: Sensitivity of Inferences to Industry and Local Economic Shocks

\begin{tabular}{|c|c|c|c|}
\hline \multirow[b]{3}{*}{ Variables } & \multicolumn{3}{|c|}{ 2SLS $2^{\text {nd }}$ Stage (Instrument is IDD) } \\
\hline & (1) & $(2)$ & (3) \\
\hline & $\mathrm{SGA}_{\mathrm{t}}$ & $\mathrm{R} \& \mathrm{D}_{\mathrm{t}}$ & CAPEX $_{t}$ \\
\hline \# of Annual Forecasts & $\begin{array}{c}-0.104 * * \\
(-2.405)\end{array}$ & $\begin{array}{c}-0.031 * * \\
(-2.271)\end{array}$ & $\begin{array}{l}-0.018 * \\
(-1.753)\end{array}$ \\
\hline Size & $\begin{array}{c}-0.253 * * * \\
(-16.206)\end{array}$ & $\begin{array}{c}-0.071 * * * \\
(-13.734)\end{array}$ & $\begin{array}{c}-0.005 \\
(-1.474)\end{array}$ \\
\hline Size-Squared & $\begin{array}{c}0.014 * * * \\
(6.687)\end{array}$ & $\begin{array}{c}0.005^{* * * *} \\
(6.676)\end{array}$ & $\begin{array}{c}0.001 \\
(1.092)\end{array}$ \\
\hline Age & $\begin{array}{c}0.001 \\
(1.556)\end{array}$ & $\begin{array}{c}-0.002 * * * \\
(-9.517)\end{array}$ & $\begin{array}{c}-0.001 * * * \\
(-2.906)\end{array}$ \\
\hline Leverage & $\begin{array}{c}0.077 * * * \\
(6.491)\end{array}$ & $\begin{array}{c}0.018 * * * \\
(4.548)\end{array}$ & $\begin{array}{c}-0.004 \\
(-1.372)\end{array}$ \\
\hline InstOwn & $\begin{array}{c}0.049 * * \\
(2.090)\end{array}$ & $\begin{array}{c}0.016^{* *} * \\
(2.162)\end{array}$ & $\begin{array}{c}0.009 \\
(1.571)\end{array}$ \\
\hline \#Analyst & $\begin{array}{c}0.004 * * * \\
(3.712)\end{array}$ & $\begin{array}{c}0.001 * * \\
(2.559)\end{array}$ & $\begin{array}{c}0.001 * * * \\
(4.082)\end{array}$ \\
\hline Loss & $\begin{array}{c}0.049 * * * \\
(7.438)\end{array}$ & $\begin{array}{c}0.016^{* * * *} \\
(7.389)\end{array}$ & $\begin{array}{c}-0.001 \\
(-0.951)\end{array}$ \\
\hline Equity & $\begin{array}{c}-0.005 * * \\
(-2.107)\end{array}$ & $\begin{array}{c}0.004 * * * \\
(5.298)\end{array}$ & $\begin{array}{c}0.005^{* * * *} \\
(8.528)\end{array}$ \\
\hline EarnVol & $\begin{array}{c}0.011 \\
(1.008)\end{array}$ & $\begin{array}{c}0.011 * * \\
(2.518)\end{array}$ & $\begin{array}{c}0.004 * * \\
(2.467)\end{array}$ \\
\hline HHI & $\begin{array}{c}-0.140 * * * \\
(-3.006)\end{array}$ & $\begin{array}{c}-0.101 * * * \\
(-6.810)\end{array}$ & $\begin{array}{c}-0.040 * * * \\
(-3.724)\end{array}$ \\
\hline HHI-Squared & $\begin{array}{c}0.108 * * \\
(2.052)\end{array}$ & $\begin{array}{c}0.084 * * * \\
(5.139)\end{array}$ & $\begin{array}{c}0.043^{* * *} \\
(3.456)\end{array}$ \\
\hline State-Year Shocks & $\begin{array}{c}-0.039 \\
(-0.814)\end{array}$ & $\begin{array}{c}0.096^{* * *} * \\
(2.645)\end{array}$ & $\begin{array}{c}0.230 * * * \\
(6.729)\end{array}$ \\
\hline Firm FE & Yes & Yes & Yes \\
\hline Industry $\times$ Year FE & Yes & Yes & Yes \\
\hline Observations & 94,131 & 94,131 & 94,131 \\
\hline Adjusted R-squared & 0.204 & 0.099 & 0.011 \\
\hline First-Stage F-Stat & 12.741 & 12.893 & 13.286 \\
\hline
\end{tabular}


The table tests the sensitivity of 2SLS estimates reported in Table 4 to the time-varying industry conditions and local state-specific shocks. SGA, R\&D, CAPEX are the selling, general, admin and advertising expenses, research and development expenditures and capital expenditures respectively, scaled by the book value of assets. IDD (Inevitable Disclosure Doctrine) is used as an instrument for annual earnings guidance (see Table 3 for first-stage). IDD equals one for all fiscal years greater than or equal to the IDD-adoption year for firms located in adopting states, and zero otherwise. The State-Year Shocks are included to control for local economic shocks and calculated as the average of SGA, R\&D, and CAPEX respectively for all firms in a state for the fiscal year, except the firm itself. Test statistics (twosided) based on robust standard errors clustered at the firm level are reported in parenthesis. Asterisks $* * *, * *$, and * indicate statistical significance at the $1 \%, 5 \%$, and $10 \%$ level respectively. See Appendix B for variable definitions. 
Table 16: Earnings Guidance and Accruals Earnings Management

\begin{tabular}{|c|c|c|c|c|}
\hline \multirow[b]{2}{*}{ Variables } & \multicolumn{2}{|c|}{ OLS } & \multicolumn{2}{|c|}{ 2SLS (Instrument is IDD) } \\
\hline & $\begin{array}{c}(1) \\
\text { DAC }\end{array}$ & $\begin{array}{c}(2) \\
\text { TAC } \\
\end{array}$ & $\begin{array}{c}(3) \\
\text { DAC }\end{array}$ & $\begin{array}{c}(4) \\
\text { TAC }\end{array}$ \\
\hline $\begin{array}{l}\text { \# of Numerical Annual } \\
\text { Forecasts }\end{array}$ & $\begin{array}{l}-0.0008 * \\
(-1.765)\end{array}$ & $\begin{array}{l}-0.0009 \\
(-0.158)\end{array}$ & $\begin{array}{l}-0.0044 \\
(-0.178)\end{array}$ & $\begin{array}{l}0.0197 \\
(0.542)\end{array}$ \\
\hline Size & $\begin{array}{c}-0.0618^{* * *} \\
(-13.98)\end{array}$ & $\begin{array}{c}0.00192 \\
(0.301)\end{array}$ & $\begin{array}{c}-0.0625 * * * \\
(-9.168)\end{array}$ & $\begin{array}{c}0.00632 \\
(0.633)\end{array}$ \\
\hline Size-Squared & $\begin{array}{c}0.00339 * * * \\
(9.329)\end{array}$ & $\begin{array}{c}-0.000846 \\
(-1.616)\end{array}$ & $\begin{array}{c}0.00351 * * * \\
(3.871)\end{array}$ & $\begin{array}{c}-0.00153 \\
(-1.144)\end{array}$ \\
\hline Age & $\begin{array}{l}0.00187 * * * \\
(6.939)\end{array}$ & $\begin{array}{c}-0.000297 \\
(-0.794)\end{array}$ & $\begin{array}{l}0.00191 * * * \\
(4.910)\end{array}$ & $\begin{array}{c}-0.000518 \\
(-0.930)\end{array}$ \\
\hline Leverage & $\begin{array}{c}0.0141^{*} \\
(1.935)\end{array}$ & $\begin{array}{c}-0.0795 * * * \\
(-7.612)\end{array}$ & $\begin{array}{c}0.0137 * \\
(1.814)\end{array}$ & $\begin{array}{c}-0.0769 * * * \\
(-7.009)\end{array}$ \\
\hline InstOwn & $\begin{array}{c}0.0132 * * * \\
(3.516)\end{array}$ & $\begin{array}{c}0.0189 * * * \\
(3.798)\end{array}$ & $\begin{array}{l}0.0145 \\
(1.451)\end{array}$ & $\begin{array}{l}0.0113 \\
(0.763)\end{array}$ \\
\hline \#Analyst & $\begin{array}{c}0.000524 * * \\
(2.502)\end{array}$ & $\begin{array}{c}0.00125^{* * * *} \\
(4.485)\end{array}$ & $\begin{array}{c}0.000570 \\
(1.427)\end{array}$ & $\begin{array}{c}0.000971 * \\
(1.697)\end{array}$ \\
\hline Loss & $\begin{array}{c}-0.0595^{* * *} \\
(-18.91)\end{array}$ & $\begin{array}{c}-0.134 * * * \\
(-30.38)\end{array}$ & $\begin{array}{c}-0.0598 * * * \\
(-16.27)\end{array}$ & $\begin{array}{c}-0.132 * * * \\
(-25.06)\end{array}$ \\
\hline Equity & $\begin{array}{c}0.00778 * * * \\
(5.028)\end{array}$ & $\begin{array}{c}-0.00859 * * * \\
(-4.114)\end{array}$ & $\begin{array}{c}0.00775 * * * \\
(5.327)\end{array}$ & $\begin{array}{c}-0.00845 * * * \\
(-4.260)\end{array}$ \\
\hline EarnVol & $\begin{array}{c}-0.0498 * * * \\
(-5.934)\end{array}$ & $\begin{array}{c}-0.185 * * * \\
(-13.39)\end{array}$ & $\begin{array}{c}-0.0499 * * * \\
(-6.338)\end{array}$ & $\begin{array}{c}-0.184 * * * \\
(-14.19)\end{array}$ \\
\hline HHI & $\begin{array}{c}0.00529 \\
(0.176)\end{array}$ & $\begin{array}{l}0.0328 \\
(0.763)\end{array}$ & $\begin{array}{c}0.00398 \\
(0.134)\end{array}$ & $\begin{array}{l}0.0406 \\
(0.943)\end{array}$ \\
\hline HHI-Squared & $\begin{array}{l}-0.00745 \\
(-0.217)\end{array}$ & $\begin{array}{l}-0.00190 \\
(-0.0397)\end{array}$ & $\begin{array}{l}-0.00575 \\
(-0.167)\end{array}$ & $\begin{array}{l}-0.0119 \\
(-0.246)\end{array}$ \\
\hline Observations & 94,540 & 94,540 & 94,540 & 94,540 \\
\hline Adjusted R-squared & 0.176 & 0.344 & 0.168 & 0.164 \\
\hline Firm \& Year FE & Yes & Yes & Yes & Yes \\
\hline F-Stat & N/A & N/A & 15.003 & 15.003 \\
\hline
\end{tabular}


The table reports the OLS and 2SLS estimates for the effect of annual earnings guidance on accrual-based earnings management. Columns 3-4 use IDD as an instrument for annual earnings guidance (see Table 2 for the first-stage). IDD (Inevitable Disclosure Doctrine) equals one for all fiscal years greater than or equal to the IDD-adoption year for firms located in adopting states, and zero otherwise. DAC (TAC) stands for discretionary accruals (total accruals). DAC is calculated using performance-adjusted model by Kothari, Leone, Wasley (2005) and TAC is income before extraordinary items minus operating cash flows, scaled by lagged book assets. Test statistics (two-sided) based on robust standard errors clustered at the firm level are reported in parenthesis. Asterisks $* * *, * *$, and * indicate statistical significance at the $1 \%, 5 \%$, and $10 \%$ level respectively. See appendix B for variable definitions. 